RERFIVED

JUL $0>2000$

OSनI

\title{
Effect of Daily Fluctuations from Flaming Gorge Dam on Ice Processes in the Green River
}
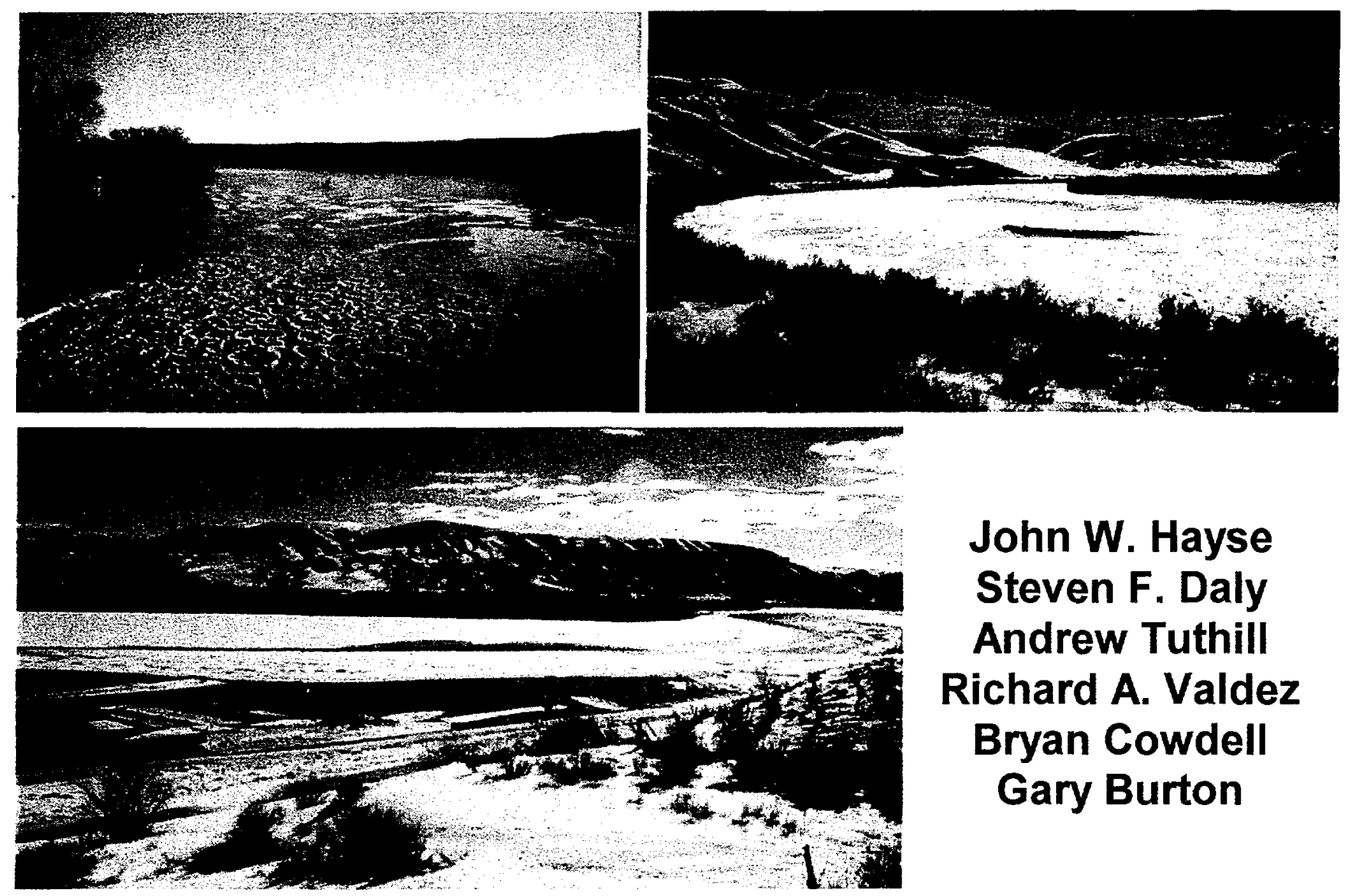

Upper Colorado River

Endangered Fish

Recovery Program

Project \#83
John W. Hayse Steven F. Daly Andrew Tuthill Richard A. Valdez Bryan Cowdell Gary Burton
Final Report

May 2000 
Argonne National Laboratory, with facilities in the states of Illinois and Idaho, is owned by the United States government, and operated by The University of Chicago under the provisions of a contract with the Department of Energy.

\section{DISCLAIMER}

This report was prepared as an account of work sponsored by an agency of the United States Government. Neither the United States Government nor any agency thereof, nor The University of Chicago, nor any of their employees or officers, makes any warranty, express or implied, or assumes any legal liability or responsibility for the accuracy, completeness, or usefulness of any information, apparatus, product, or process disclosed, or represents that its use would not infringe privately owned rights. Reference herein to any specific commercial product, process, or service by trade name, trademark, manufacturer, or otherwise, does not necessarily constitute or imply its endorsement, recommendation, or favoring by the United States Government or any agency thereof. The views and opinions of document authors expressed herein do not necessarily state or reflect those of the United States Government or any agency thereof, Argonne National Laboratory, or The University of Chicago.

Available electronically at http://www.doe.gov/bridge

Available for a processing fee to U.S. Department of

Energy and its contractors, in paper, from:

U.S. Department of Energy

Office of Scientific and Technical Information

P.O. Box 62

Oak Ridge, TN 37831-0062

phone: (865) 576-8401

fax: (865) $576-5728$

e-mail: reports@adonis.osti.gov

Argonne National Laboratory Report No. ANL/EA/RP-102041 


\title{
EFFECT OF DAILY FLUCTUATIONS FROM FLAMING GORGE DAM ON ICE PROCESSES IN THE GREEN RIVER
}

Upper Colorado River Recovery Program Project No. 83

Final Report

John W. Hayse', Steven F. Daly' ${ }^{2}$, Andrew Tuthill², Richard A. Valdez ${ }^{3,4}$, Bryan Cowdell ${ }^{3}$, and Gary Burton ${ }^{5}$

\author{
'Argonne National Laboratory \\ Environmental Assessment Division \\ 9700 South Cass Avenue \\ Argonne, Illinois 60439
}

${ }^{2}$ U.S. Army Corps of Engineers Research and Development Center Cold Regions Research and Engineering Laboratory

72 Lyme Road

Hanover, New Hampshire 03755

${ }^{3} \mathrm{BIO} / \mathrm{WEST}$, Inc.

1063 West 1400 North

Logan, Utah 84321

$\left({ }^{4}\right.$ Current address: SWCA, Inc.; 56 West 400 South; Suite 201; Salt Lake City, Utah 84101)

\author{
${ }^{5}$ Western Area Power Administration \\ P.O. Box 3402 \\ Golden, Colorado 80401
}




\section{ACKNOWLEDGMENTS}

This report was funded, in part, by the Recovery Implementation Program for the Endangered Fish Species in the Upper Colorado River Basin (Recovery Program). The Recovery Program is a joint effort of the U.S. Fish and Wildlife Service, U.S. Bureau of Reclamation, Western Area Power Administration, the states of Colorado, Utah, and Wyoming, Upper Basin water users, environmental organizations, and the Colorado River Energy Distributors Association. This project was completed through a cooperative effort among researchers from Argonne National Laboratory, the U.S. Army Cold Regions Research and Engineering Laboratory, BIO/WEST, and Western Area Power Administration.

We thank Steve Petersburg of the National Park Service, Dinosaur National Monument for granting a scientific research permit and Steven Brock and Daniel Schaad of the Ouray National Wildlife Refuge for their cooperation with providing the appropriate permits and access to roads and other areas at the refuge. In addition, the authors thank Tom Ryan of the U.S. Bureau of Reclamation for providing timely output from hydrological modeling that allowed us to coordinate field work at downstream locations with water releases from Flaming Gorge Dam. 


\section{DISCLAIMER}

Portions of this document may be illegible in electronic image products. Images are produced from the best available original document. 


\section{TABLE OF CONTENTS}

ACKNOWLEDGMENTS $\ldots \ldots \ldots \ldots \ldots \ldots \ldots \ldots \ldots \ldots \ldots \ldots \ldots \ldots$ ii

LIST OF TABLES $\ldots \ldots \ldots \ldots \ldots \ldots \ldots \ldots \ldots \ldots \ldots \ldots \ldots \ldots \ldots \ldots$

LIST OF FIGURES $\ldots \ldots \ldots \ldots \ldots \ldots \ldots \ldots \ldots \ldots \ldots \ldots \ldots \ldots \ldots \ldots \ldots \ldots$

LIST OF KEY WORDS $\ldots \ldots \ldots \ldots \ldots \ldots \ldots \ldots \ldots \ldots \ldots \ldots \ldots \ldots$ ix

EXECUTIVE SUMMARY $\ldots \ldots \ldots \ldots \ldots \ldots \ldots \ldots \ldots \ldots \ldots \ldots \ldots \ldots$

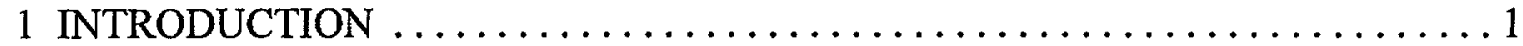

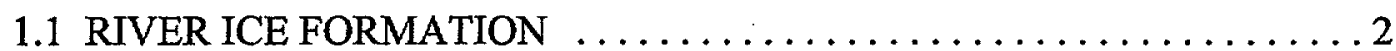

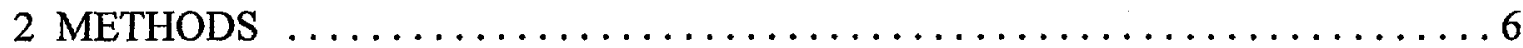

2.1 THE STUDY REACH $\ldots \ldots \ldots \ldots \ldots \ldots \ldots \ldots \ldots \ldots \ldots \ldots \ldots \ldots \ldots \ldots \ldots$

2.2 HISTORICAL CONDITIONS AND OBSERVATIONS $\ldots \ldots \ldots \ldots \ldots$

2.2.1 Flow Rates $\ldots \ldots \ldots \ldots \ldots \ldots \ldots \ldots \ldots \ldots \ldots \ldots \ldots \ldots \ldots \ldots \ldots$

2.2.2 Water and Air Temperature Measurements .......... 7

2.2.3 Historical Ice Observations $\ldots \ldots \ldots \ldots \ldots \ldots \ldots \ldots \ldots$

2.319961997 FIELD MEASUREMENTS . . . . . . . . . . . . . . . . 8

2.4 ICE PROCESS MODELING $\ldots \ldots \ldots \ldots \ldots \ldots \ldots \ldots \ldots$

2.4.1 Unsteady Flow Sub-Model $\ldots \ldots \ldots \ldots \ldots \ldots$

2.4.1.1 Channel Geometry Data . . . . . . . . . . . 11

2.4.1.2 Calibration of UNET Unsteady Flow Model . . . . . . 11

2.4.2 Transport Sub-Model . . . . . . . . . . . . . 13

2.4.3 Ice Cover Progression Sub-Model . . . . . . . . . . . . 13

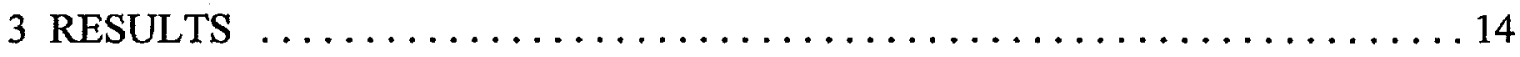

3.1 HISTORICAL CONDITIONS AND OBSERVATIONS $\ldots \ldots \ldots \ldots \ldots$

3.1 .1 Winter Flows $\ldots \ldots \ldots \ldots \ldots \ldots \ldots \ldots \ldots \ldots \ldots \ldots \ldots \ldots \ldots$

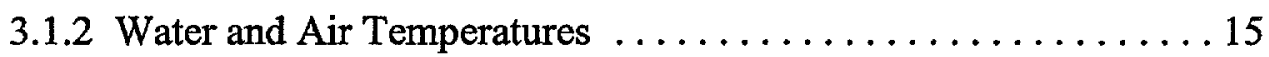

3.1 .3 Ice Formation on the Green River $\ldots \ldots \ldots \ldots \ldots$

3.1.3.1 USGS Observations $\ldots \ldots \ldots \ldots \ldots \ldots \ldots \ldots \ldots$

3.1.3.2 BIO/WEST Reports $\ldots \ldots \ldots \ldots \ldots \ldots \ldots$ 
3.1.3.3 Winter of 1996-97 Field Survey $\ldots \ldots \ldots \ldots \ldots 17$

3.2 1996-1997 FIELD MEASUREMENTS . . . . . . . . . . . . . . 19

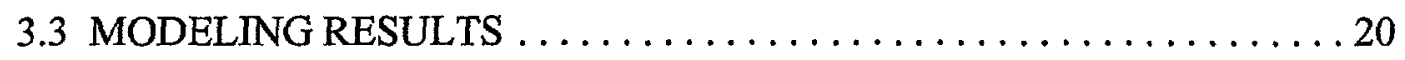

3.4 RIVER HYDRAULIC CONDITIONS: COMPARISON OF

STEADY AND UNSTEADY FLOWS $\ldots \ldots \ldots \ldots \ldots \ldots \ldots \ldots \ldots$

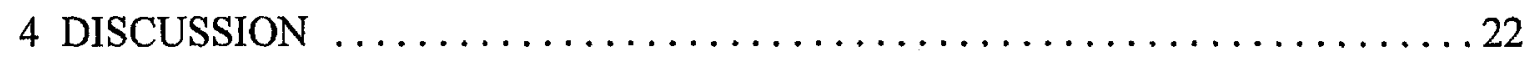

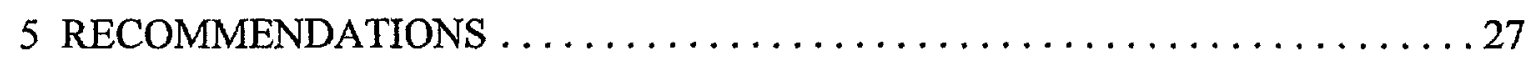

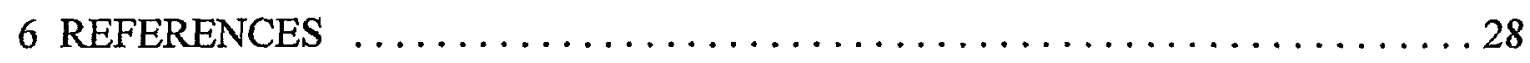

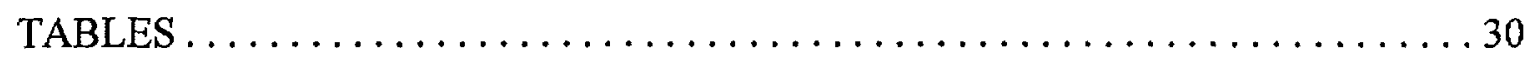

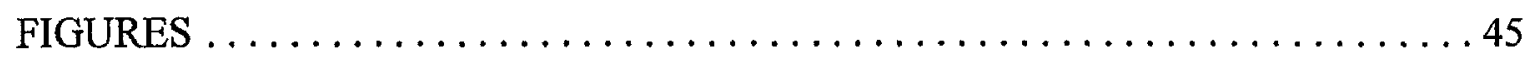

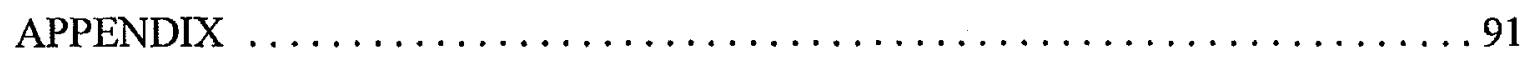




\section{LIST OF TABLES}

Table 1. Calibration data used in the unsteady flow UNET model .31

Table 2. Maximum accumulated freezing degrees days (AFDD) for water years 1950 to 1997 34

Table 3. Field survey observations of ice conditions on 18-19 December 1996 . . . . 36

Table 4. Ice thickness measurements before and after initiation of peaking flows . . 337

Table 5. Results of two-way analysis of variance (ANOVA) to evaluate the effects of cross section location (river mile, RM) and fluctuation regime (steady flow vs. fluctuating flow) on ice cover thickness. . . . . . . . . 38

Table 6. Stage, velocity, depth and Froude number for a steady flow of $2400 \mathrm{cfs}$. . . . 39

Table 7. Stage, velocity, depth, and Froude number at first peak following the steady flow period

Table 8. Stage, velocity, depth, and Froude number at first trough following initial peak

Table 9. Stage, velocity, depth and Froude number at lowest trough $\ldots \ldots \ldots \ldots 42$

Table 10. Stage, velocity, depth and Froude number at highest peak .......... 43

Table 11. Maximum AFDD, mean daily winter flow, maximum reported upstream ice cover extent, and the daily release schedule during ice observations in the study area .44 


\section{LIST OF FIGURES}

Figure 1. Map of the Green River basin $\ldots \ldots \ldots \ldots \ldots \ldots \ldots \ldots \ldots \ldots \ldots \ldots \ldots \ldots \ldots \ldots$

Figure 2. Map of the study area in the Green River $\ldots \ldots \ldots \ldots \ldots \ldots \ldots \ldots$

Figure 3. Locations of cross sections for stage change and ice thickness measurements ........................... 48

Figure 4. Stage-discharge curve for the Jensen, Utah gage . . . . . . . . . . . . . 49

Figure 5. Stage-discharge curve for the Ouray, Utah bridge . . . . . . . . . 50

Figure 6. Graphical representation of cross section locations and types $\ldots \ldots \ldots 51$

Figure 7. Measured stage at the Chew Bridge (RM 316) and reported stage from

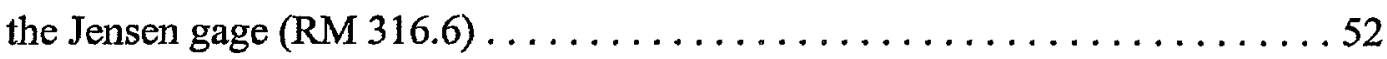

Figure 8. Simulated and measured hydrograph at Dinosaur Bend (RM 307) . . . . . 53

Figure 9. Simulated and measured stage for the Jensen Bridge (RM 302.3) . . . . . 54

Figure 10. Simulated and measured stage at Bonanza Bridge (RM 290.4) . . . . . 55

Figure 11. Simulated and measured stage at Horseshoe Bend (RM 279.0) . . . . . 56

Figure 12. Simulated and measured stage at the Ouray National Wildlife Refuge

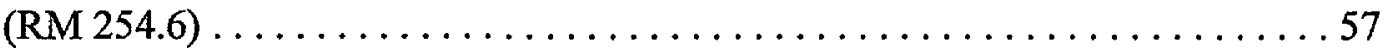

Figure 13. Simulated and measured stage at the Ouray Bridge (RM 248.0) .....58

Figure 14. Mean daily discharge at the Greendale gage for pre-dam and post-dam

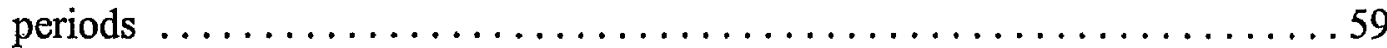

Figure 15. Mean daily discharge at the Jensen gage for pre-dam and post-dam

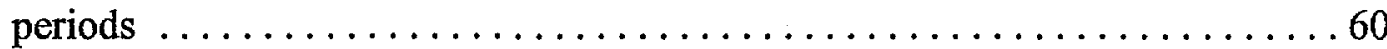

Figure 16. Mean daily discharge at the Jensen, Utah gage during the winter period (November through March) for the pre-dam years of record

Figure 17. Mean daily discharge at the Jensen, Utah gage during the winter period (November through March) for the post-dam years of record

Figure 18. Hourly releases from Flaming Gorge Dam and hourly flows reported for the Jensen gage for 15-31 January 1997, showing the steady flow and peaking flow periods

Figure 19. Mean daily air temperatures for Vernal, Utah from November through 
April based on records from $1945-1997 \ldots \ldots \ldots \ldots \ldots \ldots \ldots \ldots . \ldots 64$

Figure 20. Maximum accumulated freezing degree days (AFDD) for 1950-1997 . . . 65

Figure 21. Water temperatures for Flaming Gorge Dam (FGD) releases and the Green River at the Jensen gage, air temperature for Vernal, Utah, and mean daily flow at the Jensen gage during the winter of $1989-1990 \ldots \ldots \ldots \ldots 66$

Figure 22. Water temperatures for Flaming Gorge Dam (FGD) releases and the Green River at the Jensen gage, air temperature for Vernal, Utah, and mean daily flow at the Jensen gage during the winter of $1990-1991 \ldots \ldots \ldots \ldots 67$

Figure 23. Water temperatures for Flaming Gorge Dam (FGD) releases and the Green River at the Jensen gage, air temperature for Vernal, Utah, and mean daily flow at the Jensen gage during the winter of 1991-1992 $\ldots \ldots \ldots \ldots 68$

Figure 24. Water temperatures for Flaming Gorge Dam (FGD) releases and the Green River at the Jensen gage, air temperature for Vernal, Utah, and mean daily flow at the Jensen gage during the winter of $1992-1993 \ldots \ldots \ldots \ldots 69$

Figure 25. Water temperatures for Flaming Gorge Dam (FGD) releases and the Green River at the Jensen gage, air temperature for Vernal, Utah, and mean daily flow at the Jensen gage during the winter of 1993-1994 . . . . . . . 70

Figure 26. Water temperatures for Flaming Gorge Dam (FGD) releases and the Green River at the Jensen gage, air temperature for Vernal, Utah, and mean daily flow at the Jensen gage during the winter of $1994-1995 \ldots \ldots \ldots \ldots 71$

Figure 27. Water temperatures for Flaming Gorge Dam (FGD) releases and the Green River at the Jensen gage, air temperature for Vernal, Utah, and mean daily flow at the Jensen gage during the winter of $1995-1996 \ldots \ldots \ldots \ldots 72$

Figure 28. Water temperatures for Flaming Gorge Dam (FGD) releases, air temperature for Vernal, Utah, and mean daily flow at the Jensen gage during the winter of $1996-1997 \ldots \ldots \ldots \ldots \ldots \ldots \ldots \ldots \ldots \ldots \ldots \ldots$

Figure 29. Summary of USGS ice observations $\ldots \ldots \ldots \ldots \ldots \ldots \ldots \ldots \ldots$

Figure 30 . Observed extent of ice on 28 January $1987 \ldots \ldots \ldots \ldots \ldots \ldots \ldots$

Figure 31 . Observed extent of ice on 29 January to 20 February $1987 \ldots \ldots \ldots \ldots 76$

Figure 32. Observed extent of ice on 31 January $1988 \ldots \ldots \ldots \ldots \ldots \ldots \ldots 77$ 
Figure 33. Observed extent of ice on 18 to 19 December $1996 \ldots \ldots \ldots \ldots \ldots$

Figure 34. Observed extent of ice on 28 December 1996. . . . . . . . . . . 79

Figure 35 . Observed extent of ice on 25 January $1997 \ldots \ldots \ldots \ldots \ldots \ldots \ldots$

Figure 36. Observed extent of ice on $29-30$ January $1997 . \ldots \ldots \ldots \ldots \ldots$

Figure 37. Ice thickness measurements at cross section locations before and after peaking flows occurred in the study reach $\ldots \ldots \ldots \ldots \ldots 2$

Figure 38. Measured stage hydrographs for seven locations within the study area $\ldots .83$

Figure 39. Ice model results for the winter of $1989-1990 \ldots \ldots \ldots \ldots \ldots \ldots$

Figure 40. Ice model results for the winter of $1990-1991 \ldots \ldots \ldots \ldots \ldots \ldots$

Figure 41. Ice model results for the winter of $1991-1992 \ldots \ldots \ldots \ldots \ldots \ldots$

Figure 42. Ice model results for the winter of $1992-1993 \ldots \ldots \ldots \ldots \ldots \ldots$. . . . . 87

Figure 43. Ice model results for the winter of $1993-1994 \ldots \ldots \ldots \ldots \ldots \ldots$

Figure 44. Ice model results for the winter of $1994-1995 \ldots \ldots \ldots \ldots \ldots$. . . . . . . 89

Figure 45. Ice model results for the winter of $1995-1996 \ldots \ldots \ldots \ldots \ldots \ldots$ 


\section{LIST OF KEY WORDS}

Green River, Flaming Gorge Dam, ice processes, ice distribution, ice formation, ice conditions, ice thickness, ice breakup, frazil ice, meteorological conditions, winter flows, peaking flows, daily fluctuations, ice process model 


\section{EXECUTIVE SUMMARY}

This report provides results and conclusions of a detailed investigation of ice processes in the main channel of the reach of the Green River between the downstream end of Split Mountain (River Mile [RM'] 320) and the Ouray, Utah Bridge (RM 248). The objective of the study was to examine the influence of daily fluctuations in water releases from Flaming Gorge Dam on river ice processes in this reach, which serves as an overwintering area for endangered Colorado pikeminnow and razorback sucker. The objective of the study was met through examination of historical records of winter water and air temperatures, flow measurements, and ice observations; through measurements of differences in ice conditions under steady and fluctuating flow regimes; and through calibration and use of an ice process model to compare hydraulic and ice conditions expected under steady and fluctuating flow regimes.

Examination of historical measurements of water and air temperatures, and historical and current (winter of 1996-1997) ice observations indicated that ice occurred within the Green River study reach during every winter for which reliable observations were available. Historical observations of ice recorded by the USGS during discharge measurements were determined to be unreliable indicators of the duration of ice presence during past winters because of the intermittent nature of the observations.

Measurements of ice thickness were made at 17 cross-section locations within the study reach during the winter of 1996-1997 under steady flows and after several days of fluctuating flows resulting from initiation of a peaking flow regime at Flaming Gorge Dam. Ice cover broke up at the three upstream-most cross section locations in the study reach during the first few days of fluctuating flows. These three sites were located upstream of the Jensen Bridge, at RM 307.0, 308.2, and 316.3. Mean ice thickness at the 14 remaining cross section locations (between Jensen Bridge [RM 300] and Ouray Bridge [RM 248]) was not significantly different under steady flows and fluctuating flows.

A change in flow of approximately $1,800 \mathrm{cfs}$ at the Jensen gage resulted in measured stage (surface elevation) changes at seven sample locations that ranged from $24 \mathrm{~cm}$ at the upstream end of the study reach to $6 \mathrm{~cm}$ at the downstream end of the study reach. The upstream 5 miles of ice cover in the study reach broke up after several days of fluctuating flows.

Formation of ice cover in the study reach appeared to follow a consistent pattern during winters for which historical observations were available and the daily release schedule of Flaming Gorge Dam, whether steady or fluctuating as a result of hydropower demand, was found to have no apparent effect on the basic pattern. The initial type of ice reported for each winter for

\footnotetext{
'Distances reported as RM represent the distance upstream from the confluence of the Green and Colorado Rivers, unless otherwise noted.
} 
which historic observations were available was frazil ice, transported at the water surface in the form of slush, floes, and pancake ice. A stationary ice cover formed initially near the Ouray Bridge and progressed upstream from that point. Ice cover in all years is probably formed primarily by juxtaposition of floes up to about RM 290. Upstream of RM 290, underturning of ice floes and a rougher ice surface were more typical during the 1996-1997 study and is probably similar under most winter conditions. The reported upstream extent of the ice cover was typically at least up to RM 302 and often extended upstream of this point. No complete ice cover was reported upstream of Chew Bridge (RM 316), except for short, isolated stretches during a particularly severe winter. Apparently the river gradient in the study reach is too steep to allow ice progression past this point during most winters.

A numerical model of dynamic ice formation in the Green River was developed using empirical information and used to simulate ice cover formation on the Green River for the winters of 1989-90 through 1995-96. The ice model results were in general agreement with historical ice observations during these years. Analysis of hydraulic conditions that occurred during the winter of 1996-1997, together with the ice process model was used to evaluate the potential effects of daily fluctuations on ice formation and breakup. The results indicated that daily fluctuations of releases similar to those observed during 1996-1997 (approximately 1,800 cfs) from Flaming Gorge Dam would be unlikely to affect ice cover in the main channel of the Green River downstream of RM 300 (Jensen Bridge) under most winter conditions. Upstream of the Jensen Bridge daily fluctuations have a more pronounced effect and are more likely to affect ice cover formation and breakup. During especially cold winters, when production of frazil ice would be high, large daily fluctuations in flow would probably transport frazil ice beneath the ice cover in the reach above the Jensen Bridge. This would result in an ice cover thicker than ice covers that would occur through this reach under steady flow. Frazil depositions several feet thick were observed in this portion of the study reach during the winter of 1987-1988 when water releases from Flaming Gorge Dam fluctuated daily. The ice cover that developed in the upper portion of the study reach under conditions of steady flow during the 1997 field survey was about $24 \mathrm{~cm}$ thick.

Recommendations resulting from this study include:

1. To prevent ice breakup, or the transport and deposition of frazil ice in areas used by overwintering endangered fishes, large daily fluctuations at the Jensen gage should be avoided during extremely cold weather (mean daily air temperature about $-7^{\circ} \mathrm{C}$ or below) until surface ice has formed to approximately RM 310. During milder winters, when frazil ice production is reduced, less restrictive operations could occur without depositing frazil ice under the ice cover and without breaking up all but the thinnest ice covers past about RM 300 (Jensen Bridge).

2. Initiate a program to collect accurate hourly or sub-daily water temperatures during 
winter to allow for more accurate temperature modeling for the Green River and to investigate the effect of release volumes and fluctuating flows on temperature regimes in downstream areas of the Green River.

3. Conduct additional investigations to characterize winter conditions in backwaters and other low-velocity habitats that may serve as overwintering areas for juvenile endangered fishes. 


\section{INTRODUCTION}

The Green River originates in western Wyoming, flows south through Wyoming, Utah, and Colorado and merges with the Colorado River in southeastern Utah (Figure 1). The Green River provides habitat for the Federally endangered Colorado pikeminnow (Ptychocheilus lucius), razorback sucker (Xyrauchen texanus), humpback chub (Gila cypha), and bonytail (Gila elegans). Since October of 1962, flows in the portion of the Green River in Utah and Colorado have been regulated by Flaming Gorge Dam, located near the border of Utah and Wyoming (Figure 1). Construction and operation of the dam has affected the downstream portions of the river by altering the seasonal pattern of flows and water temperatures, increasing daily fluctuations in flow and river stage, and reducing sediment loads. Because of these and other changes, there are concerns pertaining to the effects of the dam on the viability of the populations of endangered fishes in the downstream portions of the river.

While there have been numerous studies conducted to examine the effects that flows from Flaming Gorge Dam have on endangered fish populations and habitats during spring, summer, and fall periods of the year, there have been relatively few investigations conducted during winter months. Fluctuations in flow during winter have been observed to increase the activity of some Green River endangered fishes especially during ice breakup and formation of ice jams (Valdez and Masslich 1989; Valdez 1994). Shoreline scouring that can result from ice breakup and movement may also adversely affect overwintering endangered fish (USFWS 1992), although effects from scouring have not been documented. Although the degree to which fluctuating flows in winter, ice breakup, and shoreline scouring may affect endangered fish is not well understood, it would be prudent to avoid repeatedly or prematurely breaking up ice covers that form on the river in areas used by overwintering endangered fish. In order to more accurately evaluate potential effects on endangered fish, quantitative information about the effects of fluctuating flows due to hydropower or maintenance operations at Flaming Gorge Dam on ice processes in the Green River is needed. A need for additional information about the effects of winter flows on conditions in overwintering areas for endangered fishes was also identified in the Biological Opinion on the Operation of Flaming Gorge Dam (USFWS 1992).

This report presents the results of an investigation of ice processes in the main channel of a section of the Green River extending from Split Mountain Canyon (about 90 miles downstream of Flaming Gorge Dam) to the Ouray, Utah Bridge (about 161 miles downstream of the dam), where overwintering razorback suckers and Colorado pikeminnow adults have been observed in the past (Valdez and Masslich 1989). Specifically, the objective of the study was to examine the influence of daily fluctuations in water releases from Flaming Gorge Dam on the formation, breakup, and movement of river ice in the main channel of this reach of the river. In order to better understand ice processes in the Green River, historical records of winter water temperature, flow, and ice conditions were reviewed and analyzed. In addition, a field study was 
conducted during the winter of 1996-1997 to make observations of the river ice conditions and to measure the response of the ice cover to Flaming Gorge Dam releases that were steady throughout the day and to releases that fluctuated over a 24-hr period. A flow routing model of the study reach of the Green River was developed using available surveyed river cross-section information. This model, calibrated using the 1996-97 survey data, allowed us to predict and evaluate the effects of daily fluctuations in flow on hydraulic conditions in the study area and to estimate the limits of the river influenced by the fluctuating releases. Finally, a model of river ice processes in the Green River study reach was developed and combined with the unsteady flow model to simulate the formation of ice in the Green River during winters for which appropriate data were available: the winters of 1989-1990 through 1995-1996. Impacts of hydropower releases on ice processes in the Green River were evaluated using these models.

\subsection{RIVER ICE FORMATION}

The formation of river ice cover reflects the meteorologic and hydrologic conditions of the region through which the river flows and the hydraulic conditions of the river channel itself. Ice production in a river begins when the river water reaches a temperature of $0^{\circ} \mathrm{C}$. The river water temperature represents the balance of heat transfer into and out of the river. In most rivers, the dominant heat exchange is between the water surface and the atmosphere. The reservoir behind Flaming Gorge Dam represents a large source of stored heat during the winter. Measurements indicate that the temperature of water released from Flaming Gorge Dam rarely falls below about $4^{\circ} \mathrm{C}$ in the winter (although Valdez and Masslich [1989] reported that the temperature of releases varied from $1.7^{\circ} \mathrm{C}$ to $6.2^{\circ} \mathrm{C}$ during $1987-1988$ ). Downstream of Flaming Gorge Dam, any heat input into the river, other than through the water surface, is probably minor. During cold weather, the Green River cools in response to heat loss from the water surface to the atmosphere. The distance downstream of Flaming Gorge Dam where water temperature drops to $0^{\circ} \mathrm{C}$ depends on the release temperature, the heat transfer rate, and the volume of water being released. The point at which substantial ice formation first occurs in the main channel identifies the approximate downstream extent of the winter temperature influence of releases from Flaming Gorge Dam. Records indicate that the winter water temperature in the Green River is often $0^{\circ} \mathrm{C}$ by the time it reaches the upstream end of the study reach (Section 2.1).

The type of ice formed in the Green River is controlled by the flow conditions in the channel. In the faster moving reaches, frazil ice will form. Frazil ice is ice particles formed in turbulent, supercooled water (i.e., temperatures slightly below the freezing point). Frazil ice does

\footnotetext{
${ }^{1}$ Based upon historic meteorological conditions and reports of ice occurrence, the winter period in this report is considered to extend from November through March. Thus, the winter of 1996-1997 refers to November 1996 through March 1997.
} 
not form in an area once a solid ice cover has been established because the ice cover insulates the underlying water from sub-zero air temperatures and prevents supercooling. Soon after they are formed, frazil ice crystals are a few tenths of a millimeter in diameter. Typically, frazil ice crystals will be approximately uniformly distributed throughout the depth of the flow, especially in highly turbulent, shallow reaches. The many rapids located in the high-gradient reach through Split Mountain Canyon, just upstream of the study area, are particularly favorable for frazil ice production during cold weather. Following formation, frazil ice is transported downstream by the river current and evolves in form as it is transported (for a more complete description of this process, see Daly 1994). Individual frazil crystals gather into larger and larger masses of ice known as flocs. In areas with higher water velocities and turbulent flows, frazil ice can remain mixed throughout much of the water column. Under less turbulent conditions, frazil flocs rise to the water surface. Frazil slush is the collection of frazil flocs and individual frazil crystals on the water's surface in a distinct layer. Frazil slush at the water surface has a marked tendency to clump together. The initial clumps, if they remain at the surface long enough, can further clump together and form pans, or small floes. These pans often grind against one another, causing them to become roughly circular in shape and gain upturned edges. At this point they are known as pancake ice (photographs and additional descriptions of pancake ice in rivers can be seen in Ashton [1986] and Beltaos [1995]). Frazil slush and floes can accumulate along or abrade the edge of border ice, which forms along the banks of the river channel. It is common to see parallel lines of raised frazil slush along the inside edge of border ice, marking periods when frazil ice accumulated along the border ice.

In slower moving areas of the river, such as regions behind islands or in the lee of sandbars, where there is very little or no mixing due to the locally reduced velocity, the surface of the water can cool sufficiently for ice crystals to form directly on the water surface. Ice that forms directly on the water surface in areas with little or no flow velocity is said to result from static ice formation. This type of ice is also formed on lakes and ponds during periods of low winds. Generally the surface flow velocity must be approximately 1 foot per second or less for static ice to form. Static ice formation starts in a very thin layer of supercooled water at the water surface, and is probably initiated by the introduction of seed ice crystals from the air. Ice thickens as a result of continued ice formation at the ice/water interface as heat is transferred from the ice/water interface through the ice and into the atmosphere.

The formation of a stable riverine ice cover results from the interaction between the transported ice pieces and the flowing water. In this case the cover is said to form dynamically. Ice covers that form dynamically progress in an upstream direction from an initiation point as ice is transported to and deposited at the leading edge (upstream edge) of the ice cover by the flow of the river. The actual process that occurs at the leading edge depends on the hydraulic flow conditions and the form of the arriving ice. The processes at the leading edge are described in general below in an order which reflects the relative flow velocity at which they occur, from the lowest flow velocity to the highest. However, it is more common to refer to the non-dimensional 
flow velocity, or Froude number, defined as

$$
\frac{V}{\sqrt{g D}},
$$

where $V=$ the flow velocity, $g=$ acceleration due to gravity, and $D=$ mean depth. The magnitude of the Froude number is an indication of the magnitude of hydraulic forces that affect ice formation and breakup at a given location.

At relatively low flow velocities and high concentrations of surface ice (approximately $50 \%$ coverage or higher) it is possible for the ice cover to spontaneously arch across the width of the open area of the channel and stop moving as gaps between ice floes freeze, a process known as bridging. It is generally not possible to predict where these bridging locations will be in a particular river without historical knowledge. Ice control booms and/or hydraulic control structures are often used to assure the initiation of ice cover at a specific location. At relatively low flow velocities, ice floes that continue to arrive at the leading edge of the bridging location may come to a stop adjacent to the leading edge. In such cases, the ice cover will progress upstream by juxtaposition. The maximum flow velocity at which juxtaposition will occur depends on floe geometry and channel depth. At higher flow velocities, the ice floes arriving at the leading edge of ice cover may be forced underneath the existing ice cover or underturn. If the flow velocity is not too high, these underturned floes will remain at or near the leading edge of the ice cover. In some cases, accumulations of underturned floes and frazil slush can become packed under a stationary ice cover, especially in areas where flow velocity is lower.

The strength of an ice cover formed from many separate pieces of ice is directly proportional to its thickness. If the forces acting on the ice cover exceed the ability of the cover to withstand those forces, the ice cover will sometimes collapse in the longitudinal direction and become thicker, a process known as shoving. When shoving occurs, the strength of the ice cover is increased. An ice cover may repeatedly shove and thicken as formation progresses in the upstream direction. If the ice cover is treated as a "granular" material, the strength characteristics and the final thickness of the cover can be mathematically estimated.

At relatively high flow velocities, the ice floes arriving at the leading edge of the ice cover may be underturned and transported under the ice cover for considerable distances. At this point, further upstream progression of the ice cover may be halted until the deposition of the floes somewhere downstream of the leading edge reduces channel conveyance enough to cause upstream water levels to rise and the flow velocities at the leading edge to be reduced. If flow velocities are high enough, the ice cover will stop progressing upstream. In this case, open water will remain upstream of the leading edge throughout the winter season.

Intact stationary ice covers break up in the spring. Two ideal forms of breakup bracket the types of breakup commonly found throughout most of North America. At one extreme is 
thermal meltout. During thermal meltout, the ice cover deteriorates through warming and the absorption of solar radiation and melts in place, with no increase in flow and little or no ice movement. At the other extreme is the more complex and less understood mechanical breakup. Mechanical breakup requires no thermal deterioration of the ice cover but rather results from an increase in flow entering the river (e.g., runoff from melting snow). The increase in flow induces stresses in the cover, and the stresses in turn cause cracks and the ultimate fragmentation of the ice cover into pieces that are transported by the channel flow. Ice jams occur at locations where the ice fragments stop; severe and sudden flooding can result when these ice jams form or when they release. Most river ice breakups actually fall somewhere in between the extremes of thermal meltout and mechanical breakup because breakup usually occurs during warming periods when the ice cover strength deteriorates to some degree and the flow entering the river increases due to snow melt or precipitation. As a general rule, the closer that a breakup is to being a mechanical breakup, the more dramatic and dangerous it is because of the sudden increase in flow and the large volume of fragmented ice produced. 


\section{METHODS}

\subsection{THE STUDY REACH}

The study reach of the Green River extended from the downstream end of Split Mountain Canyon (about River Mile $\left[R M^{1}\right] 320$ ) to the Ouray Bridge (RM 248) (Figure 2). Flaming Gorge Dam is located about 90 river miles upstream of the study reach at RM 410. As presented in Valdez and Masslich (1989), the study reach can be effectively subdivided into two segments, based upon channel characteristics. The segment from Split Mountain Canyon to the Jensen Bridge (RM 302) comprises the upstream segment of the study reach. This segment has a moderate gradient with a substrate consisting primarily of gravel and cobble in the upstream portion and sand in the downstream portion. The downstream segment of the study reach extends from the Jensen Bridge to the Ouray Bridge and is generally a low-gradient, meandering river with a substrate primarily composed of sand. Upstream of the study reach, where the Green River passes through Split Mountain Canyon, the river has a high gradient, numerous rapids, and a substrate of mostly cobble and boulders.

\subsection{HISTORICAL CONDITIONS AND OBSERVATIONS}

Information pertaining to conditions in the Green River during the winter was obtained from historical records in order to assess whether these data provided evidence that daily fluctuations had affected the historical formation or distribution of ice in the study area. These records were also used to evaluate data collected during the 1996-1997 field study and for use in modeling ice processes in the Green River. The data collected included historical information about winter flows, water temperature, air temperature, and observations of ice formation and distribution in the Green River.

\subsubsection{Flow Rates}

Information about releases from Flaming Gorge Dam was primarily based upon records for the gage located near Greendale, Utah (U.S. Geological Survey [USGS] Station No. 09234500) and power generation records for the dam. The period of record for the Greendale gage, which is located 0.5 river miles downstream of the dam at RM 409.5, is October 1950 to the present. Flow at this gage has been regulated by Flaming Gorge Dam since November 1, 1962.

${ }^{1}$ Distances reported as RM represent the distance upstream from the confluence of the Green and Colorado Rivers, unless otherwise noted. 
The evaluation of flow in the study reach during the winter was based upon records from the Jensen gage (USGS Station No. 09261000), located approximately 93 river miles downstream of the dam at RM 316.6, in the upstream end of the study reach. There is a nearly continuous record for this gaging station for the period from October 1946 to the present.

\subsubsection{Water and Air Temperature Measurements}

Periodic water temperature measurements of the Green River have been made by the USGS at their Jensen gage site. Measurements of the temperature of water released from Flaming Gorge Dam were also available for some years. Maximum and minimum daily air temperature measurements were obtained from three weather recording stations in the vicinity of the study reach: 1) Dinosaur Quarry in Dinosaur National Monument, 2) Vernal, Utah, and 3) the Ouray National Wildlife Refuge. The air temperature measurements from these sites were similar, differing by only about $0.6^{\circ} \mathrm{C}$ on any given day. For the purposes of this study, it was decided to use the Vernal, Utah air temperature records, which were more extensive and complete than for the other recording stations. The daily average air temperature was estimated for each day by taking the average of the maximum and minimum temperature reported for each day (Panofsky and Brier 1968).

A good index of the severity of a winter can be calculated by totaling the number of freezing degree days ("accumulated freezing degree days", abbreviated AFDD) throughout the winter period. The number of freezing degree days that occur on any day is found by subtracting the daily average air temperature from $0^{\circ} \mathrm{C}$. For example, if the daily average temperature is $-5{ }^{\circ} \mathrm{C}$, the number of freezing degree days for that day would be 5 . If the daily average temperature is above $0{ }^{\circ} \mathrm{C}$, a negative number of freezing degree days is found for that day. The severity and length of winters in the study area were determined for each year from 1950 through 1997 by finding maximum AFDD for each winter period and by determining the date on which the maximum AFDD value occurred.

\subsubsection{Historical Ice Observations}

There are only a limited number of historical ice observations available for the Green River in the vicinity of the study area. These include a summary of USGS observations made at irregular times throughout the winter ${ }^{2}$, and the BIO/WEST reports of Valdez and Masslich (1989) and Valdez and Cowdell (1999).

\footnotetext{
${ }^{2}$ The summary of USGS observations was based upon information in unpublished USGS logbooks obtained in 1992 by Dr. Jack Schmidt, University of Utah.
} 
In addition, several surveys of ice cover distribution in the study reach of the Green River were conducted during this study. The first survey was conducted on 18-19 December 1997 before consolidated ice cover was present in most of the study reach. The second survey was conducted on 23-25 January 1997, after a consolidated stationary ice cover had formed on the river and just prior to the arrival of fluctuating flows in the study reach. The third survey was conducted on 28-29 January 1997, after several days of fluctuating flows within the study reach. These surveys were conducted by field teams that drove to multiple locations along the river and documented the presence or absence of ice cover and noted various characteristics of the ice cover (e.g., stationary vs. moving ice cover; frazil pans vs. consolidated ice cover; locations of ice jams) for the entire river reach. Brief inspections of the extent of ice cover were also conducted from small airplanes on 28 January and 20 February 1997.

A summary of the ice observations from each of these sources is presented in Section 3.1.3.

\subsection{6-1997 FIELD MEASUREMENTS}

Releases from Flaming Gorge Dam were manipulated during the winter of 1996-1997 to allow comparison of ice conditions in the study reach under steady flows with conditions after peaking flows. After ambient air temperatures, water temperatures, and weather conditions became conducive to formation of ice cover (water temperatures near $0{ }^{\circ} \mathrm{C}$ and a weather forecast of consistent sub-zero air temperatures), releases from Flaming Gorge Dam were held steady for a 3-week period while ice cover formed within the study reach. This steady flow period, which began on 29 December 1996, was followed by a period of fluctuating flows; both periods had a mean release of 1,900 cfs from Flaming Gorge Dam. A field team observed and measured ice conditions on the Green River before, during, and after the peaking period. Goals of the field investigation were to document ice conditions before and after the wave from the peaking cycle passed through the study reach, and to record water and ice stage changes at cross-section locations as a hydropower-induced wave passed through the study reach. In addition to providing on-the-ground observations, this information was also needed to complete and calibrate modeling of ice processes in the Green River.

During 25-28 January 1997, two teams worked alternating 8-hour shifts, to measure the relative water and ice stage at seven cross-sections (Figure 3) at approximately 1 hour intervals from just prior to the passage of the first peak release until changes in the measured stage indicated the first trough of the release had passed through each cross-section location. At the Chew (RM 316), Jensen, Bonanza (RM 290), and Ouray Bridges, the distances from the ice or water surface under the bridge to fixed reference points on the bridge rails were measured. At the remaining three sites (RM 254.5, 279.0, and 307.0; see Figure 3), changes in stage of the ice cover were measured by using shoreline-based surveying instruments to observe vertical 
movements of stadia rods that had been attached to wooden stands placed on the ice.

In addition to measurements of ice distribution and stage changes, field teams spent 23-25 January 1997 measuring ice thickness and channel depth at multiple locations across the river channel at 17 river cross sections under the steady flow regime. These measurements were made by using a hand-operated ice auger to create $5.7 \mathrm{~cm}$ holes in the ice cover and a tape measure with a hinged weight to obtain the measurement of ice thickness at each hole following the procedures of White and Zufelt (1994). The water depth at each sample hole was measured with a graduated stadia rod inserted through the hole in the ice. Measurements of ice thickness and channel depth were repeated at the same cross-sections (but using slightly different locations for the holes) on 29-30 January, after the propagation waves from several hydropower peaking cycles had passed through the study area. The locations of the ice measurement cross sections are shown in Figure 3. Because the measurements made at each cross section were considered to be repeated measurements made before and after a treatment (fluctuating flows), mean ice thickness under steady and peaking flows were statistically compared using a repeated measures ANOVA (SAS 1985). In this statistical design, the Type III mean square of the ice thickness measurements within cross sections was used as the error term when testing the hypothesis that the flow regime (i.e., steady releases vs fluctuating releases) affected the thickness of the ice.

In the event that stage fluctuations resulting from hydropower peaking caused breakup or downstream movement of the ice cover, ice motion detectors were installed at three locations within the study reach. Each detector consisted of a sensor unit and a wire circuit. Each sensor unit, which contained an internal clock to record the date and time, was installed on the shoreline and the wire connected to the unit was embedded in the ice cover through holes drilled in the ice. The detectors were designed so that any break in the wire, such as would occur if the ice cover moved, would cause the sensor to record the date and time when the circuit was broken. The first ice motion detector was placed at RM 308.2 on 25 January 1997. A second ice motion detector was installed upstream of the Bonanza Bridge at RM 290.4 on 26 January, and a third was installed within the Ouray National Wildlife Refuge at RM 254.3 on 30 January 1997.

\subsection{ICE PROCESS MODELING}

The formation and transport of river ice and the formation of stationary river ice covers can be simulated through the use of numerical models (see for example Lal and Shen 1993; Shen et. al. 1991; Beltaos 1995) and such a numerical ice model (Daly, in prep.) was applied to the study reach of the Green River. This model is composed of a one-dimensional unsteady flow sub-model, a transport sub-model, and an ice cover progression sub-model. Each of the sub-model components are described in the following subsections.

In order to understand the influence that the Flaming Gorge Dam release pattern could 
have on Green River ice processes, the model was used to examine hydraulic conditions throughout the study reach for two alternate release schedules. In the first schedule, the releases were held constant for a number of days. In the second schedule, the releases were varied each day in a manner consistent with a typical peaking pattern used to follow the demand for hydropower. The complete ice model was applied to the Green River study reach using the meteorological and hydrological conditions that occurred during the winters of 1989-1990 through 1995-1996. These are the winters for which both water temperature and discharge data were available at the Jensen Gage. The daily average discharge, air temperature, and water temperature were used as inputs to the model.

\subsubsection{Unsteady Flow Sub-Model}

The basis for the Green River unsteady flow sub-model was the UNET one-dimensional unsteady flow model (U. S. Army 1995), calibrated to steady flow data from the Green River Flooded Bottomlands Investigation (FLO Engineering, Inc. 1996) and the observed stage hydrographs collected during the January 25-29, 1997 peaking period. The UNET model simulates unsteady flow in a river channel through solution of one-dimensional continuity and momentum equations. The equations are solved using the four-point, implicit, finite difference scheme. Surveyed and estimated river cross sections, as described below, were used as input to the model to represent the river channel in the study reach. The model time step can be adjusted by the user; a 30-minute time step was used for the results presented in this report. The UNET model can also simulate a floating, stationary ice cover with known thickness and roughness. The composite roughness of the river channel was determined by combining the roughness of the channel bed and the ice cover using the method of Sabaneev (Ashton 1986). The model also accounted for the cross-sectional area of the flow blocked by the ice and the reduction in the hydraulic radius caused by the increase in wetted perimeter due to the ice cover. A number of different boundary conditions can be set by the user for the upstream and downstream limits of the channel. In the present case, a known time-varying discharge was proscribed at the upstream end of the channel and normal depth was set at the downstream end.

The upstream boundary of the model used the observed discharge hydrograph at the USGS Jensen gage for 25-30 January 1997. Because no surveyed channel cross-section data were available for the upstream end of the study reach, the channel geometry at RM 316.6 was estimated to reproduce the stage-discharge curve for the Jensen gage (Figure 4). The model used a Manning equation to calculate the normal depth at the downstream-most cross section (located 2 miles downstream from the Ouray Bridge at RM 246). A bed slope of 0.0002 and a Manning's $n$ of 0.035 produced the stage-discharge relationship shown in Figure 5 for the Ouray Bridge location (RM 248). The observed stage of $4654.4 \mathrm{ft}$ MSL at a discharge of $15,500 \mathrm{cfs}$ was from the Green River Flooded Bottomlands Investigation (FLO Engineering, Inc. 1996; see below). 
The unsteady flow sub-model used continuity and momentum equations to describe river flow in finite difference form. The model solved these equations for each river cross section through multiple time steps. The model used surveyed or estimated Green River geometry to calculate discharge and stage at multiple cross sections of the river as a function of time, using the observed upstream discharge as input. The model was calibrated to match the water surface response to each alternate release schedule observed during the field survey.

The UNET model was also modified to incorporate the dynamic formation of river ice covers as determined by the ice cover progression sub-model. The ice cover progression sub-model (Section 2.4.3) predicts the sections of the channel in which a stationary floating ice cover will form. The presence of a stationary ice cover in a section changes the hydraulic properties of that section. These changes include reducing the cross-sectional area of the channel available for flow, reducing the hydraulic radius of the channel cross section, and modifying the effective channel roughness. These changes in the hydraulic properties in turn influence the discharge and stage calculated by the unsteady flow sub-model.

\subsubsection{Channel Geometry Data}

FLO Engineering, Inc. provided 37 surveyed cross sections for the Green River in the vicinity of the Ouray National Wildlife Refuge, between RM 248 and 265. These data were in the format of the HEC-2 water-surface profile model (U. S. Army 1990) and were calibrated to observed water levels at a measured flow of 15,500 cfs (FLO Engineering, Inc. 1996). Additional surveyed cross-section data were obtained from the Bureau of Land Management (BLM). These cross sections were also surveyed by FLO Engineering, Inc. in conjunction with the Recovery Program's Channel Monitoring Program, and were located in areas between RM 269 and 290 and in the vicinity of the Escalante Wetlands and Razorback Island (RM 305-312). The cross-sectional geometry for the remainder of the study reach was estimated from USGS 1:24,000 scale, 10-ft contour interval topographic maps and from depth measurements made during the 25-30 January 1997 field study.

\subsubsection{Calibration of UNET Unsteady Flow Model}

Calibration options for the UNET model include adjustments of the channel bed roughness, the roughness of the ice cover and the ice cover thickness. In addition, the hydrographs of water stage simulated by the UNET model can be calibrated by making minor changes in the conveyance and storage capacity of selected reaches of river. Conveyance $(K)$ is defined as:

$$
K=\frac{1.49}{n} A R^{\frac{2}{3}},
$$


where $n=$ Manning's roughness coefficient; $A=$ flow area; and $R=$ hydraulic radius. Increasing conveyance in a reach decreases stage while decreasing conveyance has the opposite effect. Increasing the storage capacity of a reach delays the arrival of a flood wave at a downstream location, while decreasing storage reduces the wave's travel time through a reach.

For the 37 surveyed cross sections in the vicinity of the Ouray National Wildlife Refuge, bed roughnesses from the Green River Flooded Bottomlands Investigation (FLO Engineering, Inc. 1996) were used. For the remaining upstream reaches, an estimated roughness of 0.035 was used to represent a gravel-bedded river with minor surface irregularity and gradual variation in cross sectional geometry (Chow 1964).

Ice cover thickness, roughness, and spatial extent for the steady flow period were selected to represent the pre-peaking conditions observed during 23-24 January 1997. An ice cover with a thickness of $21 \mathrm{~cm}$ and a roughness of 0.025 was applied to the reach from the Ouray Bridge to the Jensen Bridge in order to represent a cover composed of thermally grown sheet ice and juxtaposed frazil pans. From the Jensen Bridge up to the leading edge of the ice cover near Razorback Island, an ice thickness of $24 \mathrm{~cm}$ with a roughness of 0.03 was used, representing an ice cover composed mainly of juxtaposed and slightly shoved frazil pans and floes. Table 1 summarizes the calibration parameters used in the UNET model; cross-section location and type are shown graphically in Figure 6, along with ice cover extent.

The UNET model was calibrated to observed stage hydrographs at the seven locations indicated in Figure 6. Simulated and observed stage hydrographs for these seven locations are presented in Figures 7 through 13. Calibration results were generally quite good with a few exceptions. The measured stage hydrograph at the Chew Bridge location (RM 316.3) is more peaked than the reported stage hydrograph for the nearby Jensen gage (RM 316.6) (Figure 7), possibly because the channel is more narrow at the bridge than at the gage location a short distance upstream. Similarly, the observed hydrograph at the Jensen Bridge location (RM 302.3) is more peaked than the simulated result (Figure 9). The simulated and observed hydrographs agree quite well in terms of total wave height and timing of the peak at Dinosaur Bend (RM 307.1; Figure 8), Bonanza Bridge (RM 294.0; Figure 10), and Horseshoe Bend (RM 279.4; Figure 11). At the Ouray National Wildlife Refuge (RM 254.6; Figure 12) and the Ouray Bridge (RM 248.0; Figure 13), the timing of the first hydrograph peak and the total wave height are simulated fairly well. The simulated falling limbs of these hydrographs are less steep than the observed falling limbs, however. Resolution may be a problem in this part of the river because observed wave height is small, on the order of 0.3-0.4 ft. Also, these downstream sites are more than 60 miles from the location of the observed inflow hydrograph at the Jensen gage (RM 316.6), the upstream boundary of the model. 


\subsubsection{Transport Sub-Model}

The transport sub-model calculated the advection of water temperature, surface ice, and suspended frazil ice. Frazil ice production was assumed to begin through the introduction of seed crystals at the water surface. The concentration of the frazil ice was calculated by balancing the heat loss from the water surface and latent heat released from the growing frazil. The frazil ice was assumed to rise to the water surface with a known velocity. At the water surface, the frazil ice formed into floes that were transported downstream at a rate determined by the flow velocity. The heat loss from the water surface was calculated as a linear function of the difference between the water temperature and the air temperature. The transport sub-model used the Preissman-Holly advection scheme (Cunge et al. 1980). This scheme has been shown to minimize numerical diffusion.

\subsubsection{Ice Cover Progression Sub-Model}

The ice cover progression sub-model calculated the rate at which stationary ice covers formed. A stationary ice cover was assumed to initially form at a pre-selected bridging location when the concentration of surface ice reached a pre-selected value. The ice cover then progressed upstream at a rate determined by the rate of arrival of the surface ice and the thickness of the ice cover. The ice cover was allowed to thicken through heat transfer to the atmosphere from the ice surface and through the deposition of frazil ice underneath the ice cover. The ice cover could also melt out through heat transfer from the water flowing beneath it. When the ice cover lost a certain percentage of its thickness, it was assumed to break up and be transported in the downstream direction.

The river cross sections and channel bed and ice cover roughnesses developed for the unsteady flow model were used to describe the channel geometry in the transport model. The initial ice cover bridging location was set at the Ouray Bridge and bridging was assumed to begin when a surface ice concentration of $50 \%$ was reached. The initial stationary ice cover thickness for the bridging location was based on the observations of ice cover thickness during the 1997 field measurements. The frazil ice rise velocity was set at $0.03 \mathrm{~cm} / \mathrm{sec}$, initial floe thickness was set at $3 \mathrm{~cm}$, and the model used a time step interval of 2 hours. The channel and ice cover roughnesses used in the UNET simulation described in section 2.4.1 were used in the ice progression simulation. 


\section{RESULTS}

\subsection{HISTORICAL CONDITIONS AND OBSERVATIONS}

\subsubsection{Winter Flows}

Releases from the dam are determined by a number of factors, including basin hydrology, reservoir storage, maintenance of a downstream trout fishery, endangered fish needs, and generation of hydropower. Compared to pre-dam historical records, Flaming Gorge Dam has reduced the magnitude of peak spring flows and has increased the magnitude of flows in the fall and winter. This alteration in the seasonal distribution of flows is clearly depicted in Figure 14, which shows the mean daily discharge at the Greendale, Utah gaging station for each day of the year for the period 1950-1962 (pre-dam period of record) compared to the mean daily discharge for each day of the year for the period 1963-1997 (post-dam). The Green River is joined by its largest unregulated tributary, the Yampa River, 65 miles downstream of Flaming Gorge Dam (Figure 1). As a result, the difference between pre-dam and post-dam flows downstream of the confluence is less pronounced than for flows upstream of the confluence, although changes to the seasonal pattern and magnitude of flow levels are still evident (Figure 15).

Mean daily winter flows (defined here as November through March) at the Jensen gage ranged from $314 \mathrm{cfs}$ to $24,200 \mathrm{cfs}$ (mean $=1,507 \mathrm{cfs}$; $\mathrm{SD}=1,522 \mathrm{cfs}$ ) during the 16 years prior to construction of Flaming Gorge Dam (Figure 16). Following construction of Flaming Gorge Dam (January 1963 through March 1997), mean daily flows ranged from $415 \mathrm{cfs}$ to $9,710 \mathrm{cfs}$ (mean $=2,785 \mathrm{cfs} ; \mathrm{SD}=1,214 \mathrm{cfs}$ ) (Figure 17). During both pre-dam and post-dam periods of record, flows tend to increase near the end of February reflecting the early beginnings of the spring runoff. The flow continues to increase through the month of March and typically reaches a peak in late May or early June.

Use of Flaming Gorge Dam as a peaking hydropower facility has also led to increased daily fluctuations in flow at downstream locations during many seasons of the year. Within a 24-hr period, hydropower releases from Flaming Gorge Dam can range from a minimum flow of $800 \mathrm{cfs}$ to a maximum flow of $4,600 \mathrm{cfs}$. Variation in channel morphology along the river and tributary input serve to dampen fluctuations that result from hydropower operations at the dam. The degree of attenuation of operations-induced fluctuations is dependent on specific release parameters including the ramp rate (time between minimum and maximum flow), the minimum and maximum flow levels, and the duration of peak releases. This attenuation or dampening becomes greater at increasing distances from the dam until fluctuations are in the range of natural flow variance at some distance. Under maximum daily peaking powerplant operations ( $800 \mathrm{cfs}$ minimum, 4,600 cfs maximum, and 12 hours of peak releases during a 24-hr period), the 
resulting changes in stage would be approximately $1.5 \mathrm{~m}$ at the Greendale, Utah gage (located $0.8 \mathrm{~km}$ downstream of Flaming Gorge Dam), approximately $1.3 \mathrm{~m}$ at the Gates of Lodore ( $77 \mathrm{~km}$ downstream) and approximately $0.6 \mathrm{~m}$ at the Jensen, Utah gage ( $150 \mathrm{~km}$ downstream) (Yin et al. 1995). Because this release pattern represents the extreme of powerplant operations, daily water stage fluctuations from other operational patterns would be less pronounced. Low flow releases from the dam typically occur at night. Flows usually increase rapidly between 0600 and 0800 hours to the maximum flow rate and then remain approximately constant throughout the day. The flow rate usually decreases between 1800 and 2200 hours back to the minimum flow. The actual release pattern reflects power demand which may vary on any given day.

Hourly releases from Flaming Gorge Dam and the resulting flows recorded at the Jensen gage during the 1997 portion of the field study are presented in Figure 18. During the three weeks before the peaking period, Flaming Gorge Dam maintained a constant outflow of 1,900 $\mathrm{cfs}$, resulting in a relatively steady discharge of approximately $2,440 \mathrm{cfs}$ at the Jensen Gage. Diurnally peaking releases from Flaming Gorge Dam were initiated at 0700 hours on 25 January 1997 , with a range of 800 to $3,000 \mathrm{cfs}$ and a mean outflow of 1,900 cfs. Approximately 1.5 days later, fluctuations related to this peaking cycle were detected at the Jensen gage and resulted in flows that ranged from 1,700 cfs to 3,500 cfs during 26-31 January 1997 (Figure 18).

\subsubsection{Water and Air Temperatures}

The mean daily air temperature for Vernal, Utah from $1945-1997$ was below $0^{\circ} \mathrm{C}$ by about the middle of November and remained below $0{ }^{\circ} \mathrm{C}$ through the winter and until early March (Figure 19). From mid-December until early February, the mean daily air temperature generally remained below $-6^{\circ} \mathrm{C}$. The maximum number of freezing degree days for a number of winters are listed in Table 2 and shown in Figure 20.

The mean daily air temperature at Vernal, the temperature of the water released from Flaming Gorge Dam, and the water temperature recorded at the Jensen gage are shown in Figures 21 through 28 for the winters of 1989 to 1997 (USGS discontinued collection of water temperature data at the Jensen gage prior to the winter of 1996-1997). Also shown in these figures is the daily average discharge of the Green River at the Jensen gage for the same period. It can be seen that the water temperature at Jensen was influenced both by the Flaming Gorge release water temperature and the air temperature. The Green River water temperature at Jensen reached $0{ }^{\circ} \mathrm{C}$ for at least a brief period during each of these winter periods and remained at $0{ }^{\circ} \mathrm{C}$ for considerable periods of time for several winters. During the periods when the water temperature was at or near $0^{\circ} \mathrm{C}$, the daily average air temperature was continuously below $0{ }^{\circ} \mathrm{C}$, often reaching minimums of $-12^{\circ} \mathrm{C}$ or less. It is during periods of very cold air temperatures and with the water temperature entering the study reach at or near $0^{\circ} \mathrm{C}$ that maximum ice production in the study reach would be expected to occur. 


\subsubsection{Ice Formation on the Green River}

\subsubsection{USGS Observations}

The USGS ice observations were made in conjunction with retrieval of discharge measurements from the Jensen gage. The observations are summarized in Figure 29 (personal communication, Bryan Cowdell; based upon unpublished data obtained by Dr. Jack Schmidt, Utah State University, 1992) for the years 1946 through 1992. Shown are the first and last dates ice was reported for the years of record at the Jensen gage. The most striking feature of these data is the apparent decline of observed ice in the years following the closure of Flaming Gorge Dam in November 1962. The creation of the reservoir upstream of Flaming Gorge undoubtedly altered the temperature regime of the river between the dam and Jensen. One of the results of this alteration was to increase winter water temperatures and reduce ice production downstream of Flaming Gorge for some distance. Unfortunately, it is very difficult to use these data to draw any quantitative conclusions about the formation of ice in the study reach because the data were collected irregularly. For example, in 11 of the 30 years following 1962, only one visit to the gage was made during the winter (These years are marked with a question mark in Figure 29.). Dates of observations reflect the USGS schedule of discharge measurement retrieval as much as, if not more than, the actual appearance of ice in the Green River at Jensen. For example, there was no ice observed in the winters of 1986-1987 and 1987-1988 even though the reports of Valdez and Masslich (1989), discussed below, documented extensive ice formation in the Green River for both these years. Therefore these USGS observations cannot be considered reliable indicators of the presence of ice in the Green River at the Jensen gage.

\subsubsection{BIO/WEST Reports}

Ice observations for the Green River are discussed in two reports (Valdez and Masslich 1989; Valdez and Cowdell 1999) on the winter habitat of native fish species in the Green River. These observations occurred during the winters of 1986-1987, 1987-1988 (Valdez and Masslich 1989), 1993-1994, and 1994-1995 (Valdez and Cowdell 1999). The first ice observed during these studies was frazil ice, seen at the water surface in the form of slush and floes. In the winter of 1986-1987, a relatively mild winter (see Figure 20), frazil ice was only seen to form downstream of Jensen Bridge (RM 302). In the winter of 1987-88, a much colder winter, frazil was first observed in Lodore Canyon, about 50 miles downstream of Flaming Gorge Dam. In both winters, frazil was heaviest early in the morning, although for the winter of 1987-1988 Valdez and Masslich (1989) observed that "during extended periods of subzero temperatures ... frazil ice was present in the channel throughout the day." During the winters of 1993-1994 and 1994-1995, observations of frazil were similar (Valdez and Cowdell 1999). In February of 1994, frazil ice was reported to be mixed in the water column upstream of the study area. Within the study area, frazil was seen in the form of "large floating mats" which were termed "lily-pad ice" (undoubtedly pancake ice). 
Stationary ice covers were observed in the Green River immediately following the appearance of frazil ice. The bridging location of the stationary ice cover was not reported, but the downstream limit of the stationary ice was consistently reported as the Ouray Bridge or further downstream. The upstream extent and periods of time the stationary ice cover was in place varied from year to year. In 1986-1987 the maximum upstream extent of the stationary ice was the Jensen Bridge (RM 302), observed on 28 January 1987 (Figure 30). The next day the ice cover retreated downstream. The ice cover was observed to stay in place from RM 270 downstream past Ouray Bridge (RM 250) for the next three weeks (Figure 31). The following year stationary ice was in place from early January through late February of 1988 and the upstream extent of the ice reached Chew Bridge (RM 316) (Figure 32). Short, disconnected areas of stationary ice were also seen upstream of the study area in Rainbow Park and Echo Park. The leading edge of the ice cover retreated to Jensen Bridge (RM 302) on 19 February, and to RM 294 by 27 February. In the winter of 1993-1994, the stationary ice reached Jensen Bridge (RM 302) on 2 February 1994 and extended upstream of the Jensen Bridge for an unreported distance. The stationary ice extent was not reported for the winter of 1994-1995, although it was reported that an "ice jam" occurred below Chew Bridge in the middle of December.

The appearance of the ice cover was described as "smooth" downstream of Bonanza Bridge (RM 290) and having a "highly fractured and irregular surface" upstream of Bonanza Bridge (probably referring to ice formed as a result of static ice formation and juxtaposition of frazil pans, respectively). In February 1988 the ice cover thickness was measured to be $30-50 \mathrm{~cm}$ downstream of Bonanza Bridge with $30 \mathrm{~cm}$ of snow cover. In the winter of 1987-1988, frazil ice was observed to be deposited under the ice cover within an 11-mile reach, from RM 305 to RM 316. The layer of frazil ice deposited beneath the cover was measured as 60 to $90 \mathrm{~cm}$ thick in parts of the main channel. After the ice cover had retreated from this reach, accumulations of frazil ice were observed along the river banks that were 0.3 to $3 \mathrm{~m}$ thick beneath solid ice. At RM $310.3,45 \mathrm{~cm}$ of solid ice was measured.

\subsubsection{Winter of 1996-97 Field Survey}

Surveys of the ice cover conditions on the Green River were conducted during the winter of 1996-1997 as part of the field work for this study. The observations of the first survey, conducted on 18-19 December, indicated that a stationary ice cover was present from the Ouray Bridge to approximately RM 266 and that moving frazil pans were present upstream of that point (Table 3; Figure 33). Additional observations made on 28 December 1996 showed that the leading edge of the ice cover had progressed approximately 10 river miles further upstream (Figure 34; personal observation made by Bryan Cowdell, BIO/WEST, Inc.).

The next survey of ice conditions was conducted from 23-25 January 1997, just prior to initiation of fluctuating flows from Flaming Gorge Dam. During this period, a complete ice cover existed on the Green River from the Ouray Bridge (RM 248.2) to a location just 
downstream of Razorback Island (RM 310.8) (Figure 35), with the following exceptions: continuous open leads, one-quarter to one-third of the river width, were observed within the Ouray National Wildlife Refuge (RM 251.3-254), along Hamacker Bottom (RM 270-276.4), near Collier Draw (RM 286.5-287.2), and near Bonanza Bridge (RM 288.8-289.8). In the remaining reaches, isolated, discontinuous leads were fairly common, but they accounted for only a small portion of the total ice-covered area. Between RM 310.8 and 314.5 the river made a gradual transition from a complete ice cover to open water (Figure 35). An ice jam $90-\mathrm{m}$ long was observed on 24 January 1997 in the bend below Chew Bridge at RM 316.3. No ice was observed from the Chew Bridge to the confluence of the Yampa River and it is likely that the main channel of the Green River was open to Flaming Gorge Dam. No floating frazil was observed from Split Mountain Campground to Chew Bridge during 23-30 January. Air temperatures in the study reach moderated during 25-28 January 1997 and the snow and ice around the edges of open leads was wet. Shoreline cracks were also wet in places, indicating that melting of the ice cover was occurring.

An aerial inspection on the afternoon of 28 January, approximately 3 days after the propagation waves associated with peaking operations at Flaming Gorge Dam had started passing through the study reach, revealed that the small ice jam below Chew Bridge had broken up and that the leading edge of the ice cover had moved from RM 310.8 to RM 309.8. Surveys of ice cover distribution from 29-30 January found that the stationary ice cover had retreated to RM 306 (Figure 36). Otherwise, ice conditions appeared similar to the conditions that existed on 25 January (Figure 35). Based on these observations, the movement of the location of the leading edge of the ice cover occurred in two stages: the first movement was from RM 310.8 to RM 309.8 by 1500 hours on 28 January 1997, and the second was movement of the leading edge from RM 309.8 to RM 306 early on 29 January. The ice motion detector at RM 308.2 indicated that the ice cover at that location broke up at 0600 hours on 29 January. A team arrived at this location five hours later to find an open channel with small ice pieces and floes floating past. The post-breakup water level was approximately $1.2 \mathrm{~m}$ lower (based upon examination of the location of the shear walls of ice remaining along the shoreline [White and Zufelt, 1994]) than the pre-breakup ice surface elevation, attributable to the increased conveyance of the river after removal of complete ice cover. One mile downstream, between RM 307.2 and RM 306.0, the river made a gradual transition from completely open to entirely ice covered. There was little ice debris at the leading edge location at RM 306.0, so ice pieces had either melted in transit or had been carried beneath the upstream edge of the ice cover. Within this transition reach, at 1140 hours on 29 January, a 100-ft-long ice jam spanned the open portion of the channel at RM 307.0. Floes colliding with the upstream edge of the jam, passed beneath the accumulation, and emerged at the downstream end. Downstream of the new leading edge location (RM 306.0) the condition of the ice cover appeared unchanged from conditions that existed during the steady flow observations made on 23-25 January.

During a subsequent aerial inspection of the study reach on 20 February 1997, it was 
observed that most of the ice cover present in late January had released or melted. The ice motion detector located above the Bonanza Bridge (RM 290.4) recorded the timing of the ice release to be 0335 hours on 5 February 1997. The detector located within the Ouray National Wildlife Refuge failed to properly record the time of ice breakup.

\subsection{6-1997 FIELD MEASUREMENTS}

Ice thickness and river depth data for the individual points on cross sections are shown in the Appendix. In the downstream portion of the study reach, from the Jensen Bridge to the Ouray Bridge, roughly half of the channel area was composed of juxtaposed frazil pans and floes while the remaining area was thermally grown sheet ice. From the Jensen Bridge to Razorback Island the channel gradient was steeper and the ice cover was rougher, consisting primarily of juxtaposed frazil pans and floes, as well as unconsolidated (loose) frazil (especially in the three upstream-most locations).

The thickness of the ice during the field study ranged from approximately 9 to $109 \mathrm{~cm}$ (Table 4, Figure 37). The three greatest values for ice thickness occurred in the three upstreammost sites prior to initiation of fluctuating flows, but the ice cover represented by these three measurements consisted of thin layers (approximately $5-10 \mathrm{~cm}$ ) of solid ice cover underlaid by a thick layer of unconsolidated frazil. The three upstream-most locations no longer had intact ice covers during the post-fluctuation measurement period and a statistical comparison of pre- and post- peaking ice thickness measurements was not possible for these sites. For the remaining cross sections, there was no significant difference in mean ice thickness among sections and there was no significant difference in the mean thickness of the ice cover before and after initiation of peaking flows (Table 5).

Figure 38 presents measurements of stage changes of water and ice surfaces under the fluctuating flow regime for seven locations within the study area. The stage changes at the Chew, Jensen, Bonanza, and Ouray bridges were for the surface of the open water that was present under each of the bridges, whereas the stage changes at Dinosaur Bend, Horseshoe Bend, and the Ouray Hatchery were for changes in the elevation of the ice surface as the propagation wave passed underneath. The magnitude of the stage changes ranged from approximately $24 \mathrm{~cm}$ at the Jensen Bridge to $6 \mathrm{~cm}$ at the Ouray Bridge.

Note that for the two upstream-most stations (Chew Bridge and Dinosaur Bend) the complete ascending limb of the stage hydrograph was obtained, but not a complete descending limb (Figure 38). The original study design for the change from steady to fluctuating releases at Flaming Gorge Dam called for a downramp to $800 \mathrm{cfs}$ followed by an upramp to 3,000 cfs (a $2,200 \mathrm{cfs}$ change). Under this scenario, the field team planned to obtain data on the first ascending limb for each of the stage measurement stations, thereby observing a maximum stage 
change. However, due to miscommunication at the power scheduling office, the upramp portion of the first peaking cycle at Flaming Gorge Dam went from approximately 1,500 cfs to 3,000 cfs, a 1,500 cfs change. After the error was identified, the field sampling was modified to measure the fluctuations associated with the first decrease in dam releases from $3,000 \mathrm{cfs}$ to $800 \mathrm{cfs}$ at the five remaining stage measurement locations, although it was too late to measure the same wave at the two upper-most stations. The stage change for Chew Bridge and Dinosaur Bend would undoubtedly have been larger if the stage changes associated with the descending limb of the first peaking cycle had been measured.

\subsection{MODELING RESULTS}

The extent of ice cover predicted by the ice process model for the winter of 1989-1990 through the winter of 1995-1996 is shown in Figures 39-45, along with the measured daily average air temperature for Vernal, Utah. Modeled results were in general agreement with the historical ice observations. The model predicted formation of a stationary ice cover in the Green River every winter and indicated that the ice cover progressed upstream relatively quickly during cold periods. The modeled ice cover progressed upstream as far as RM 300 almost every winter. However, there was a large variation in the length of time each winter that the ice cover was predicted to remain at this location. During colder winters it was predicted that the ice cover would extend past RM 300 for several months. During milder winters, the ice cover would extend past RM 300 for two weeks or less.

\subsection{RIVER HYDRAULIC CONDITIONS: COMPARISON OF STEADY AND UNSTEADY FLOWS}

Using the unsteady flow model described in Section 2.4.1, the hydraulic parameters of flow depth, flow velocity, and Froude number throughout the Green River study reach were compared under the steady and fluctuating flows that occurred during the 1997 field study. The results for steady flow are listed in Table 6. At the end of the steady flow period, the releases from Flaming Gorge Dam were fluctuated in a typical peaking hydropower pattern and the resulting flows passed through the study reach in a series of peaks and troughs (Figure 18). Hydraulic parameters were estimated for the first peak (Table 7), the first trough (Table 8), the lowest recorded trough (Table 9), and the highest recorded peak (Table 10). The variation in depth between the steady and the fluctuating flows was smallest downstream of RM 280 $(+/-3 \mathrm{~cm})$, moderate between RM 280 and $300(+/-8 \mathrm{~cm})$, and largest between RM 300 and 316 $(+/-30 \mathrm{~cm})$. There was a difference in flow velocity of about \pm 5 percent between the steady and fluctuating flows downstream of RM 302 and \pm 15 percent between RM 300 and 316 . The change in Froude number (a measure of the hydraulic forces affecting ice formation and breakup) between the steady and the fluctuating flows was \pm 0.05 downstream of RM 300 and 
\pm 0.2 between RM 300 and RM 316 . Thus, it appears that the influence of fluctuating flows would be greatest in the reach of river upstream of about RM 300 . In general, it is expected that the influence of peaking operations at Flaming Gorge Dam would decrease in the downstream direction due to the subsidence of flood waves as they propagate over distances. This subsidence is caused largely by channel friction as the wave propagates, but other factors can also play a role (Henderson 1966). Given the small effect of the fluctuating flows on the hydraulic properties as measured by the Froude number downstream of RM 300, the influence of fluctuating flows on ice cover thickness and roughness should be small downstream of this point. 


\section{DISCUSSION}

This study was a detailed investigation of the ice processes on the Green River downstream of Flaming Gorge Dam. The overall goal of the study was to assess the influence of the daily release schedule of Flaming Gorge Dam on the river ice processes in the study reach in order to evaluate the potential for impacts to overwintering endangered fish. The first step was to analyze historical measurements of water temperature, air temperature, and ice observations. The water temperature entering the study reach near the Jensen gage and just upstream of the Chew Bridge was often at $0{ }^{\circ} \mathrm{C}$ during the winter, and the daily average air temperatures were consistently below $0{ }^{\circ} \mathrm{C}$ throughout December, January, and most of February. Ice was observed in the Green River study reach during every winter for which reliable records were available. The USGS observations of ice, made in conjunction with retrieval of discharge measurements from the Jensen gage, were confounded by the retrieval schedule and were not reliable indicators of ice presence.

Formation of ice cover in the Green River study reach followed a consistent pattern each winter for which records were available and the daily release schedule of Flaming Gorge Dam, whether steady or fluctuating as a result of hydropower demand, did not appear to affect the basic outline of this pattern (Table 11). The initial ice observed each winter was frazil ice, transported at the water surface in the form of slush, floes, and pancake ice. A stationary ice cover formed initially near the Ouray Bridge and then progressed upstream. The ice cover was formed primarily by the juxtaposition of floes up to RM 290. Underturning of ice floes and a rougher ice surface seem to be more typical upstream of this point. The upstream extent of the ice cover was typically reported to be at least RM 302 and often extended upstream of this point. No ice cover progression has been reported between Chew Bridge (RM 316) and Split Mountain, except for short, isolated stretches during a particularly severe winter, probably as a result of the steeper gradient between Chew Bridge and the downstream end of Split Mountain.

Analysis of the 1997 field survey data and modeling of hydraulic conditions indicated that daily fluctuations in releases from Flaming Gorge Dam have only a small effect on the hydraulic conditions in the Green River downstream of RM 300 (Jensen Bridge). Consequently, daily fluctuations are unlikely to significantly affect the formation or breakup of ice covers further downstream. The results indicated that the fluctuations would be more pronounced and could affect the formation and breakup of ice cover upstream of RM 300 .

The general trend of ice cover formation in the Green River can be outlined based upon historical observations, the 1996-97 field surveys, and the historical water and air temperature data. First, construction of Flaming Gorge Dam undoubtedly had an influence on the ice regime downstream of the dam. A primary influence of the dam was to increase the river water temperature immediately downstream of the dam during winter. Winter stratification of the reservoir causes colder, less dense water to overlay warmer, more dense water (pure water is 
densest at approximately $4{ }^{\circ} \mathrm{C}$ ) throughout the winter. This warmer water comprises part or all of the wintertime releases and, as a result, the release temperature rarely drops below $4{ }^{\circ} \mathrm{C}$ in the winter. The net effect of these warm releases is to keep the river immediately downstream of the dam free of ice throughout the winter. Water released during the winter cools as it travels downstream and the influence of the release of warmer water lessens with increasing downstream distance. The length of the reach influenced by Flaming Gorge Dam depends on the rate of the heat transfer from the water surface, with the distance inversely proportional to the heat transfer rate. If the temperature of water entering the study reach is at $0^{\circ} \mathrm{C}$, as is often the case throughout the winter, it is clear that the influence of Flaming Gorge Dam on the river water temperature is no longer evident at this point.

Frazil ice was reported in the Green River study reach during every year for which records are available. This ice was observed at the water surface, in the form of slush, flocs, and pancake ice that was transported downstream. The stationary ice cover that forms in the Green River study reach is composed largely of this frazil ice. The ice cover bridging location at the downstream limit of the study area was consistently observed to be in the area of Ouray Bridge or beyond. The stationary ice cover progressed upstream from this point during each winter, consistently reaching between RM 302 and about RM 316. The extreme upstream limit of the stationary ice covers was at the Chew Bridge (RM 316). This is the downstream end of a steep gradient reach and it is unlikely that ice-cover in the study reach would progress upstream of this point in most mild and moderate winters due to the high flow velocity in the channel. It is interesting to note that the maximum upstream ice cover extent on the Green River only varied by about 14 miles (RM 302-RM 316) even though the maximum AFDDs recorded during the winters varied widely. There are two reasons for this: (1) the ice cover consistently bridges at or near the Ouray Bridge each winter (RM 248), and (2) the ice cover progresses upstream very quickly during periods of cold weather. The ice cover progresses upstream largely through juxtaposition from the Ouray Bridge (RM 248) to the Bonanza Bridge (RM 290). Upstream of Bonanza Bridge, the ice cover progresses largely through juxtaposition with some underturning of the ice floes. The tendency of the floes to underturn increases as the ice cover progresses further upstream from Bonanza Bridge because flow velocity and Froude number increase.

During the winter of 1987-1988, layers of frazil ice were observed beneath the stationary ice cover in the reach from RM 305 to RM 316 (Valdez and Masslich 1989). This is the only winter season for which such extensive frazil ice deposits were reported. This was also the harshest winter, as measured by AFDDs, for which ice observations are available. It is likely that the intense cold of this winter season resulted in tremendous amounts of frazil ice being produced upstream of the study reach. The frazil ice was probably carried beneath the stationary ice cover which was prevented from progressing upstream beyond the Chew Bridge due to the steep gradient of the river. This frazil ice was deposited beneath the ice cover throughout the reach immediately downstream of the leading edge of the cover, RM 305 to RM 316. Under the meteorologic and flow conditions that occurred during the 1997 field study, there was no 
significant thickening of the ice cover after fluctuating flows were initiated and after the upstream portion of the ice cover broke up, indicating that there was no significant deposition of frazil under the leading portion of the ice cover.

It is interesting to note that the daily release schedule of Flaming Gorge Dam does not seem to have a very large influence on the overall pattern of ice formation in the study reach of the Green River except for the maximum extent of the ice cover. Even this difference is relatively small, and varied only between River Mile 302 and 316 (Table 11) for studies that made reliable observations of ice cover extent. The maximum documented extent of the ice cover occurred during the winter of 1987-1988 (ice cover progressed upstream as far as Chew Bridge, RM 316), a winter during which fluctuating flows were in effect at Flaming Gorge Dam (Valdez and Masslich 1989). It was also during this winter that exceptionally thick ice covers were observed in the reach from RM 305 to RM 316 due to frazil ice deposition beneath the cover. It is likely that the daily fluctuating flows produced velocities capable of transporting the frazil ice produced upstream beneath the ice cover in this reach. The mean daily flow at the Jensen gage during the winter of $1987-1988$ was $2,701 \mathrm{cfs}$, with a range of 1,470 to $3,700 \mathrm{cfs}$. During winters when the flow was held steady, such as 1994-1995 and 1996-1997, the flow velocities were not great enough to cause substantial transport of frazil ice beneath the ice cover. However, during years when the flows were held steady, ice cover progressed upstream only as far as River Mile 310.8. Apparently flow velocity is too high upstream of this location to allow the ice cover to progress unless the cover is exceptionally strong. The deposition of frazil ice beneath the ice cover would cause the ice cover to be thicker and ultimately stronger. In addition, the very thick ice covers formed through frazil deposition would reduce conveyance and cause a "backwater effect," thereby reducing the velocity in areas directly upstream. For these reasons, ice cover formed during fluctuating flows could progress upstream of River Mile 310.8 when large quantities of frazil ice are available. However, it appears unlikely that any substantial ice cover can develop within the study reach upstream of Chew Bridge. Ice covers do form in some upstream areas outside the study reach (e.g., Island Park and Rainbow Park) during some winters.

The breakup of the stationary ice cover in the study reach of the Green River appears to occur largely as the result of thermal meltout due to water temperatures above $0{ }^{\circ} \mathrm{C}$ and mild air temperatures. For example, meltout rates of 1 river mile per day were observed downstream of Bonanza Bridge during the 1987-1988 winter (Valdez and Masslich 1989). Often relatively short sections of the ice cover were observed to break up and move out more or less simultaneously during periods when melting was occurring. No ice covers have been reported to last past late March.

The primary result of daily fluctuations would be to transport frazil ice beneath the ice cover in the reach above the Jensen Bridge. As the cover progresses upstream above Jensen Bridge, the deposition of frazil ice caused by the daily fluctuations would result in an ice cover 
thicker than would develop in this reach under steady flow. Main channel frazil ice depositions up to $90 \mathrm{~cm}$ thick occurred an 11-mile reach (RM 305 to RM 316) during the winter of 1987-1988 when fluctuating releases were being made from Flaming Gorge Dam. The ice cover that formed in the same reach during steady releases from Flaming Gorge Dam had a mean thickness of about $24 \mathrm{~cm}$ during the 1997 study, although this was also a milder winter than during 1987-1988. The upstream five miles of ice cover broke up during the 1997 field study, shortly after releases from Flaming Gorge Dam began fluctuating on a daily basis. Apparently, the ice cover was not strong enough to resist the increase in hydraulic stress caused by the fluctuations in this reach.

Operations of Flaming Gorge Dam that take frazil production and the upstream extent of the ice cover into account could reduce the likelihood that daily fluctuations would affect ice formation, ice breakup, or the transport and deposition of frazil ice beneath the ice cover in main channel areas used by overwintering endangered fishes (i.e., areas downstream of the Jensen Bridge). To avoid deposition of large quantities of frazil beneath a stationary ice cover, large daily fluctuations at the Jensen gage should be avoided during extremely cold weather (e.g., mean daily air temperatures of about $-7^{\circ} \mathrm{C}$ or less) until surface ice cover has progressed approximately 10 river miles upstream of the Jensen Bridge (RM 310). Under such operations, it is unlikely that frazil ice would be deposited farther than approximately the Jensen Bridge area and this should protect areas farther downstream that are used by the majority of overwintering adult Colorado pikeminnow and razorback suckers. Under these conditions, ice cover would be extended upstream of the Jensen Bridge within a few days and fluctuations could be resumed. During less severe weather, when frazil production is reduced, the likelihood of depositing large quantities of frazil beneath surface ice is also reduced. In such cases, operations that approximate those seen during the field study of 1996-1997 would not result in significant deposition of frazil ice under the stationary ice cover and would be unlikely to affect breakup of all but the thinnest ice covers past about RM 300 (Jensen Bridge).

A numerical model of dynamic ice formation in the Green River was developed and used to simulate the ice cover formation on the Green River for the winters 1989-1990 through 1995-1996. The ice model results were in general agreement with the historical ice observations and indicated the model could be used to evaluate the condition of the ice cover in the study area of the Green River under a given set of meteorological and hydrological conditions. However, collection of additional data pertaining to ice formation and breakup in the Green River would be useful for improving calibration of the flow and ice formation sub-models and would also allow the results of the model to be validated. We recommend that accurate water temperature data be collected during winter within the study reach. Such information would be necessary for future improvements to the ice process models and would provide information about the environmental conditions that endangered fishes encounter within the study reach.

Our results indicated that daily hydropower operations at Flaming Gorge Dam have little 
appreciable effect on ice processes downstream of the Jensen Bridge (RM 300). This suggests that daily fluctuations from hydropower generation at Flaming Gorge Dam do not appreciably affect main channel ice formation and breakup in portions of the Green River containing the primary nursery areas for Colorado pikeminnow and used by overwintering adult Colorado pikeminnow and razorback suckers. While Flaming Gorge Dam is unlikely to be responsible for changes in ice conditions encountered by Colorado pikeminnow and razorback suckers in main channel habitats, we advise caution in reaching the conclusion that unrestricted wintertime dam operations will not detrimentally affect age- 0 Colorado pikeminnow. Backwater habitats used as nursery habitats by age- 0 fish are susceptible to inundation and desiccation because they are shallow and are formed behind low-lying sand berms that may be overtopped at higher flows. The degree to which young endangered fish use these habitats during winter is not known and additional investigations during winter are recommended in order to better understand the full array of conditions faced by fish during their first year of life. 


\section{RECOMMENDATIONS}

1. To prevent ice breakup, or the transport and deposition of frazil ice in areas used by overwintering endangered fishes, large daily fluctuations at the Jensen gage should be avoided during extremely cold weather (mean daily air temperature about $-7^{\circ} \mathrm{C}$ or below) until surface ice has formed to approximately RM 310. During milder winters, when frazil ice production is reduced, less restrictive operations could occur without depositing frazil ice under the ice cover and without breaking up all but the thinnest ice covers past about RM 300 (Jensen Bridge). During the 1997 field study the mean daily flow at the Jensen gage was approximately $2,440 \mathrm{cfs}$ and fluctuated daily between 1,700 and 3,500 cfs. These fluctuations did not deposit significant amounts of frazil under the ice cover and did not break up the ice cover downstream of RM 306.

2. Collect accurate hourly water temperatures at a number of locations throughout the study reach to improve calibration of the ice-process model and to test specific assumptions in the model (e.g., timing of the formation of frazil ice). To accomplish this, measurements accurate to the nearest $0.1^{\circ} \mathrm{C}$ would be useful. Additional temperature information would provide information about the environmental conditions (such as supercooled water) that endangered fishes may encounter within the study reach. Collection of temperature data in other portions of the river could be used to investigate the distance to which Flaming Gorge Dam exerts a thermal influence on the river and the effects of fluctuating flows on temperature regimes.

3. Additional investigations should be conducted to characterize winter conditions in backwaters and other low-velocity habitats that may serve as overwintering areas for juvenile endangered fishes. Although such studies were conducted in backwater areas by Valdez and Cowdell (1999), the winters during those studies were unusually mild. Although main channel ice processes in the principal area used by overwintering native fishes do not appear to be greatly affected by fluctuating flows, shallower backwater areas used as nursery habitats by age- 0 fish may be susceptible to inundation and desiccation. Consequently, the degree of use of these areas during winter and the physical conditions within such areas should be examined. 


\section{REFERENCES}

Ashton, G. D. 1986. River and Lake Ice Engineering. Water Resources Publications, Littleton, Colorado.

Beltaos, S. (editor). 1995. River Ice Jams. Water Resources Publications, Highlands Ranch, Colorado.

Chow, V. T. 1964. Handbook of Applied Hydrology. McGraw-Hill, New York.

Cunge, J.A., F. M. Holly, and A. Verway. 1980. Practical Aspects of Computational River Hydraulics. Institute of Hydraulic Research, University of Iowa, Iowa City, Iowa.

Daly, S.F. (editor). 1994. Report on Frazil Ice. USACRREL Special Report 94-23, Cold Regions Research and Engineering Laboratory, U.S. Army Corps of Engineers, Hanover, New Hampshire.

Daly, S.F. In prep. Forecasting River Ice. Ph.D. Dissertation. University of Iowa, Iowa City, Iowa.

FLO Engineering, Inc. 1996. Green River Flooded Bottomlands Investigation. Ouray Wildlife Refuge and Canyonlands National Park, Utah. Recovery Implementation Program for Endangered Fish Species in the Upper Colorado Basin, U.S. Fish and Wildlife Service, Denver, Colorado.

Henderson, F.M. 1966. Open Channel Flow. Macmillan Publishing Co., New York City.

Lal, A.M.W., and H.T. Shen. 1993. A Mathematical Model for River Ice Processes. USACRREL Report 93-4, Cold Regions Research and Engineering Laboratory, U.S. Army Corps of Engineers, Hanover, New Hampshire.

Panofsky, H. A., and G. W. Brier. 1968. Some Applications of Statistics to Meteorology. College of Earth and Mineral Sciences, Penn State University, University Park, Pennsylvania.

SAS. 1985. SAS User's Guide: Statistics, Version 5 Edition. SAS Institute, Inc., Cary, North Carolina.

Shen, H.T., G. Bjedov, S.F. Daly, and A.M.W. Lal. 1991. Numerical Model for Forecasting Ice Conditions on the Ohio River. USACRREL Report 91-16, Cold Regions Research and Engineering Laboratory, U.S. Army Corps of Engineers, Hanover, New Hampshire. 
Sokal, R.R., and F.J. Rohlf. 1981. Biometry. W.H. Freeman and Co., New York City.

U. S. Army. 1990. HEC-2 Users Manual. U.S. Army Hydrologic Engineering Center, Davis, California.

U. S. Army. 1995. UNET Users Manual. US Army Hydrologic Engineering Center, Davis, California.

U.S. Fish and Wildlife Service. 1992. Final Biological Opinion for the Operation of Flaming Gorge Dam. U.S. Fish and Wildlife Service, Mountain-Prairie Region, Denver, Colorado.

Valdez, R., and B. Cowdell. 1999. Effects of Flow Regulation and Ice Processes on Overwinter Nursery Habitat of Age-0 Colorado Pikeminnow in the Green River Below Flaming Gorge Dam. Final Report, Study No. FG-10, Recovery Implementation Program for Endangered Fish Species in the Upper Colorado Basin, U.S. Fish and Wildlife Service, Denver, Colorado.

Valdez, R., and W. Masslich. 1989. Winter Habitat Study of Endangered Fish - Green River: Wintertime Movement and Habitat of Adult Colorado Squawfish and Razorback Suckers. Contract No. 6-CS-40-04490, U.S. Bureau of Reclamation, Salt Lake City, Utah.

White, K.D., and J.E. Zufelt. 1994. Ice Jam Data Collection. USACRREL Special Report 94-7, Cold Regions Research and Engineering Laboratory, U.S. Army Corps of Engineers, Hanover, New Hampshire.

Yin, S.C.L., J.J. McCoy, S.C. Palmer, and H.E. Cho. 1995. Effects of Flaming Gorge Dam Hydropower Operations on Flow and Stage in the Green River, Utah and Colorado. Environmental Assessment Division, Argonne National Laboratory, Argonne, Illinois. 
TABLES

$-30-$ 
Table 1. Calibration data used in the unsteady flow UNET model.

\begin{tabular}{|c|c|c|c|c|c|c|}
\hline $\begin{array}{l}\text { Cross } \\
\text { Section } \\
(\mathbf{R M})\end{array}$ & $\begin{array}{l}\text { Thalweg } \\
\text { Elevation } \\
\text { (ft MSL) }\end{array}$ & $\begin{array}{c}\text { Water } \\
\text { Surface } \\
\text { Elevation } \\
\text { (ft MSL) }\end{array}$ & $\begin{array}{c}\text { Ice } \\
\text { Thickness } \\
\text { (cm) }\end{array}$ & $\begin{array}{l}\text { Channel Bed } \\
\text { Roughness } \\
\text { (Manning's n) }\end{array}$ & $\begin{array}{c}\text { Ice Cover } \\
\text { Roughness } \\
\text { (Manning's } \boldsymbol{n} \text { ) }\end{array}$ & $\begin{array}{c}\text { Cross } \\
\text { Section } \\
\text { Type }^{1}\end{array}$ \\
\hline 246.00 & 4637.9 & 4646.3 & 21 & 0.035 & 0.025 & E \\
\hline 248.00 & 4638.2 & 4646.3 & 21 & 0.035 & 0.025 & $S$ \\
\hline 248.53 & 4640.5 & 4647.8 & 21 & 0.028 & 0.025 & $S$ \\
\hline 249.04 & 4640.9 & 4649.1 & 21 & 0.024 & 0.025 & $S$ \\
\hline 249.56 & 4646.3 & 4650.9 & 21 & 0.032 & 0.025 & $\mathrm{~S}$ \\
\hline 249.85 & 4639.1 & 4651.3 & 21 & 0.024 & 0.025 & $S$ \\
\hline 250.62 & 4641.5 & 4651.7 & 21 & 0.024 & 0.025 & $\mathrm{~s}$ \\
\hline 251.38 & 4637.7 & 4652.1 & 21 & 0.024 & 0.025 & $S$ \\
\hline 252.12 & 4646.6 & 4653.3 & 21 & 0.036 & 0.025 & $\mathrm{~S}$ \\
\hline 252.40 & 4638.9 & 4653.6 & 21 & 0.024 & 0.025 & $\mathrm{~S}$ \\
\hline 252.71 & 4646.7 & 4653.8 & 21 & 0.032 & 0.025 & $\mathrm{~S}$ \\
\hline 253.11 & 4645.1 & 4654.3 & 21 & 0.032 & 0.025 & $S$ \\
\hline 253.43 & 4649.3 & 4654.8 & 21 & 0.036 & 0.025 & $S$ \\
\hline 253.82 & 4647.4 & 4655.5 & 21 & 0.036 & 0.025 & $S$ \\
\hline 254.16 & 4652.2 & 4656.3 & 21 & 0.032 & 0.025 & $\mathrm{~S}$ \\
\hline 254.62 & 4649.1 & 4657.5 & 21 & 0.036 & 0.025 & $S$ \\
\hline 255.00 & 4648.0 & 4657.9 & 21 & 0.036 & 0.025 & $S$ \\
\hline 255.38 & 4649.1 & 4658.3 & 21 & 0.036 & 0.025 & $S$ \\
\hline 255.66 & 4652.2 & 4658.6 & 21 & 0.024 & 0.025 & $\mathrm{~S}$ \\
\hline 256.22 & 4649.0 & 4659.0 & 21 & 0.024 & 0.025 & $\mathrm{~S}$ \\
\hline 256.65 & 4653.1 & 4659.5 & 21 & 0.028 & 0.025 & $\mathrm{~S}$ \\
\hline 257.06 & 4649.2 & 4660.0 & 21 & 0.032 & 0.025 & $S$ \\
\hline 257.60 & 4654.1 & 4660.8 & 21 & 0.036 & 0.025 & $S$ \\
\hline 258.01 & 4651.2 & 4661.3 & 21 & 0.024 & 0.025 & $S$ \\
\hline 258.32 & 4653.2 & 4661.5 & 21 & 0.024 & 0.025 & $S$ \\
\hline 258.59 & 4655.3 & 4662.0 & 21 & 0.029 & 0.025 & $S$ \\
\hline 259.10 & 4650.4 & 4662.5 & 21 & 0.024 & 0.025 & $S$ \\
\hline 259.25 & 4652.9 & 4662.6 & 21 & 0.032 & 0.025 & $\mathrm{~S}$ \\
\hline 259.72 & 4645.0 & 4662.7 & 21 & 0.032 & 0.025 & $S$ \\
\hline 260.26 & 4653.4 & 4662.9 & 21 & 0.036 & 0.025 & $S$ \\
\hline
\end{tabular}


Table 1. Continued.

\begin{tabular}{|c|c|c|c|c|c|c|}
\hline $\begin{array}{l}\text { Cross } \\
\text { Section } \\
\text { (RM) }\end{array}$ & $\begin{array}{l}\text { Thalweg } \\
\text { Elevation } \\
\text { (ft MSL) }\end{array}$ & $\begin{array}{l}\text { Water } \\
\text { Surface } \\
\text { Elevation } \\
\text { (ft MSL) }\end{array}$ & $\begin{array}{c}\text { Ice } \\
\text { Thickness } \\
\text { (cm) }\end{array}$ & $\begin{array}{c}\text { Channel Bed } \\
\text { Roughness } \\
\text { (Manning's } n \text { ) }\end{array}$ & $\begin{array}{c}\text { Ice Cover } \\
\text { Roughness } \\
\text { (Manning's } n \text { ) }\end{array}$ & $\begin{array}{c}\text { Cross } \\
\text { Section } \\
\text { Type }\end{array}$ \\
\hline 260.61 & 4656.1 & 4663.4 & 21 & 0.036 & 0.025 & $S$ \\
\hline 261.06 & 4659.3 & 4664.4 & 21 & 0.036 & 0.025 & S \\
\hline 262.13 & 4659.3 & 4666.6 & 21 & 0.036 & 0.025 & $S$ \\
\hline 262.61 & 4659.2 & 4667.0 & 21 & 0.024 & 0.025 & $S$ \\
\hline 263.13 & 4660.2 & 4667.6 & 21 & 0.032 & 0.025 & $S$ \\
\hline 263.75 & 4657.8 & 4668.3 & 21 & 0.024 & 0.025 & $S$ \\
\hline 264.16 & 4662.3 & 4668.8 & 21 & 0.036 & 0.025 & $S$ \\
\hline 265.50 & 4665.1 & 4671.8 & 21 & 0.036 & 0.025 & $\mathrm{~S}$ \\
\hline 268.50 & 4667.0 & 4674.3 & 21 & 0.036 & 0.025 & $\mathrm{~S}$ \\
\hline 270.80 & 4671.0 & 4677.5 & 21 & 0.036 & 0.025 & $\mathrm{E}$ \\
\hline 273.00 & 4675.0 & 4681.3 & 21 & 0.036 & 0.025 & $\mathrm{E}$ \\
\hline 275.00 & 4680.0 & 4684.9 & 21 & 0.036 & 0.025 & E \\
\hline 277.30 & 4683.5 & 4689.1 & 21 & 0.036 & 0.025 & $\mathrm{E}$ \\
\hline 279.40 & 4682.5 & 4691.3 & 21 & 0.036 & 0.025 & E \\
\hline 282.00 & 4687.0 & 4694.4 & 21 & 0.036 & 0.025 & $\mathrm{E}$ \\
\hline 283.50 & 4690.8 & 4697.9 & 21 & 0.036 & 0.025 & E \\
\hline 284.50 & 4693.0 & 4699.3 & 21 & 0.036 & 0.025 & $\mathbf{E}$ \\
\hline 285.41 & 4692.0 & 4700.4 & 21 & 0.036 & 0.025 & $S$ \\
\hline 286.50 & 4693.5 & 4701.6 & 21 & 0.036 & 0.025 & $\mathrm{E}$ \\
\hline 287.90 & 4695.5 & 4703.3 & 21 & 0.036 & 0.025 & $\mathrm{E}$ \\
\hline 289.54 & 4691.0 & 4703.4 & 21 & 0.036 & 0.025 & $\mathrm{~s}$ \\
\hline 290.40 & 4697.0 & 4703.9 & 21 & 0.036 & 0.025 & $\mathrm{E}$ \\
\hline 292.10 & 4700.0 & 4706.2 & 21 & 0.036 & 0.025 & $\mathrm{E}$ \\
\hline 294.00 & 4705.0 & 4709.6 & 21 & 0.036 & 0.025 & $\mathrm{E}$ \\
\hline 295.80 & 4707.5 & 4713.7 & 21 & 0.036 & 0.025 & $E$ \\
\hline 297.70 & 4709.5 & 4716.3 & 21 & 0.036 & 0.025 & $\mathrm{E}$ \\
\hline 299.70 & 4713.0 & 4719.1 & 21 & 0.036 & 0.025 & E \\
\hline 301.30 & 4715.0 & 4721.8 & 21 & 0.036 & 0.025 & $\mathrm{E}$ \\
\hline 302.30 & 4712.0 & 4722.4 & 24 & 0.036 & 0.030 & $\mathrm{E}$ \\
\hline
\end{tabular}


Table 1. Continued.

\begin{tabular}{|c|c|c|c|c|c|c|}
\hline $\begin{array}{l}\text { Cross } \\
\text { Section } \\
(\mathrm{RM})\end{array}$ & $\begin{array}{c}\text { Thalweg } \\
\text { Elevation } \\
\text { (ft MSL) }\end{array}$ & $\begin{array}{c}\text { Water } \\
\text { Surface } \\
\text { Elevation } \\
\text { (ft MSL) }\end{array}$ & $\begin{array}{c}\text { Ice } \\
\text { Thickness } \\
\text { (cm) }\end{array}$ & $\begin{array}{l}\text { Channel Bed } \\
\text { Roughness } \\
\text { (Manning's } n \text { ) }\end{array}$ & $\begin{array}{c}\text { Ice Cover } \\
\text { Roughness } \\
\text { (Manning's } n \text { ) }\end{array}$ & $\begin{array}{c}\text { Cross } \\
\text { Section } \\
\text { Type }\end{array}$ \\
\hline 303.90 & 4721.0 & 4723.6 & 24 & 0.036 & 0.030 & $\mathrm{E}$ \\
\hline 304.69 & 4721.5 & 4728.7 & 24 & 0.036 & 0.030 & $S$ \\
\hline 304.81 & 4721.3 & 4729.1 & 24 & 0.036 & 0.030 & $S$ \\
\hline 305.01 & 4722.4 & 4729.7 & 24 & 0.036 & 0.030 & $S$ \\
\hline 305.42 & 4722.6 & 4730.7 & 24 & 0.036 & 0.030 & $\mathrm{~S}$ \\
\hline 305.74 & 4724.4 & 4731.2 & 24 & 0.036 & 0.030 & $S$ \\
\hline 305.82 & 4724.4 & 4731.3 & 24 & 0.036 & 0.030 & $S$ \\
\hline 306.18 & 4724.9 & 4731.8 & 24 & 0.036 & 0.030 & $\mathrm{~S}$ \\
\hline 306.30 & 4722.4 & 4731.9 & 24 & 0.036 & 0.030 & $S$ \\
\hline 306.63 & 4723.9 & 4732.3 & 24 & 0.036 & 0.030 & $S$ \\
\hline 306.90 & 4725.0 & 4732.7 & 24 & 0.036 & 0.030 & $\mathrm{E}$ \\
\hline 307.10 & 4722.8 & 4733.1 & 24 & 0.036 & 0.030 & $S$ \\
\hline 307.31 & 4726.3 & 4733.5 & 24 & 0.036 & 0.030 & $S$ \\
\hline 308.11 & 4728.2 & 4734.8 & 24 & 0.036 & 0.030 & $S$ \\
\hline 308.71 & 4727.5 & 4735.8 & 24 & 0.036 & 0.030 & $\mathrm{~S}$ \\
\hline 309.27 & 4730.9 & 4737.2 & 24 & 0.036 & 0.030 & $S$ \\
\hline 310.00 & 4732.5 & 4739.1 & 24 & 0.036 & 0.030 & $S$ \\
\hline 310.59 & 4733.7 & 4740.3 & 24 & 0.036 & 0.030 & S \\
\hline 310.89 & 4733.7 & 4741.2 & 24 & 0.036 & 0.030 & $S$ \\
\hline 310.95 & 4734.7 & 4741.4 & 24 & 0.036 & 0.030 & $\mathrm{~S}$ \\
\hline 311.04 & 4733.5 & 4741.7 & 24 & 0.036 & 0.030 & s \\
\hline 311.18 & 4736.3 & 4742.2 & 24 & 0.036 & 0.030 & $S$ \\
\hline 311.50 & 4738.6 & 4743.7 & 24 & 0.036 & 0.030 & $S$ \\
\hline 311.68 & 4735.7 & 4744.2 & open water & 0.036 & & $S$ \\
\hline 312.40 & 4739.0 & 4744.9 & open water & 0.036 & & $\mathrm{E}$ \\
\hline 313.40 & 4743.0 & 4747.2 & open water & 0.036 & & $\mathrm{E}$ \\
\hline 314.50 & 4749.0 & 4753.7 & open water & 0.036 & & E \\
\hline 316.60 & 4756.1 & 4761.4 & open water & 0.036 & & $\mathrm{E}$ \\
\hline
\end{tabular}

${ }^{1} S$ indicates that the elevation of the cross section was surveyed; $E$ indicates that the elevation was estimated from topographic maps. 
Table 2. Maximum accumulated freezing degrees days (AFDD) for water years 1950 to 1997.

\begin{tabular}{|c|c|c|c|}
\hline $\begin{array}{l}\text { Water } \\
\text { Year }\end{array}$ & $\begin{array}{l}\text { Date Maximum AFDD } \\
\text { Was Reached }\end{array}$ & $\begin{array}{l}\text { Water Year } \\
\text { Julian Date }\end{array}$ & $\begin{array}{l}\text { Maximum } \\
\text { AFDD }\end{array}$ \\
\hline 1950 & $03 / 13 / 50$ & 164 & 984.4 \\
\hline 1951 & $03 / 03 / 51$ & 154 & 355.6 \\
\hline 1952 & $04 / 01 / 52$ & 184 & 1216.9 \\
\hline 1953 & $03 / 04 / 53$ & 155 & 702.2 \\
\hline 1954 & $01 / 28 / 54$ & 120 & 310.6 \\
\hline 1955 & $03 / 21 / 55$ & 172 & 983.1 \\
\hline 1956 & $03 / 14 / 56$ & 166 & 316.1 \\
\hline 1957 & $02 / 19 / 57$ & 142 & 879.7 \\
\hline 1958 & $02 / 02 / 58$ & 125 & 331.4 \\
\hline 1959 & $02 / 20 / 59$ & 143 & 299.4 \\
\hline 1960 & $03 / 16 / 60$ & 168 & 835.0 \\
\hline 1961 & $02 / 07 / 61$ & 130 & 338.9 \\
\hline 1962 & $03 / 15 / 62$ & 166 & 765.6 \\
\hline 1963 & $01 / 29 / 63$ & 121 & 441.1 \\
\hline 1964 & $03 / 15 / 64$ & 167 & 620.0 \\
\hline 1965 & $03 / 20 / 65$ & 171 & 985.8 \\
\hline 1966 & 03/05/66 & 156 & 632.5 \\
\hline 1967 & $03 / 07 / 67$ & 158 & 924.2 \\
\hline 1968 & $02 / 20 / 68$ & 143 & 955.3 \\
\hline 1969 & $03 / 16 / 69$ & 167 & 705.6 \\
\hline 1970 & $02 / 04 / 70$ & 127 & 433.6 \\
\hline 1971 & $03 / 06 / 71$ & 157 & 452.2 \\
\hline 1972 & $02 / 14 / 72$ & 137 & 553.6 \\
\hline 1973 & $03 / 10 / 73$ & 161 & 1249.7 \\
\hline 1974 & $02 / 28 / 74$ & 151 & 919.2 \\
\hline 1975 & $02 / 25 / 75$ & 148 & 566.4 \\
\hline 1976 & $03 / 12 / 76$ & 164 & 749.4 \\
\hline 1977 & $02 / 09 / 77$ & 132 & 320.0 \\
\hline 1978 & $03 / 04 / 78$ & 155 & 413.9 \\
\hline 1979 & $03 / 14 / 79$ & 165 & 1345.8 \\
\hline 1980 & $02 / 13 / 80$ & 136 & 570.6 \\
\hline 1981 & $02 / 12 / 81$ & 135 & 98.9 \\
\hline 1982 & $02 / 13 / 82$ & 136 & 455.8 \\
\hline 1983 & $02 / 17 / 83$ & 140 & 425.3 \\
\hline
\end{tabular}


Table 2. Continued.

\begin{tabular}{lccc}
\hline $\begin{array}{l}\text { Water } \\
\text { Year }\end{array}$ & $\begin{array}{c}\text { Date Maximum AFDD } \\
\text { Was Reached }\end{array}$ & $\begin{array}{c}\text { Water Year } \\
\text { Julian Date }\end{array}$ & $\begin{array}{c}\text { Maximum } \\
\text { AFDD }\end{array}$ \\
\hline & & & \\
1984 & $03 / 10 / 84$ & 162 & 1198.1 \\
1985 & $03 / 08 / 85$ & 159 & 1011.1 \\
1986 & $02 / 13 / 86$ & 136 & 587.8 \\
1987 & $02 / 28 / 87$ & 151 & 300.8 \\
1988 & $02 / 26 / 88$ & 149 & 740.6 \\
1989 & $03 / 06 / 89$ & 157 & 865.8 \\
1990 & $03 / 02 / 90$ & 153 & 395.6 \\
1991 & $02 / 15 / 91$ & 138 & 813.6 \\
1992 & $02 / 08 / 92$ & 131 & 556.1 \\
1993 & $03 / 13 / 93$ & 164 & 804.4 \\
1994 & $02 / 22 / 94$ & 145 & 383.9 \\
1995 & $01 / 30 / 95$ & 122 & 270.3 \\
1996 & $02 / 12 / 96$ & 135 & 261.9 \\
$1997^{\text {a }}$ & $02 / 28 / 96$ & 151 & 437.2 \\
\hline
\end{tabular}

a Through the end of February 1997 
Table 3. Field survey observations of ice conditions on 18-19 December 1996.

\begin{tabular}{|c|c|c|}
\hline Date & Time & Comments \\
\hline \multirow[t]{4}{*}{18 Dec. 96} & 1515 & $\begin{array}{l}\text { RM 302. Jensen Bridge. Frazil pans in the form of very regular } \\
\text { pancake ice in motion. Some border ice. }\end{array}$ \\
\hline & 1545 & RM 317. Green River Campground. Frazil pans in motion. \\
\hline & 1600 & $\begin{array}{l}\text { RM 316. Immediately downstream of Chew Bridge. Border ice } \\
\text { growth in bend. Restricting progress of frazil pans somewhat. }\end{array}$ \\
\hline & 1645 & $\begin{array}{l}\text { RM 290. Bonanza Bridge. Frazil pans in motion. Some border ice } \\
\text { and large ice islands. }\end{array}$ \\
\hline \multirow[t]{15}{*}{19 Dec. 96} & 0840 & $\begin{array}{l}\text { RM 248. Ouray Bridge. Frazil slush in motion. No frazil pans. } \\
\text { Border ice. }\end{array}$ \\
\hline & 0920 & $\begin{array}{l}\text { RM 249.5. Downstream end of Old Charley Wash. Toe of ice jam in } \\
\text { very sharp bend. Ice cover not consolidated. }\end{array}$ \\
\hline & 1000 & RM 251.8. Ice jam in place. \\
\hline & 1010 & $\begin{array}{l}\text { RM 253.5. Large open lead. Ice arch visible upstream at } \\
\text { approximately RM } 253.8 .100 \% \text { ice coverage upstream of that point. }\end{array}$ \\
\hline & 1015 & RM 254.8. $100 \%$ ice coverage. Juxtaposed pans. \\
\hline & 1025 & $\begin{array}{l}\text { RM 255.6. Boat ramp. Open water lead. } 100 \% \text { ice cover upstream } \\
\text { and downstream. }\end{array}$ \\
\hline & 1035 & $\begin{array}{l}\text { RM 257. Smooth, static ice in slow flowing areas of the river channel. } \\
\text { Frazil pans form ice cover in main channel. }\end{array}$ \\
\hline & 1045 & RM 259. $100 \%$ ice coverage. \\
\hline & 1120 & $\begin{array}{l}\text { RM 262. Open water reach. } 100 \% \text { ice coverage upstream. Some } \\
\text { frazil slush, very little, emerging from downstream end of upstream ice } \\
\text { cover. }\end{array}$ \\
\hline & 1150 & $\begin{array}{l}\text { Overlook directly above RM 262. Stationary ice up to approximately } \\
\text { RM 266. with some open leads. Ice cover formed by juxtaposition of } \\
\text { frazil pans. }\end{array}$ \\
\hline & 1340 & RM 289.8. Bonanza Bridge. Large moving pans. \\
\hline & 1355 & $\begin{array}{l}\text { Overlook at Horseshoe Bend. Ice moving at RM } 276 \text { and upstream of } \\
\text { that point. }\end{array}$ \\
\hline & 1415 & RM 274-275. Large pans moving. \\
\hline & 1520 & $\begin{array}{l}\text { View from RM 268.8-269. Observed the apparent head of jam at } \\
\text { approximately RM } 268 \text {. Moving pans upstream of that point. Water } \\
\text { visible moving up on dry sand bar at RM } 268.8 \text {. Apparent increase in } \\
\text { stage due to ice jam formation downstream. }\end{array}$ \\
\hline & 1635 & RM 302. Jensen Bridge. Frazil pans moving downstream. \\
\hline
\end{tabular}


Table 4. Ice thickness measurements before and after initiation of peaking flows.

\begin{tabular}{|c|c|c|c|c|c|c|c|c|}
\hline \multirow[b]{2}{*}{$\mathbf{R M}$} & \multicolumn{4}{|c|}{ Before Peaking Flows } & \multicolumn{4}{|c|}{ After Peaking Flows } \\
\hline & $\begin{array}{c}\text { Mean } \\
(\mathrm{cm})\end{array}$ & $\begin{array}{c}\text { SD } \\
(\mathrm{cm})\end{array}$ & $\begin{array}{c}\text { Minimum } \\
(\mathrm{cm})\end{array}$ & $\begin{array}{l}\text { Maximum } \\
\text { (cm) }\end{array}$ & $\begin{array}{c}\text { Mean } \\
(\mathrm{cm})\end{array}$ & $\begin{array}{c}\text { SD } \\
(\mathbf{c m})\end{array}$ & $\begin{array}{c}\text { Minimum } \\
(\mathrm{cm})\end{array}$ & $\begin{array}{l}\text { Maximum } \\
\text { (cm) }\end{array}$ \\
\hline 248.4 & 19.5 & 1.6 & 17.7 & 22.9 & 21.4 & 2.4 & 17.7 & 24.7 \\
\hline 249.5 & 20.8 & 3.3 & 17.1 & 26.8 & 21.0 & 2.4 & 17.7 & 24.7 \\
\hline 254.5 & 23.3 & 4.8 & 20.1 & 34.4 & 25.5 & 3.6 & 21.6 & 32.3 \\
\hline 256.8 & 19.4 & 2.2 & 16.5 & 24.1 & 21.0 & 1.7 & 18.3 & 24.1 \\
\hline 258.3 & 21.7 & 3.6 & 16.5 & 29.3 & 23.4 & 2.7 & 19.8 & 29.3 \\
\hline 262.0 & 19.8 & 2.8 & 15.2 & 22.3 & 21.3 & 1.5 & 19.8 & 23.5 \\
\hline 265.4 & 19.9 & 1.8 & 17.7 & 22.9 & 20.1 & 3.9 & 12.8 & 24.1 \\
\hline 276.5 & 20.6 & 7.3 & 14.0 & 43.3 & 19.1 & 3.4 & 14.6 & 25.3 \\
\hline 278.0 & 20.9 & 4.5 & 15.2 & 30.5 & 21.5 & 1.7 & 19.8 & 23.5 \\
\hline 279.0 & 20.6 & 3.9 & 13.4 & 24.1 & 21.1 & 3.7 & 14.6 & 24.7 \\
\hline 290.4 & 18.4 & 4.8 & 9.4 & 23.5 & 18.7 & 6.1 & 10.7 & 26.8 \\
\hline 294.0 & 19.7 & 2.8 & 17.1 & 25.3 & 22.9 & 2.6 & 19.2 & 27.4 \\
\hline 301.3 & 19.9 & 1.2 & 17.7 & 21.6 & 23.5 & 2.5 & 21.0 & 27.4 \\
\hline 302.2 & 21.5 & 2.2 & 17.7 & 24.1 & 21.0 & 3.7 & 15.2 & 25.3 \\
\hline 307.0 & 29.8 & 19.2 & 11.3 & 68.6 & $-^{\mathrm{a}}$ & - & - & - \\
\hline 308.2 & 24.8 & 26.9 & 12.8 & 109.1 & - & - & - & - \\
\hline 316.3 & 24.4 & 12.2 & 16.5 & 45.7 & - & - & - & - \\
\hline
\end{tabular}

${ }^{a}$ No ice was present. 
Table 5. Results of two-way analysis of variance (ANOVA) to evaluate the effects of cross section location (river mile, $R M$ ) and fluctuation regime (steady flow vs. fluctuating flow) on ice cover thickness.

\begin{tabular}{lcccc}
\hline $\begin{array}{l}\text { Source of } \\
\text { Variation }\end{array}$ & $\begin{array}{c}\text { Degrees of } \\
\text { Freedom }\end{array}$ & Mean Square & $\boldsymbol{F}$-Value & $\boldsymbol{P}$ \\
\hline RM & 1.00 & 14.49 & 1.01 & 0.317 \\
Regime $^{\mathrm{a}}$ & 1.00 & 0.12 & 0.01 & 0.942 \\
\hline
\end{tabular}

${ }^{a}$ Repeated measures analysis calculated using the type III mean square of the measurements of ice thickness within each cross section as the error term. 
Table 6. Stage, velocity, depth and Froude number for a steady flow of $2400 \mathrm{cfs}$.

\begin{tabular}{lccccc}
\hline Location & $\begin{array}{c}\text { River } \\
\text { Mile }\end{array}$ & $\begin{array}{c}\text { Stage } \\
\text { (ft MSL) }\end{array}$ & $\begin{array}{c}\text { Velocity } \\
\text { (ft/s) }\end{array}$ & $\begin{array}{c}\text { Average } \\
\text { Depth } \\
\text { (ft) }\end{array}$ & $\begin{array}{c}\text { Froude } \\
\text { Number }\end{array}$ \\
\hline Jensen Gage & 316.6 & 4762.50 & 1.20 & 2.98 & 0.123 \\
Razor Island & 311.5 & 4741.79 & 1.66 & 2.54 & 0.184 \\
Dinosaur Bend & 307.1 & 4731.00 & 2.17 & 2.95 & 0.223 \\
Jensen Bridge & 302.3 & 4723.20 & 0.59 & 7.18 & 0.039 \\
Walker Hollow & 294.0 & 4709.75 & 1.55 & 3.43 & 0.147 \\
Bonanza Bridge & 290.4 & 4704.23 & 1.25 & 4.10 & 0.109 \\
Horseshoe Bend & 279.0 & 4692.04 & 1.00 & 7.29 & 0.065 \\
Brennan Bottom & 265.4 & 4671.44 & 1.30 & 2.65 & 0.141 \\
Leota Bottom & 258.0 & 4661.76 & 0.94 & 4.84 & 0.075 \\
Ouray Refuge & 254.6 & 4658.19 & 1.03 & 5.02 & 0.081 \\
Ouray Bridge & 248.0 & 4648.69 & 1.07 & 6.12 & 0.076 \\
\hline
\end{tabular}


Table 7. Stage, velocity, depth, and Froude number at first peak following the steady flow period.

\begin{tabular}{|c|c|c|c|c|c|c|}
\hline Location & $\begin{array}{c}\text { River } \\
\text { Mile }\end{array}$ & $\begin{array}{c}\text { Time } \\
\text { (day \& hour) }\end{array}$ & $\begin{array}{c}\text { Stage } \\
\text { (ft MSL) }\end{array}$ & $\begin{array}{c}\text { Velocity } \\
\text { (ft/s) }\end{array}$ & $\begin{array}{c}\text { Average } \\
\text { Depth } \\
\text { (ft) }\end{array}$ & $\begin{array}{l}\text { Froude } \\
\text { Number }\end{array}$ \\
\hline Jensen Gage & 316.6 & $1 / 262000$ & 4762.69 & 1.22 & 3.17 & 0.121 \\
\hline Razor Island & 311.5 & $1 / 262200$ & 4741.98 & 1.69 & 2.73 & 0.180 \\
\hline Dinosaur Bend & 307.1 & $1 / 270000$ & 4731.57 & 2.09 & 3.52 & 0.196 \\
\hline Jensen Bridge & 302.3 & $1 / 270900$ & 4723.78 & 0.58 & 7.76 & 0.037 \\
\hline Walker Hollow & 294.0 & $1 / 27 \quad 1200$ & 4709.92 & 1.58 & 3.60 & 0.147 \\
\hline Bonanza Bridge & 290.4 & $1 / 271400$ & 4704.53 & 1.22 & 4.40 & 0.102 \\
\hline Horseshoe Bend & 279.0 & $1 / 271700$ & 4692.41 & 1.02 & 7.66 & 0.065 \\
\hline Brennan Bottom & 265.4 & $1 / 28 \quad 0200$ & 4671.53 & 1.32 & 2.74 & 0.141 \\
\hline Leota Bottom & 258.0 & $1 / 28 \quad 0500$ & 4661.84 & 0.97 & 4.92 & 0.077 \\
\hline Ouray Refuge & 254.6 & $1 / 28 \quad 0800$ & 4658.35 & 1.04 & 5.18 & 0.081 \\
\hline Ouray Bridge & 248.0 & $1 / 28 \quad 1400$ & 4648.82 & 1.08 & 6.25 & 0.076 \\
\hline
\end{tabular}


Table 8. Stage, velocity, depth, and Froude number at first trough following initial peak.

\begin{tabular}{|c|c|c|c|c|c|c|}
\hline Location & $\begin{array}{c}\text { River } \\
\text { Mile }\end{array}$ & $\begin{array}{c}\text { Time } \\
\text { (day \& hour) }\end{array}$ & $\begin{array}{c}\text { Stage } \\
\text { (ft MSL) }\end{array}$ & $\begin{array}{c}\text { Velocity } \\
(\mathrm{ft} / \mathrm{s})\end{array}$ & $\begin{array}{c}\text { Average } \\
\text { Depth } \\
\text { (ft) }\end{array}$ & $\begin{array}{c}\text { Froude } \\
\text { Number }\end{array}$ \\
\hline Jensen Gage & 316.6 & $1 / 270900$ & 4762.06 & 1.16 & 2.54 & 0.128 \\
\hline Razor Island & 311.5 & $1 / 27 \quad 1100$ & 4741.39 & 1.57 & 2.14 & 0.189 \\
\hline Dinosaur Bend & 307.1 & $1 / 270900$ & 4730.04 & 2.00 & 1.99 & 0.250 \\
\hline Jensen Bridge & 302.3 & $1 / 27 \quad 1800$ & 4722.92 & 0.59 & 6.90 & 0.040 \\
\hline Walker Hollow & 294.0 & $1 / 272200$ & 4709.69 & 1.55 & 3.37 & 0.149 \\
\hline Bonanza Bridge & 290.4 & $1 / 280000$ & 4704.15 & 1.24 & 4.02 & 0.109 \\
\hline Horseshoe Bend & 279.0 & $1 / 28 \quad 0500$ & 4691.99 & 1.01 & 7.24 & 0.066 \\
\hline Brennan & 265.4 & $1 / 28 \quad 1500$ & 4671.43 & 1.30 & 2.64 & 0.141 \\
\hline \multicolumn{7}{|l|}{ Bottom } \\
\hline Leota Bottom & 258.0 & $1 / 28 \quad 2200$ & 4661.76 & 0.95 & 4.84 & 0.076 \\
\hline Ouray Refuge & 254.6 & - & -- & -- & - & -- \\
\hline Ouray Bridge & 248.0 & - & - & -- & - & -- \\
\hline
\end{tabular}


Table 9. Stage, velocity, depth and Froude number at lowest trough.

\begin{tabular}{lccccccc}
\hline & \multicolumn{1}{c}{ River } & $\begin{array}{c}\text { Time } \\
\text { Location }\end{array}$ & $\begin{array}{c}\text { Stage } \\
\text { (day \& hour) }\end{array}$ & $\begin{array}{c}\text { Velocity } \\
\text { (ft MSL) }\end{array}$ & $\begin{array}{c}\text { Average } \\
\text { (ft/s) }\end{array}$ & $\begin{array}{c}\text { Depth } \\
\text { (ft) }\end{array}$ & $\begin{array}{c}\text { Froude } \\
\text { Number }\end{array}$ \\
\hline Jensen Gage & 316.6 & $1 / 28$ & 0700 & 4761.74 & 1.12 & 2.22 & 0.132 \\
Razor Island & 311.5 & $1 / 28$ & 0900 & 4741.07 & 1.49 & 1.82 & 0.195 \\
Dinosaur Bend & 307.1 & $1 / 28$ & 1300 & 4730.1 & 2.14 & 2.05 & 0.263 \\
Jensen Bridge & 302.3 & $1 / 28$ & 1400 & 4722.07 & 0.60 & 6.05 & 0.043 \\
Walker Hollow & 294.0 & $1 / 28$ & 1600 & 4709.46 & 1.50 & 3.14 & 0.149 \\
Bonanza Bridge & 290.4 & $1 / 28$ & 1900 & 4703.82 & 1.24 & 3.69 & 0.114 \\
Horseshoe Bend & 279.0 & $1 / 28$ & 2200 & 4691.64 & 0.98 & 6.89 & 0.066 \\
Brennan Bottom & 265.4 & $1 / 29$ & 0700 & 4671.33 & 1.29 & 2.54 & 0.143 \\
Leota Bottom & 258.0 & $1 / 29$ & 1200 & 4661.66 & 0.92 & 4.74 & 0.074 \\
Ouray Refuge & 254.6 & $1 / 29$ & 1500 & 4657.98 & 1.04 & 4.81 & 0.084 \\
Ouray Bridge & 248.0 & $1 / 29$ & 2100 & 4648.6 & 1.05 & 6.03 & 0.075 \\
\hline
\end{tabular}


Table 10. Stage, velocity, depth and Froude number at highest peak.

\begin{tabular}{|c|c|c|c|c|c|c|}
\hline Location & $\begin{array}{l}\text { River } \\
\text { Mile } \\
\end{array}$ & $\begin{array}{c}\text { Time } \\
\text { (day \& hour) } \\
\end{array}$ & $\begin{array}{c}\begin{array}{c}\text { Stage } \\
\text { (ft MSL) }\end{array} \\
\end{array}$ & $\begin{array}{c}\text { Velocity } \\
(\mathrm{ft} / \mathrm{s})\end{array}$ & $\begin{array}{c}\text { Average } \\
\text { Depth } \\
\text { (ft) }\end{array}$ & $\begin{array}{c}\text { Froude } \\
\text { Number }\end{array}$ \\
\hline Jensen Gage & 316.6 & $1 / 29 \quad 1700$ & 4763.33 & 1.27 & 3.81 & 0.115 \\
\hline Razor Island & 311.5 & $1 / 291900$ & 4742.59 & 1.73 & 3.34 & 0.167 \\
\hline Dinosaur Bend & 307.1 & $1 / 292100$ & 4732.23 & 2.38 & 4.18 & 0.205 \\
\hline Jensen Bridge & 302.3 & -- & - & - & -- & -- \\
\hline Walker Hollow & 294.0 & -- & -- & -- & -- & - \\
\hline Bonanza Bridge & 290.4 & -- & - & -- & -- & -- \\
\hline Horseshoe Bend & 279.0 & - & -- & -- & -- & -- \\
\hline Brennan Bottom & 265.4 & -- & - & - & -- & -- \\
\hline Leota Bottom & 258.0 & - & - & - & -- & -- \\
\hline Ouray Refuge & 254.6 & - & - & -- & - & -- \\
\hline Ouray Bridge & 248.0 & -- & -- & -- & -- & - \\
\hline
\end{tabular}


Table 11. Maximum AFDD, mean daily winter flow, maximum reported upstream ice cover extent, and the daily release schedule during ice observations in the study area.

\begin{tabular}{ccccc}
\hline Winter & $\begin{array}{c}\text { Maximum } \\
\text { AFDD }\end{array}$ & $\begin{array}{c}\text { Mean Daily } \\
\text { Winter Flowa } \\
\text { (cfs) }\end{array}$ & $\begin{array}{c}\text { Upstream } \\
\text { Extent of } \\
\text { Ice Cover } \\
\text { (RM) }\end{array}$ & $\begin{array}{c}\text { Daily Release } \\
\text { Schedule from } \\
\text { Flaming Gorge Dam }\end{array}$ \\
\hline $1986-87$ & 301 & 4,234 & 302 & Fluctuating \\
$1987-88$ & 741 & 2,701 & 316 & Fluctuating \\
$1993-94$ & 384 & 2,676 & 302 & Fluctuating \\
$1994-95$ & 270 & 1,650 & 310 & Steady \\
$1996-97$ & 437 & 2,440 & 310.8 & Steady \\
\hline
\end{tabular}

${ }^{a}$ Flow reported at the Jensen gage for November through February. 
FIGURES 


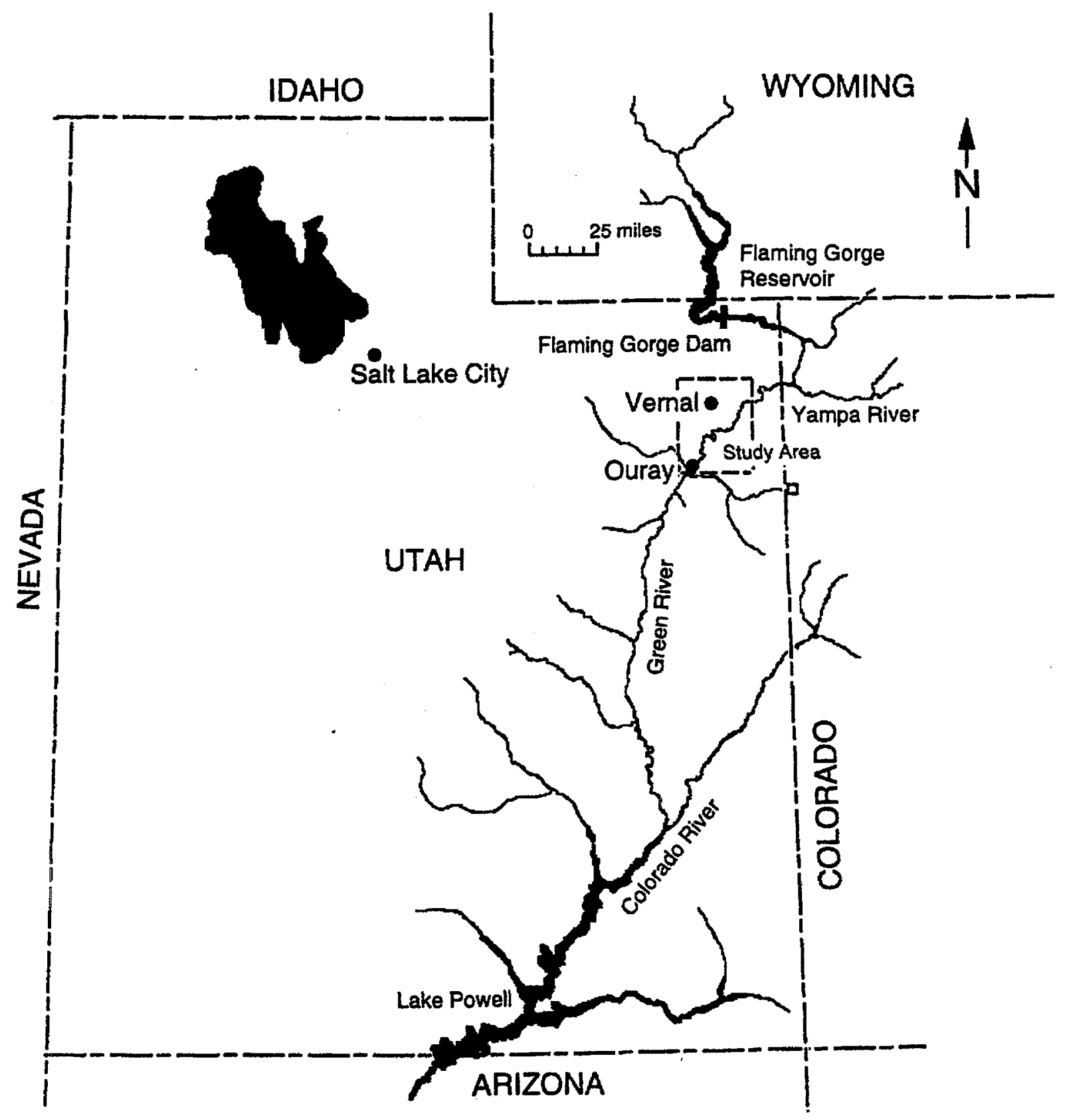

Figure 1. Map of the Green River basin 


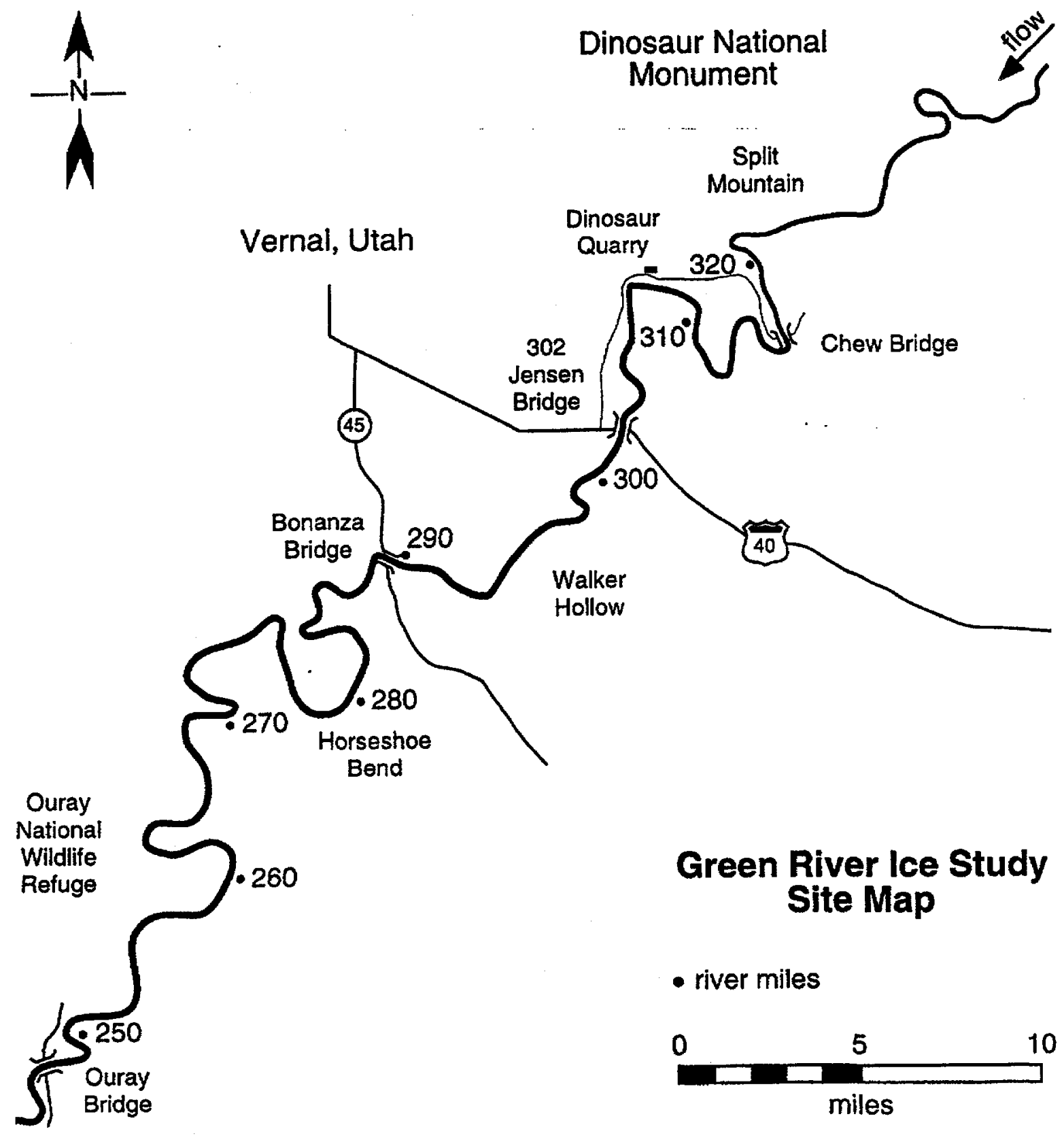

Figure 2. Map of the study area in the Green River 


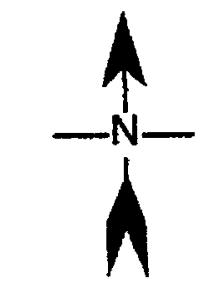

Dinosaur National

Monument

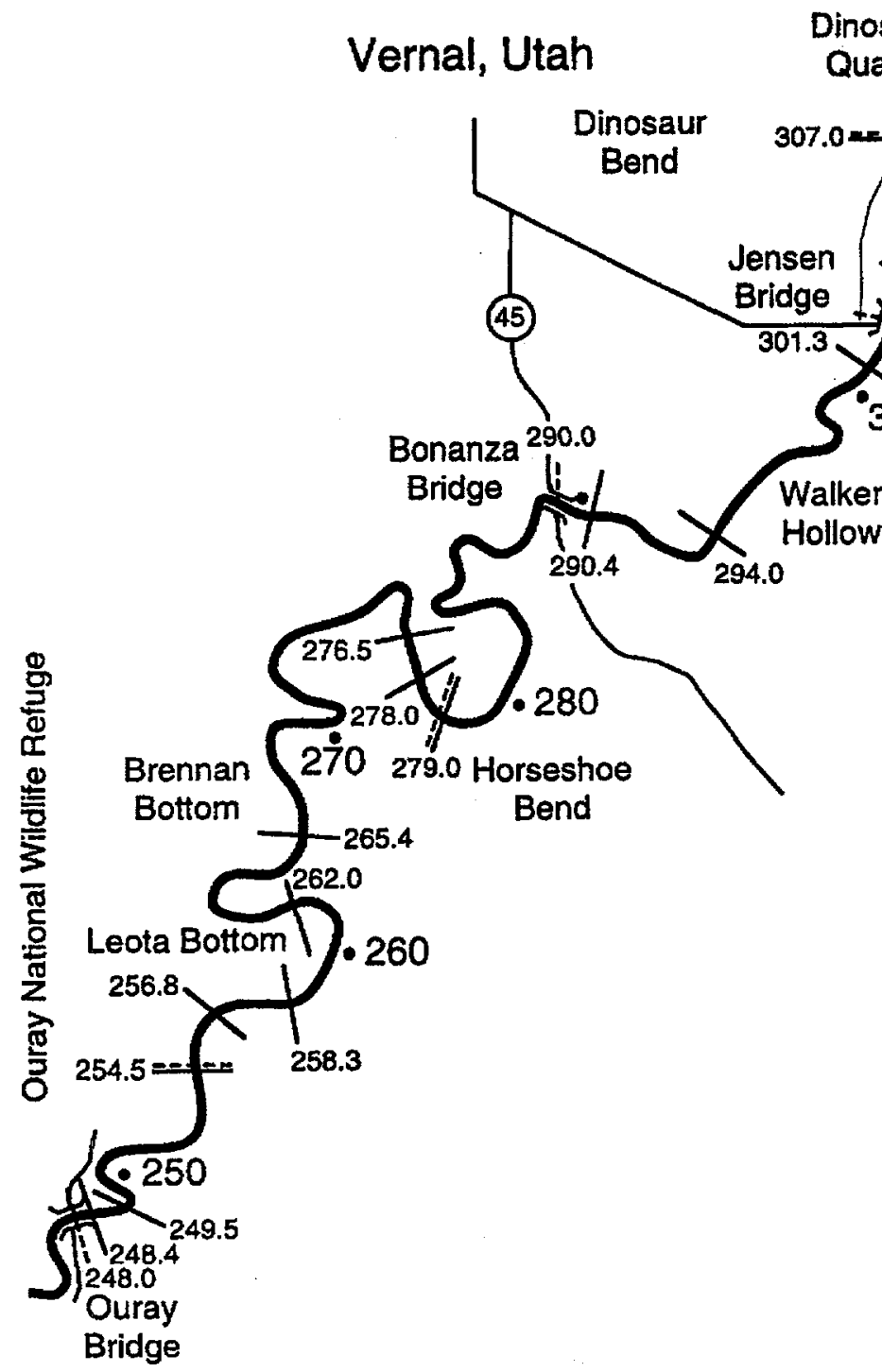

\section{Green River Ice Study Site Map}

Ice Thickness Measurement Location ....- Stage Measurement Location

- River Miles

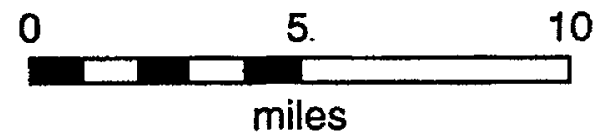

Figure 3. Locations of cross sections for stage change and ice thickness measurements 


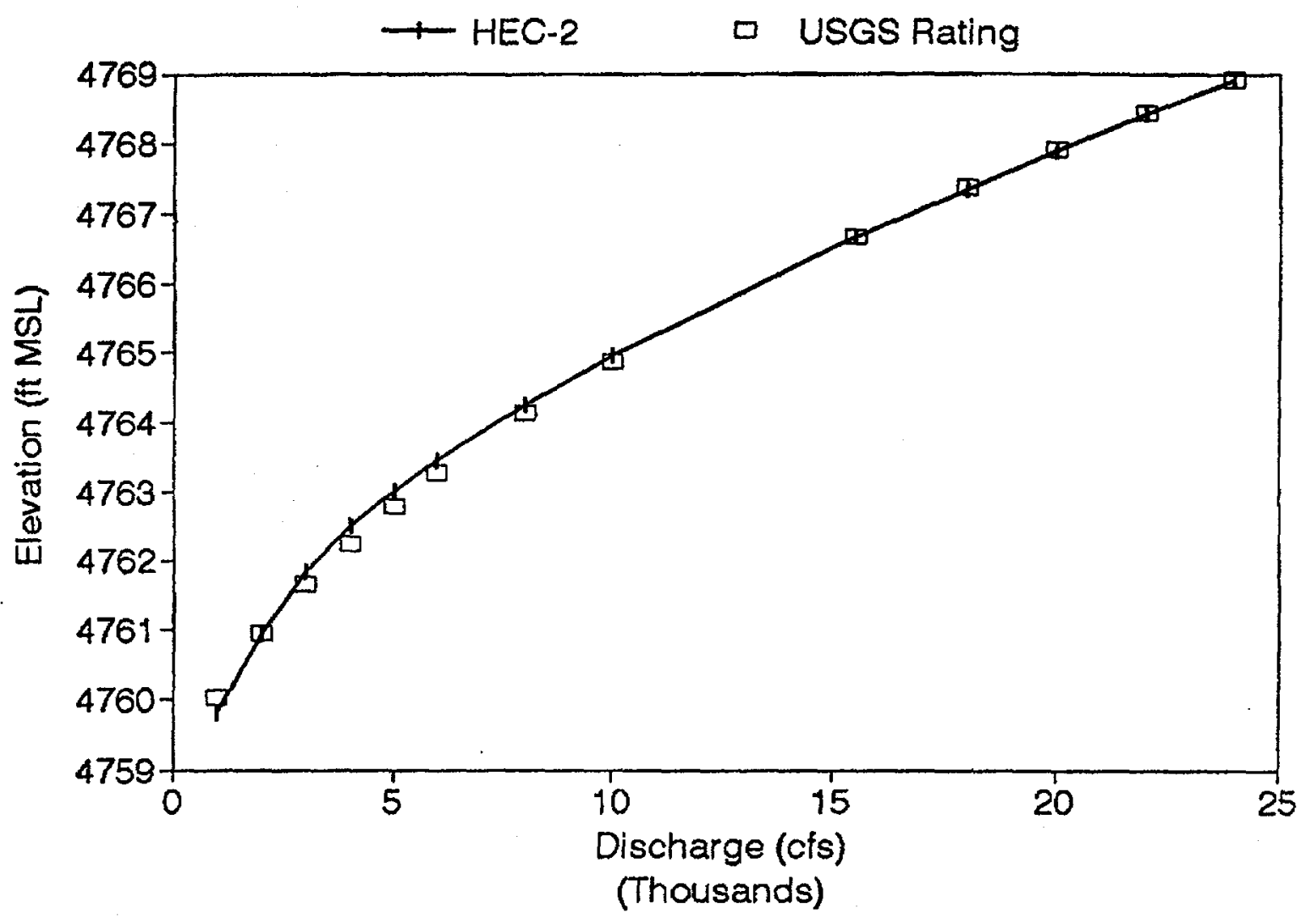

Figure 4. Stage-discharge curve for the Jensen, Utah gage 


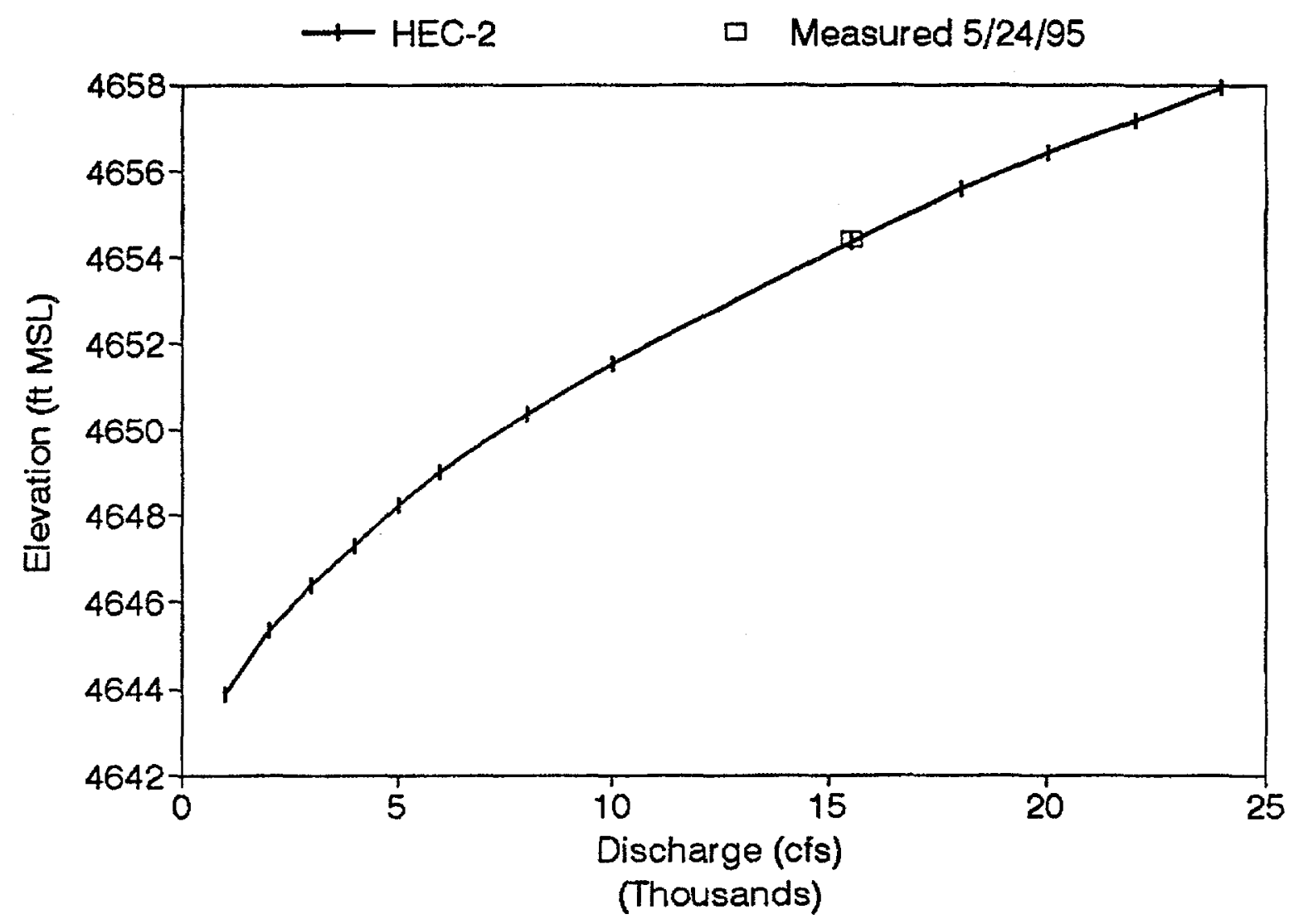

Figure 5. Stage-discharge curve for the Ouray, Utah bridge 


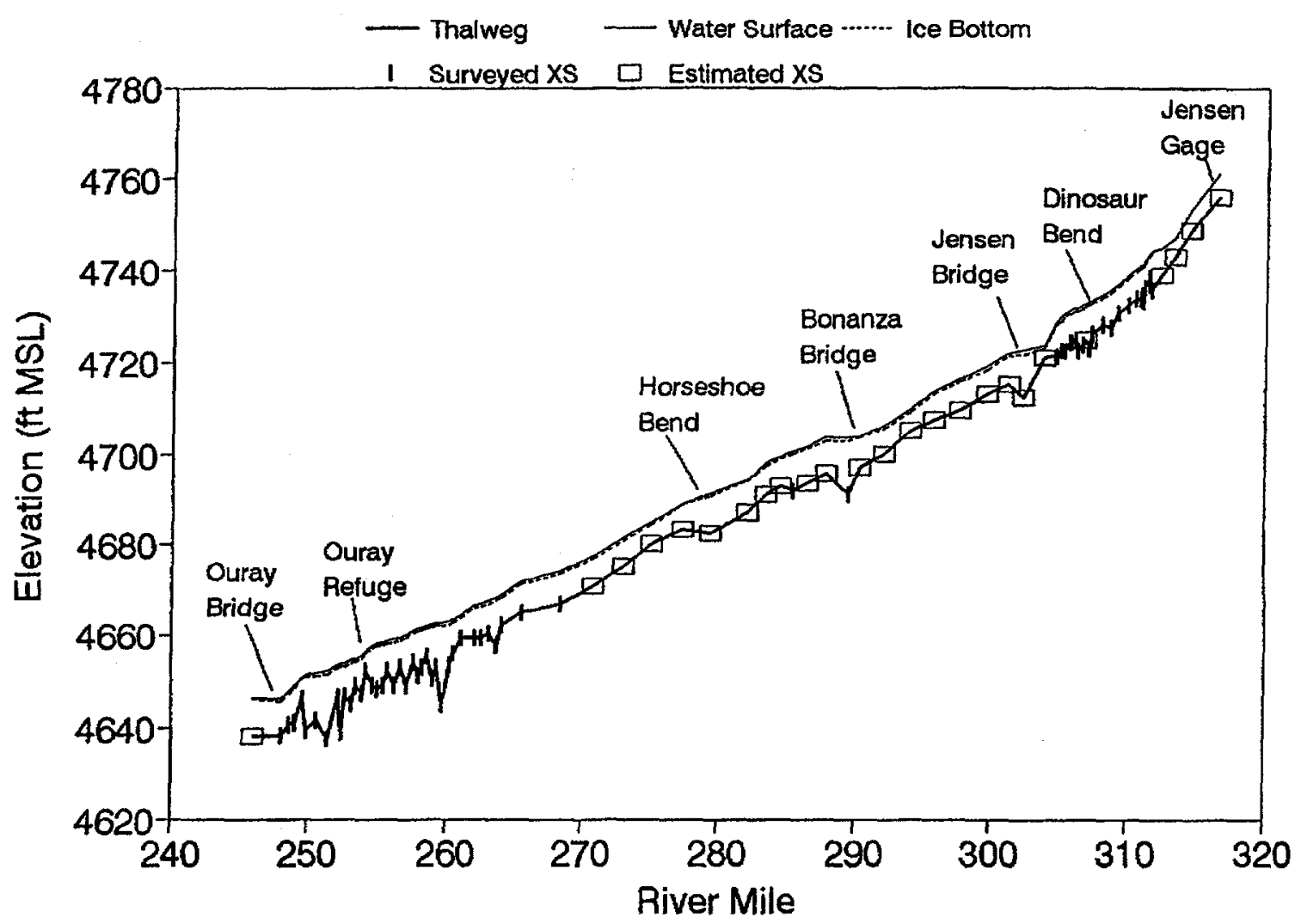

Figure 6. Graphical representation of cross section locations and types 


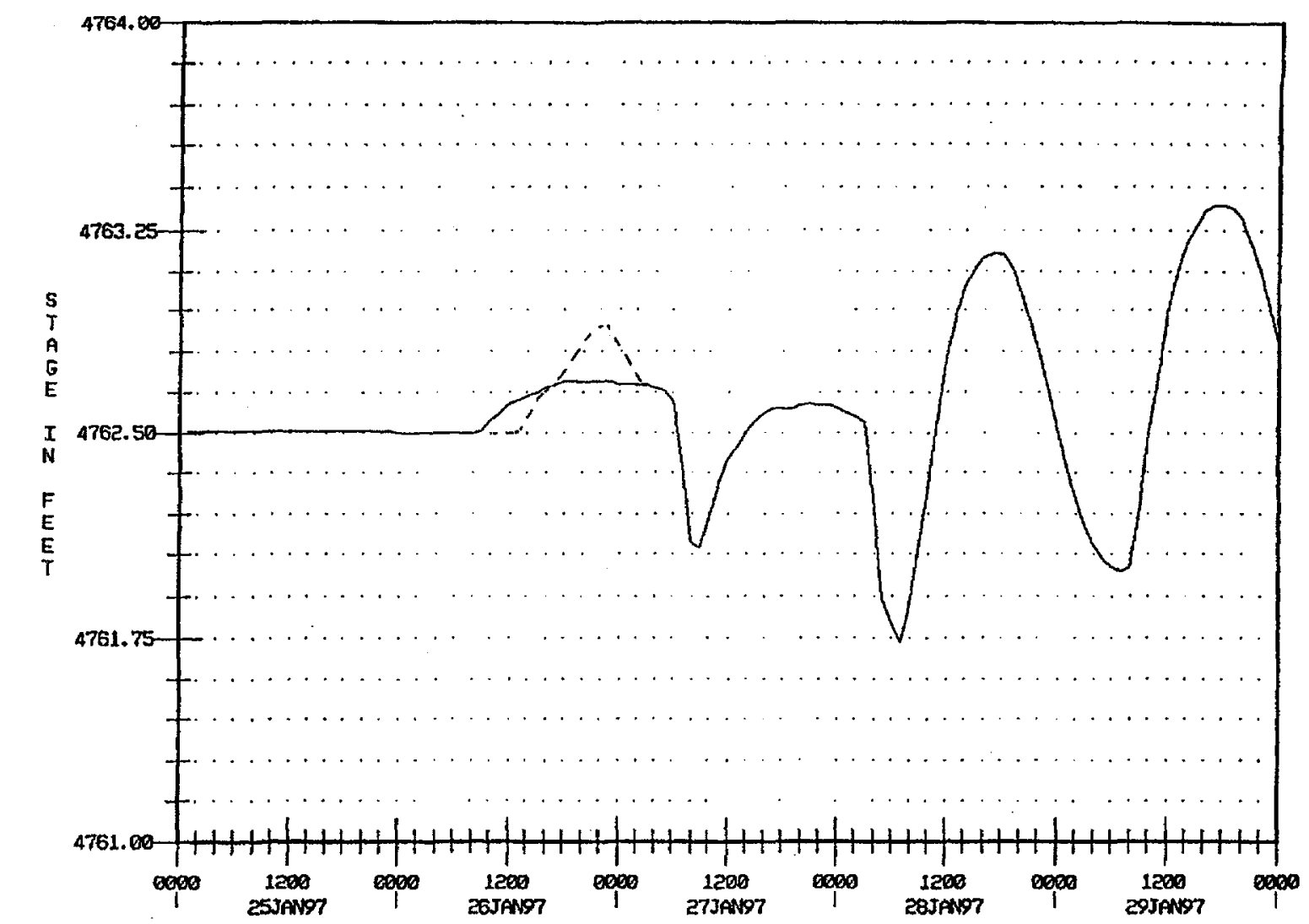

Reported Stage at Jensen Gage

Measured Stage at Chew Bridge

Figure 7. Measured stage at the Chew Bridge (RM 316) and reported stage from the Jensen gage (RM 316.6) 


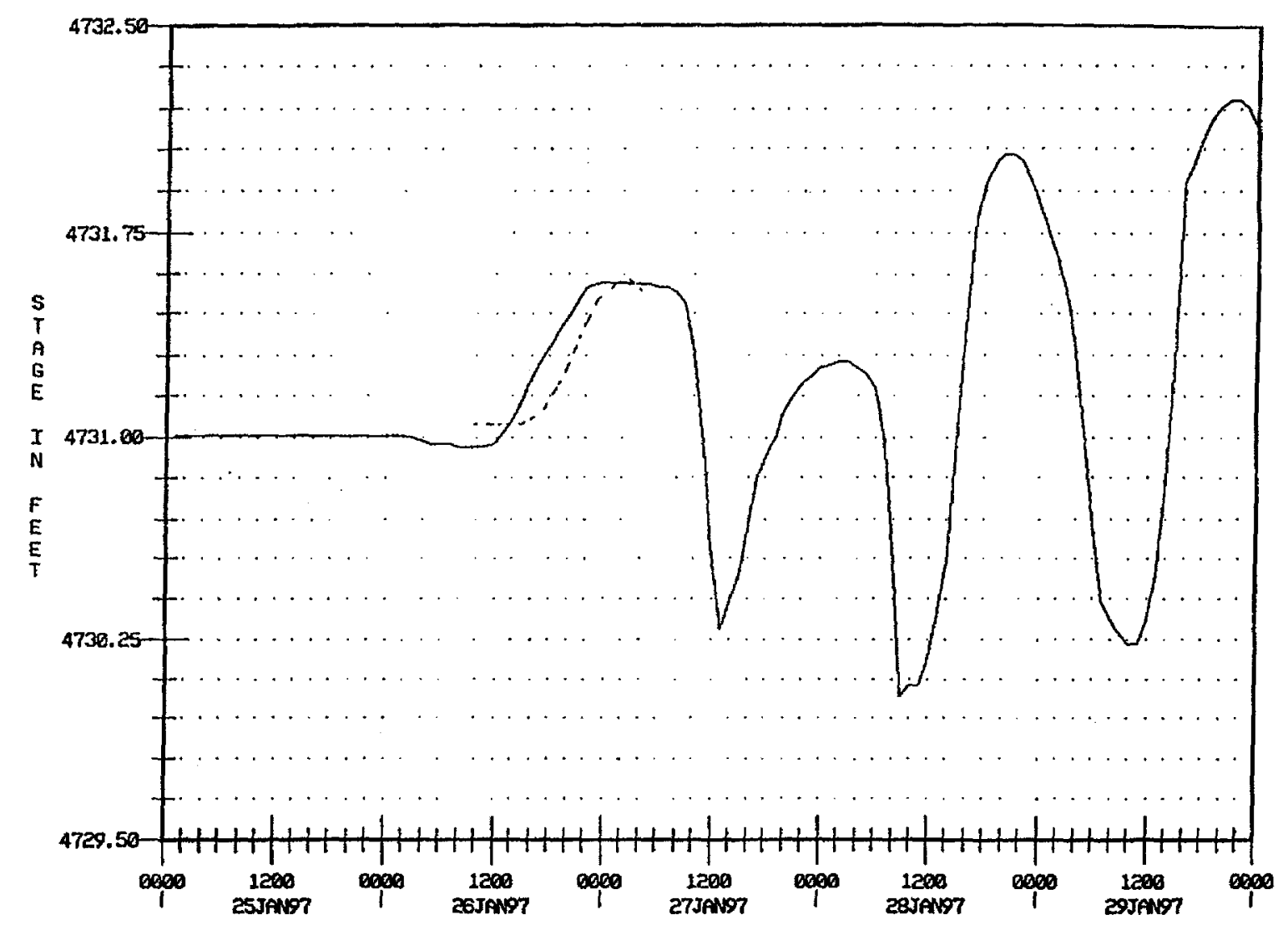

Simulated Stage at Dinosaur Bend

Measured Stage at Dinosaur Bend

Figure 8. Simulated and measured hydrograph at Dinosaur Bend (RM 307) 


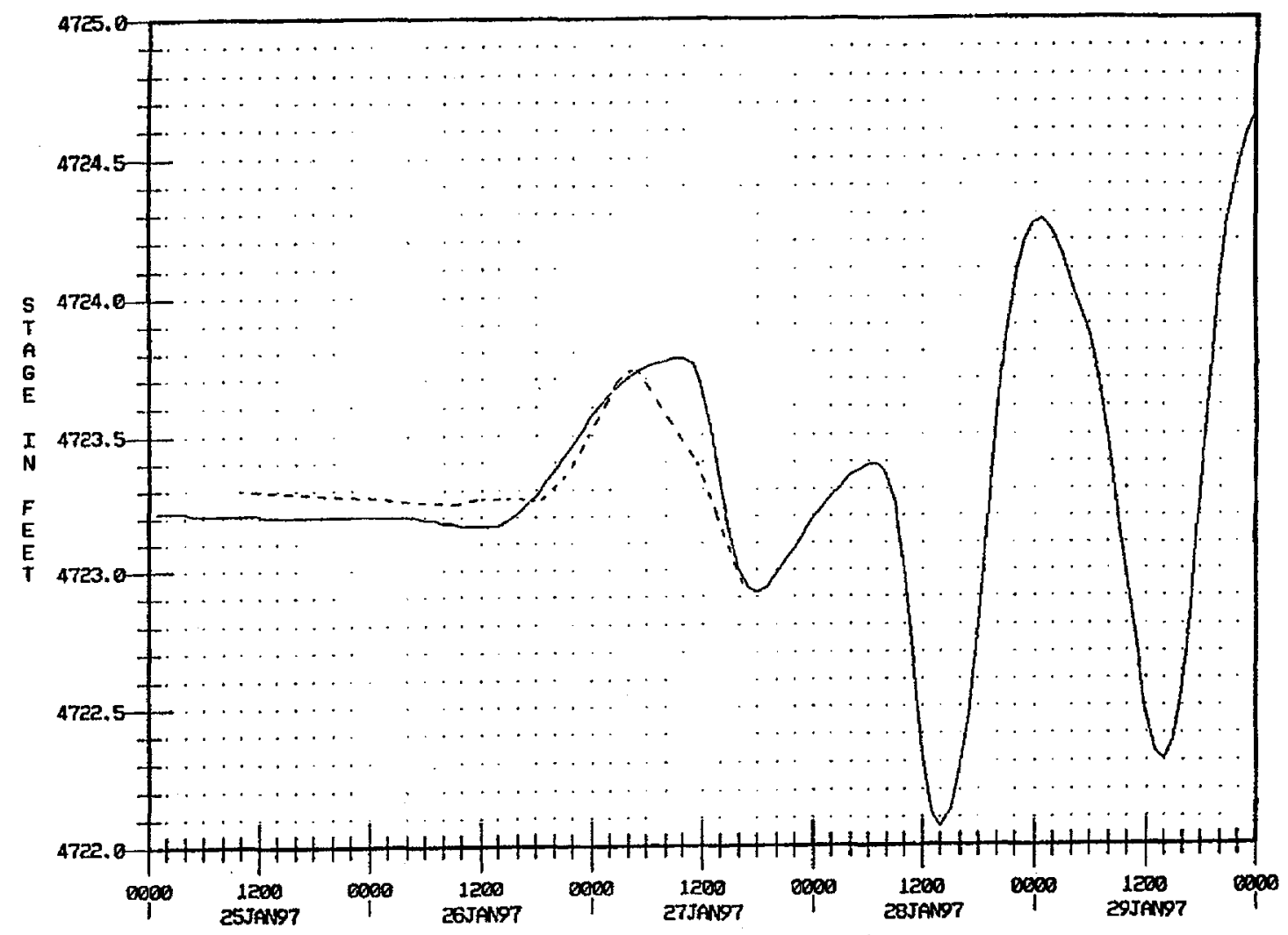

Jensen Bridge Simulated Stage Jensen Bridge Measured Stage

Figure 9. Simulated and measured stage for the Jensen Bridge (302.3) 


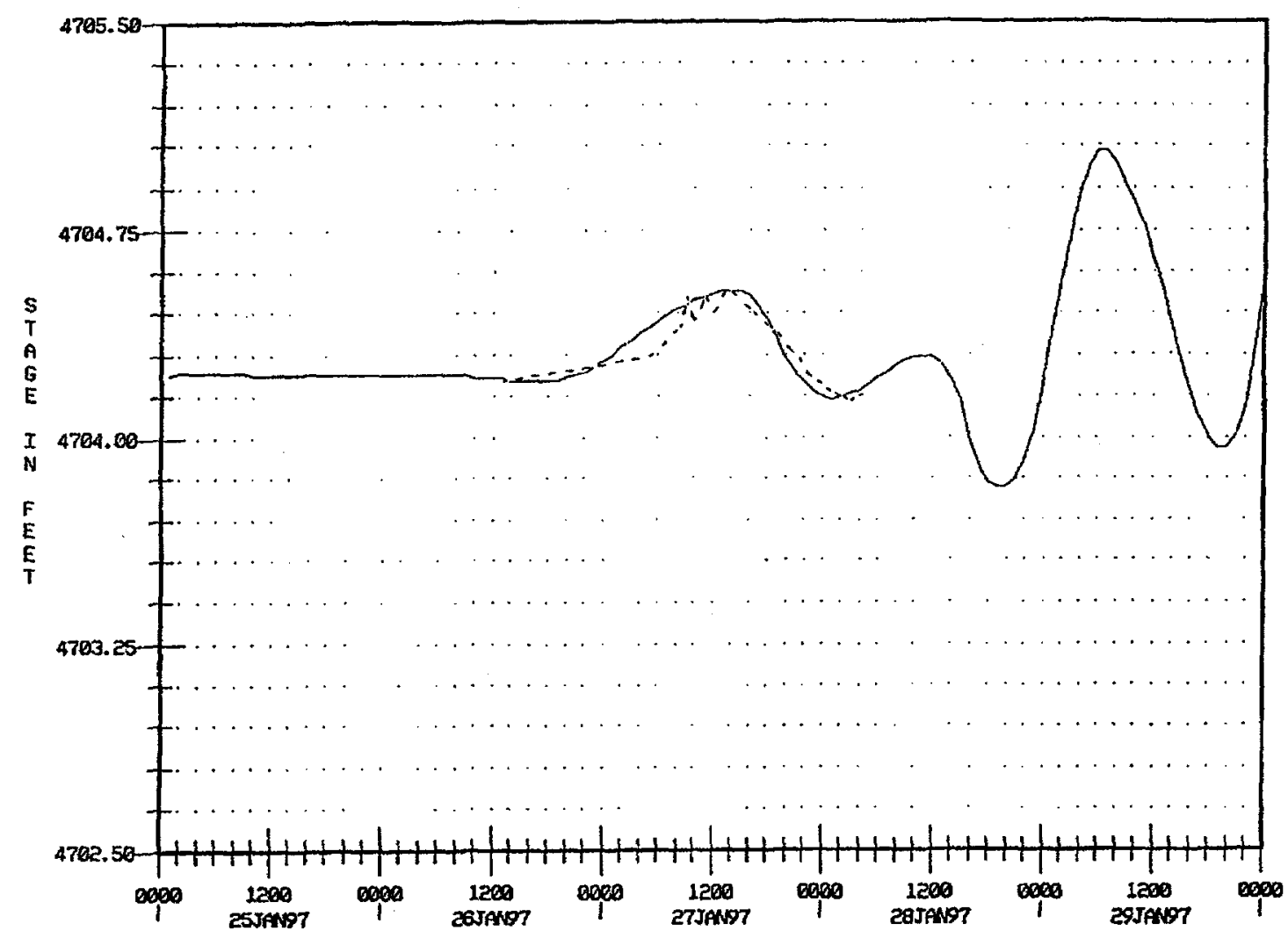

Simulated Stage at Bonanza Bridge

Measured Stage at Bonanza Bridge

Figure 10. Simulated and measured stage at Bonanza Bridge (RM 290.4) 


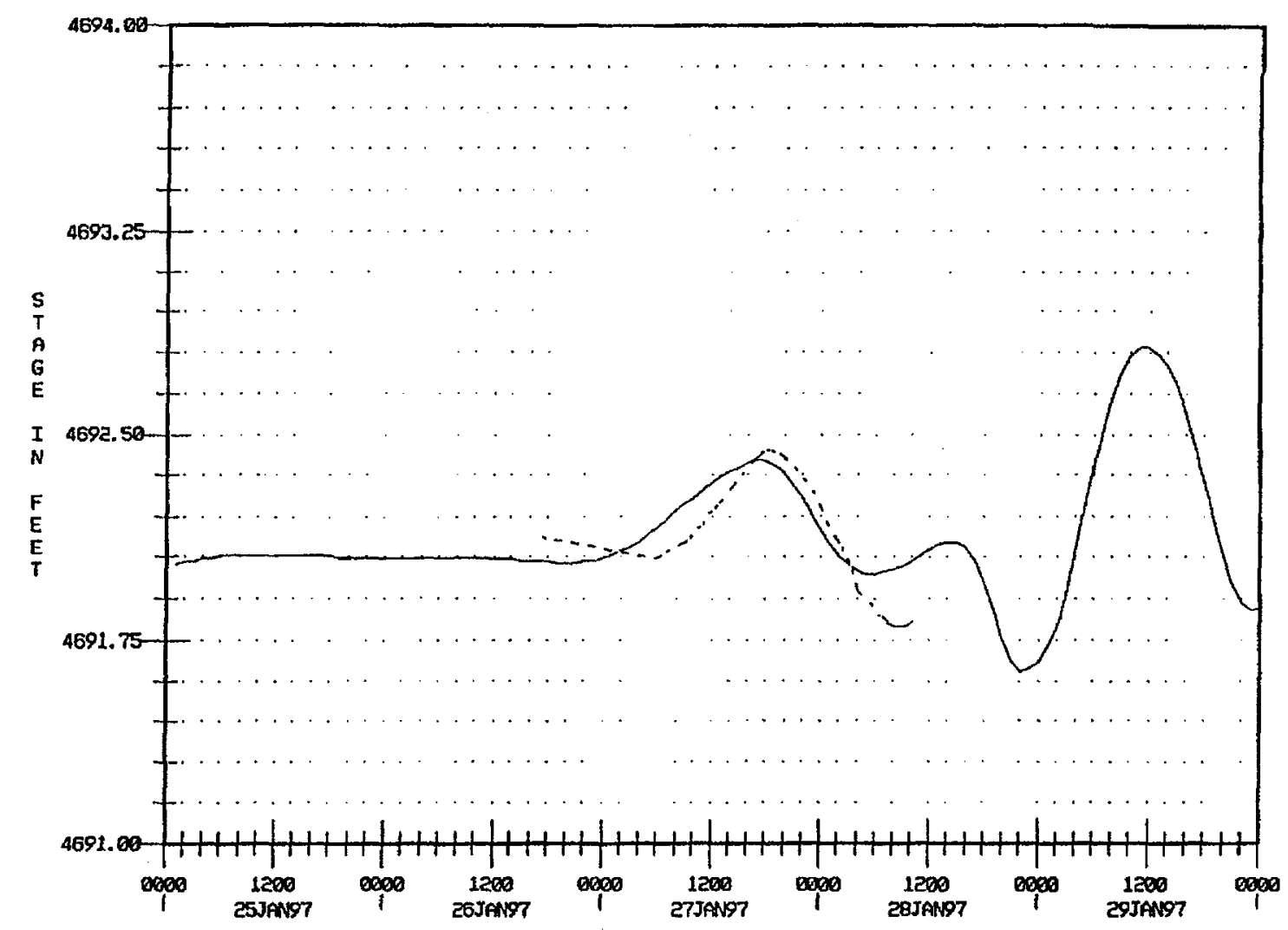

- Simulated Slage at Horseshoe Bend Measured Stage at Horseshoe Bend

Figure 11. Simulated and measured stage at Horseshoe Bend (RM 279.0) 


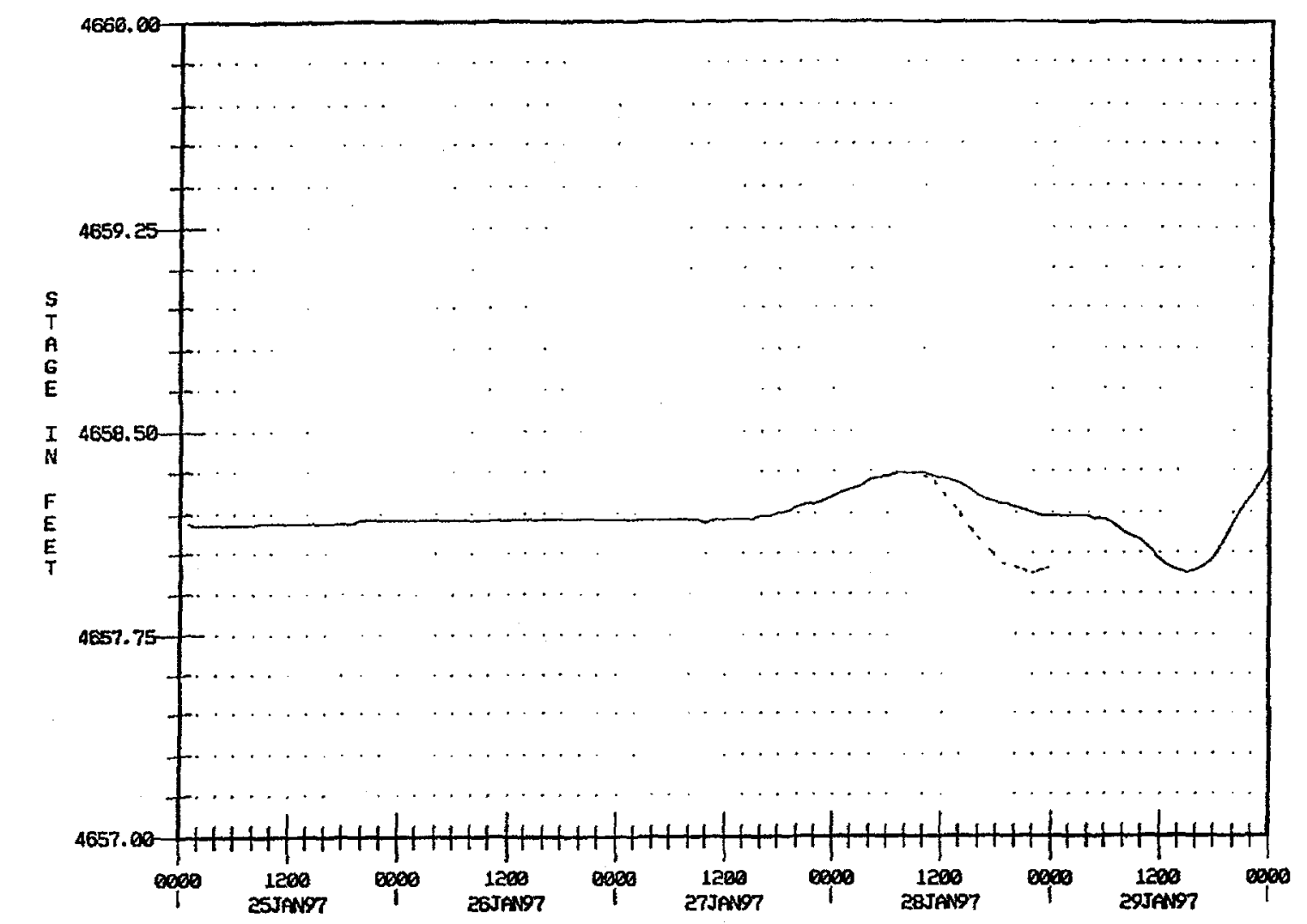

Simulated Stage at the Ouray Retuge

Measured Stage at the Ouray Refuge

Figure 12. Simulated and measured stage at the Ouray National Wildlife Refuge (RM 254.6) 


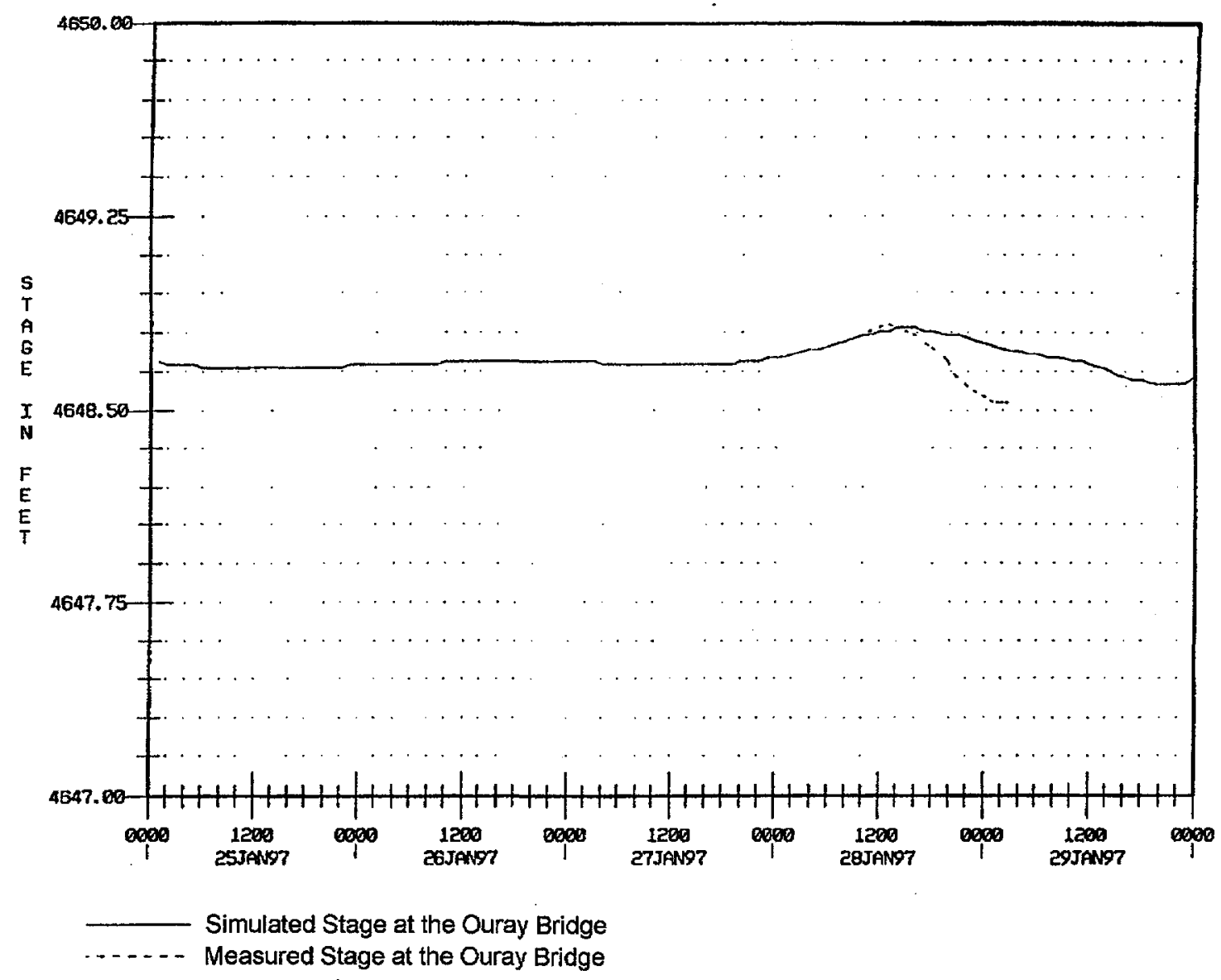

Figure 13. Simulated and measured stage at the Ouray Bridge (RM 248.0) 


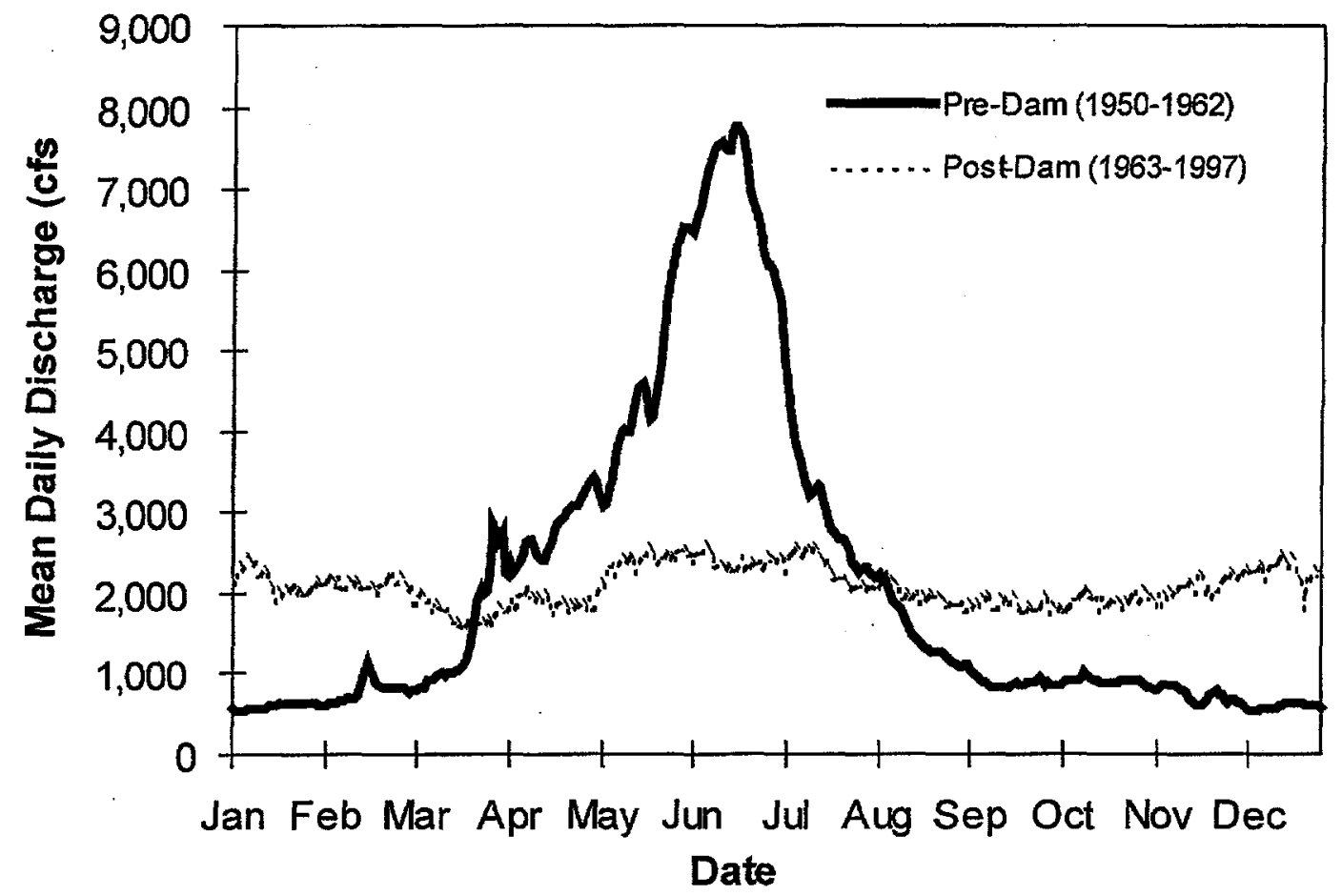

Figure 14. Mean daily discharge at the Greendale Gage for pre-dam and post-dam periods 


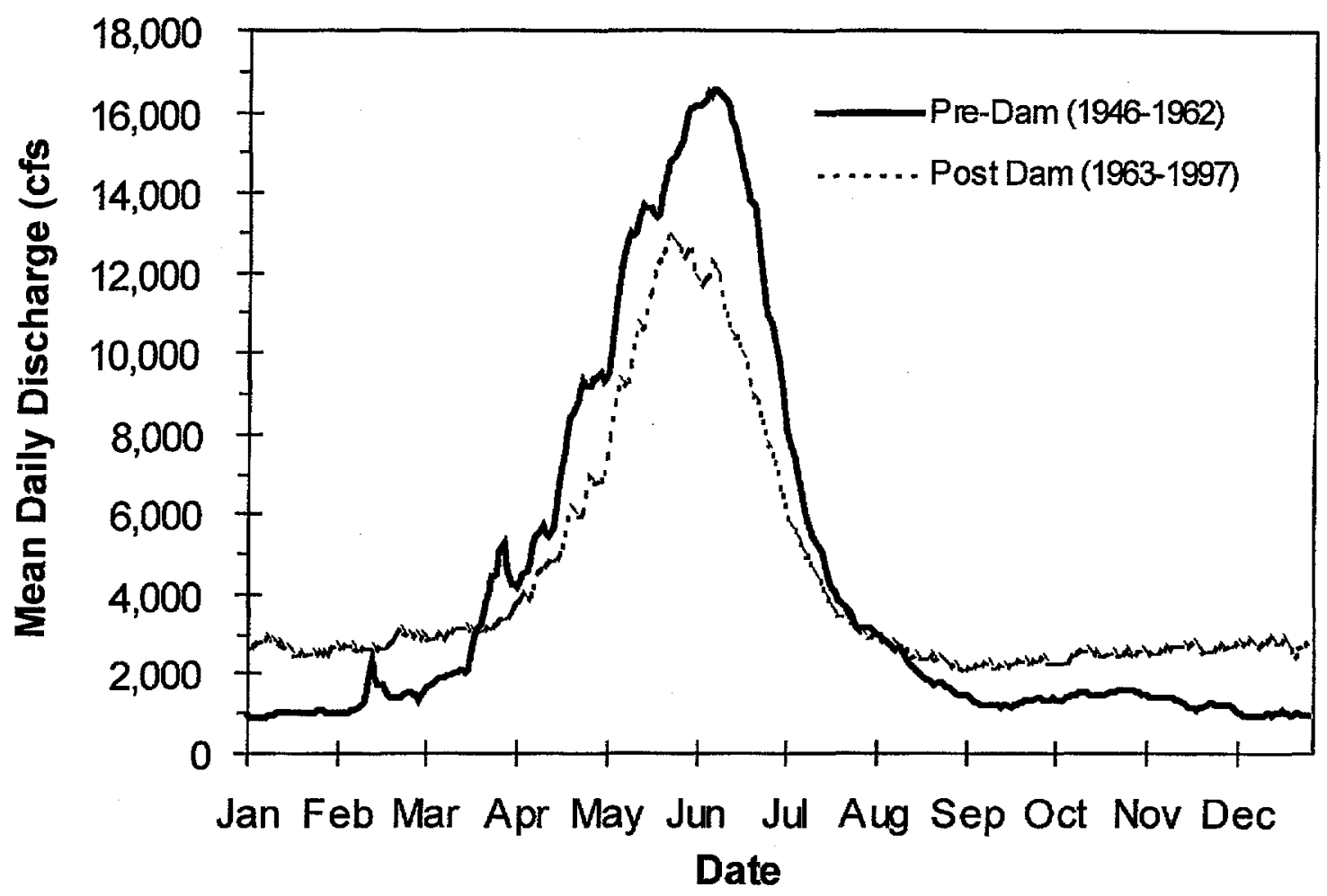

Figure 15. Mean daily discharge at the Jensen gage for pre-dam and post-dam periods 


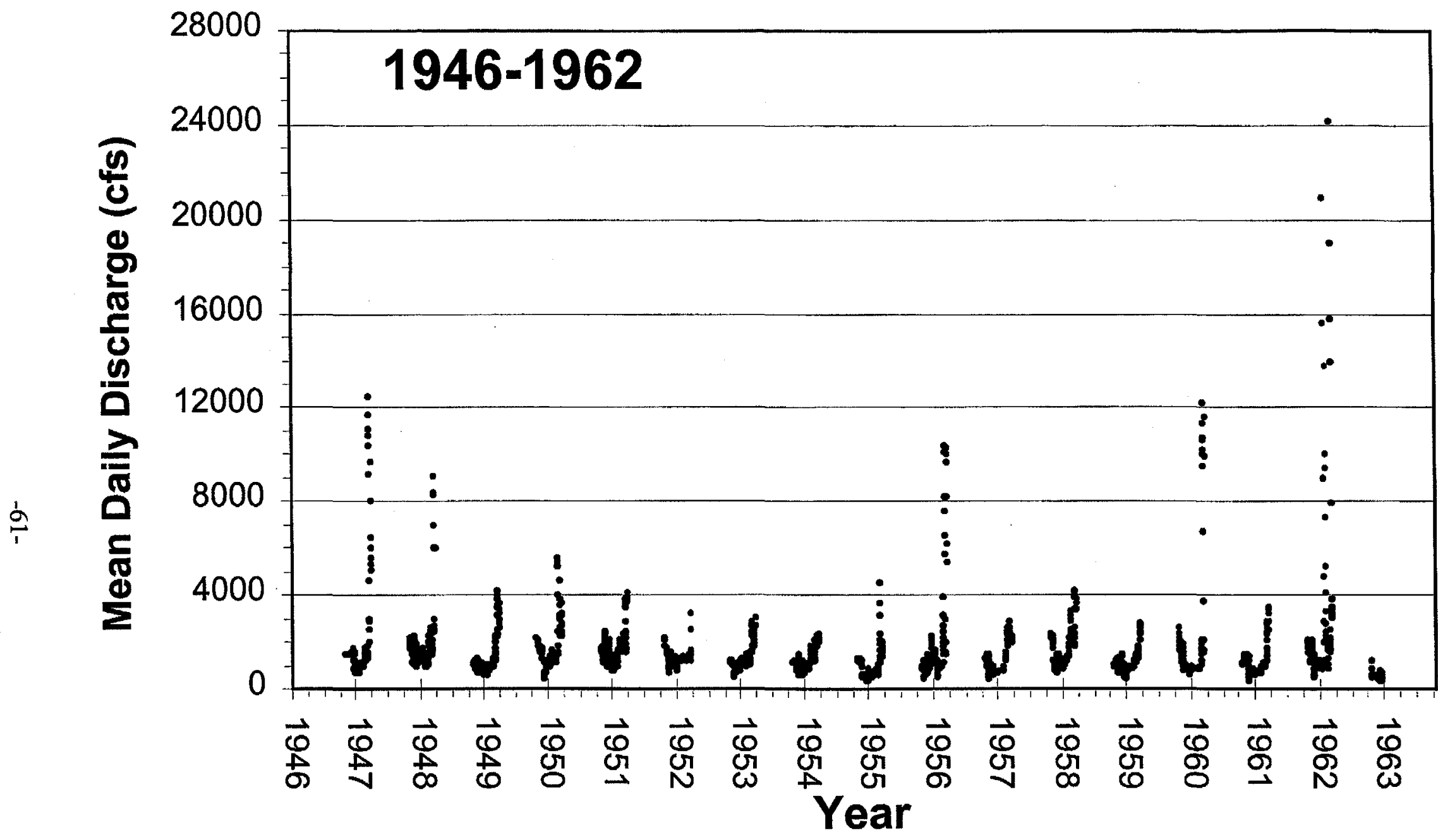

Figure 16. Mean daily discharge at the Jensen, Utah gage during the winter period (November through March) for the pre-dam years of record (1946-1962) 


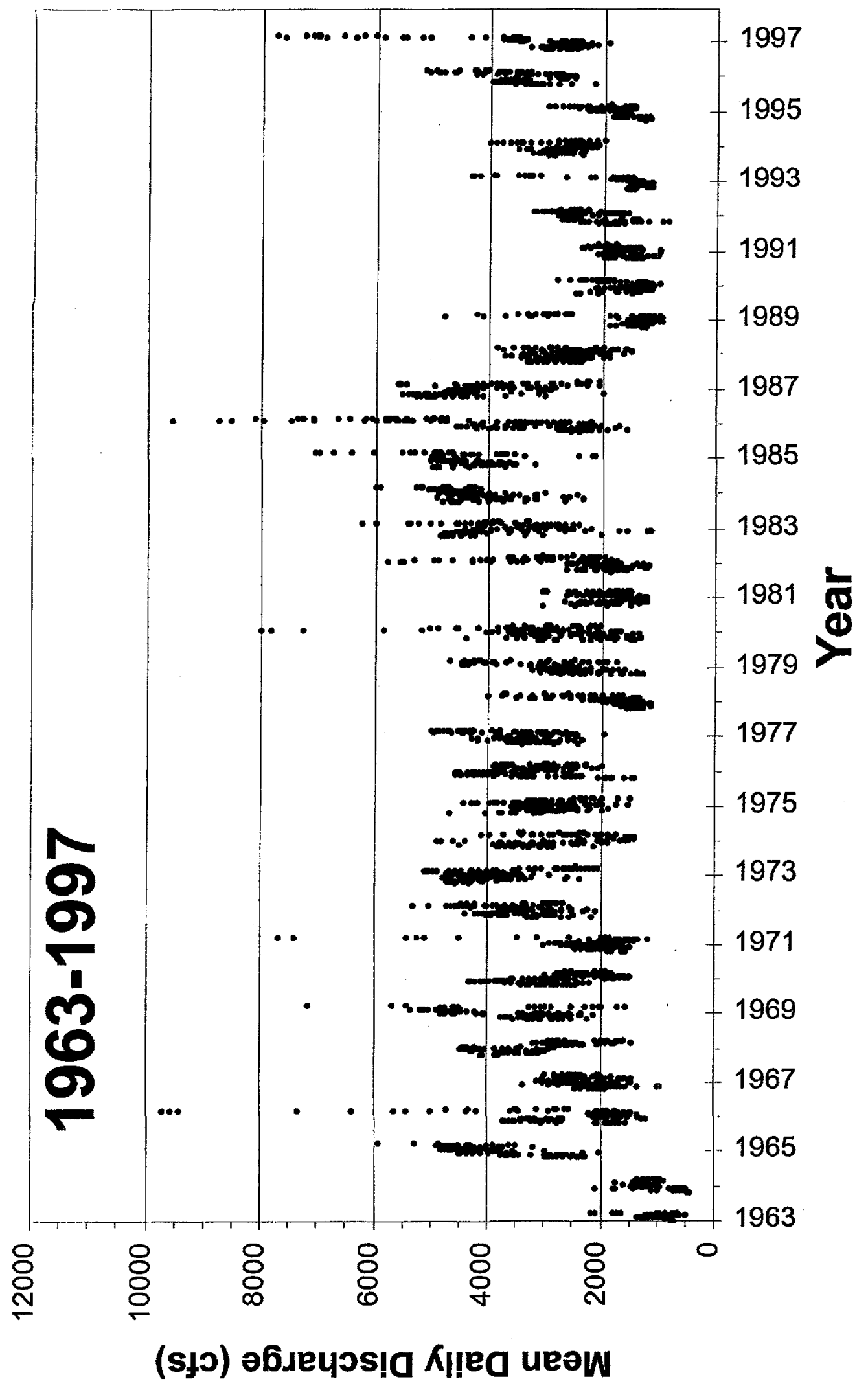

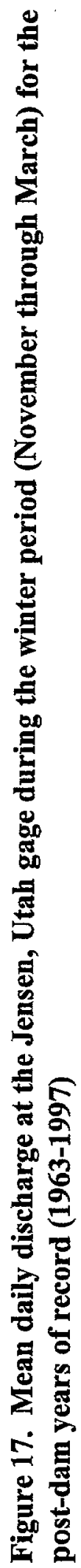




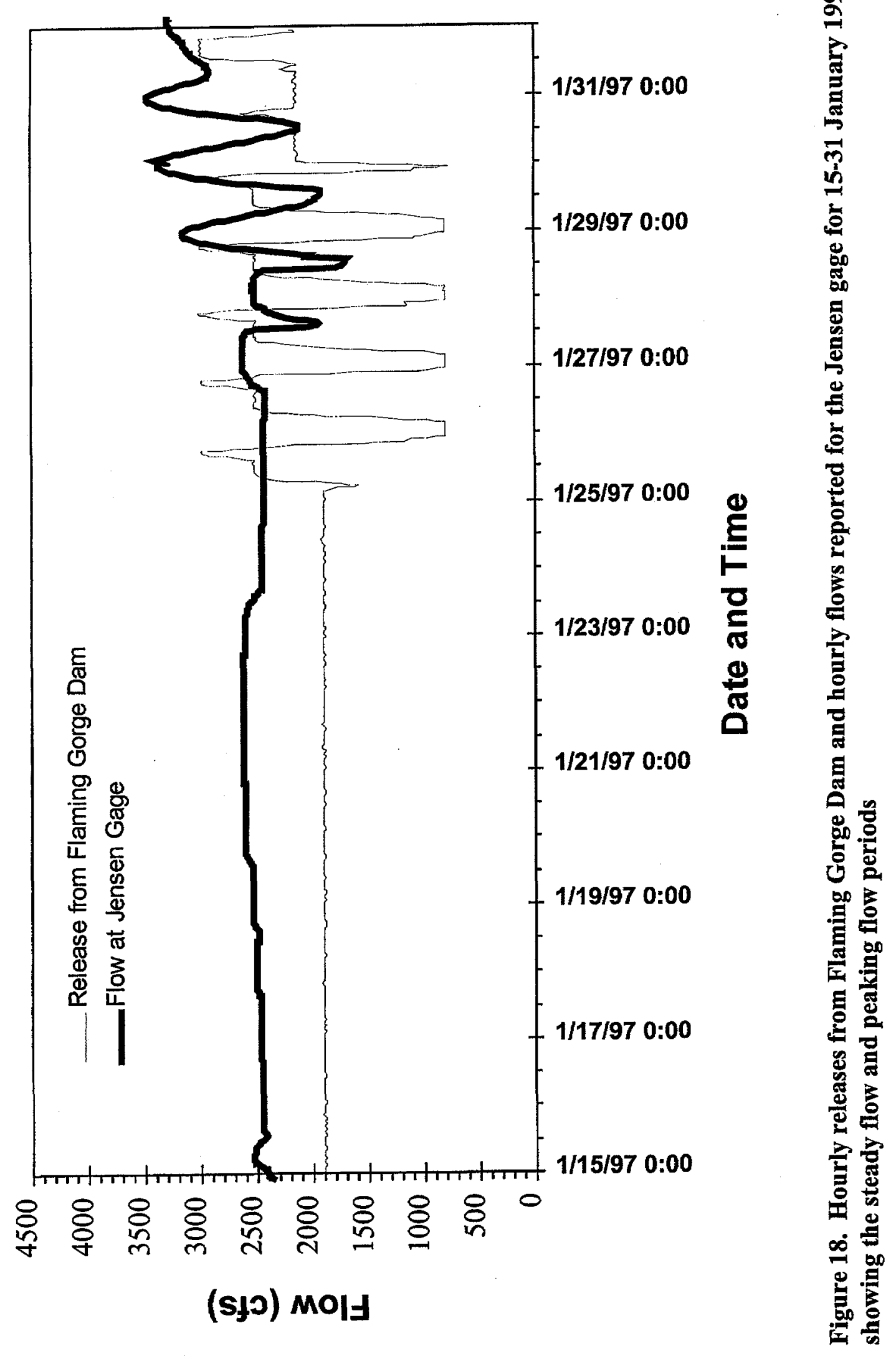




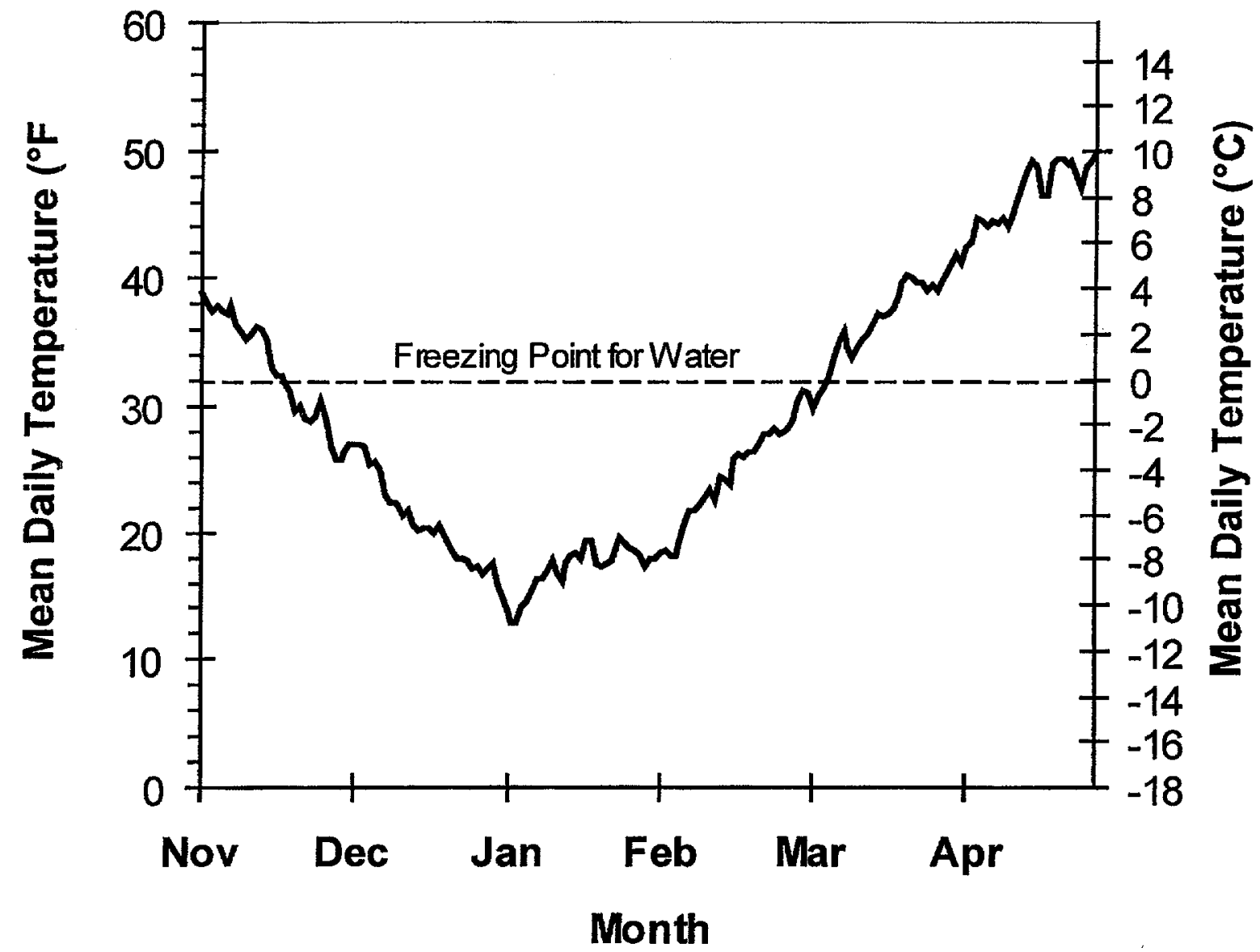

Figure 19. Mean daily air temperatures for Vernal, Utah from November through April based on records from 1945-1997 


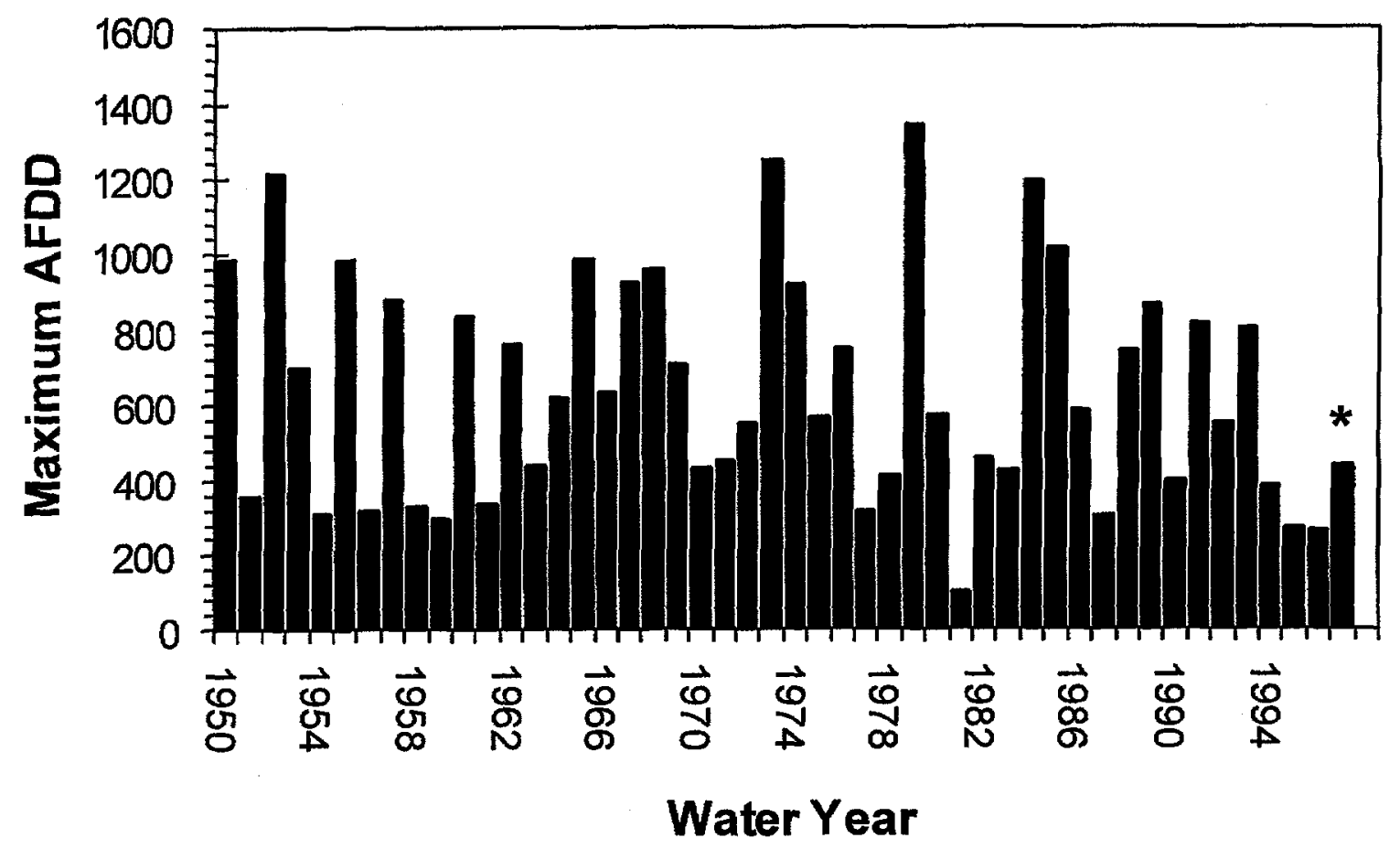

Figure 20. Maximum accumulated freezing degree days (AFDD) for 1950-1997. Note that the AFDD for a particular year includes the period from the November of the previous year through March of the year indicated. For example, the AFDD for 1990 (396 accumulated freezing degree days) was calculated for the period from November of 1989 through March of 1990. 


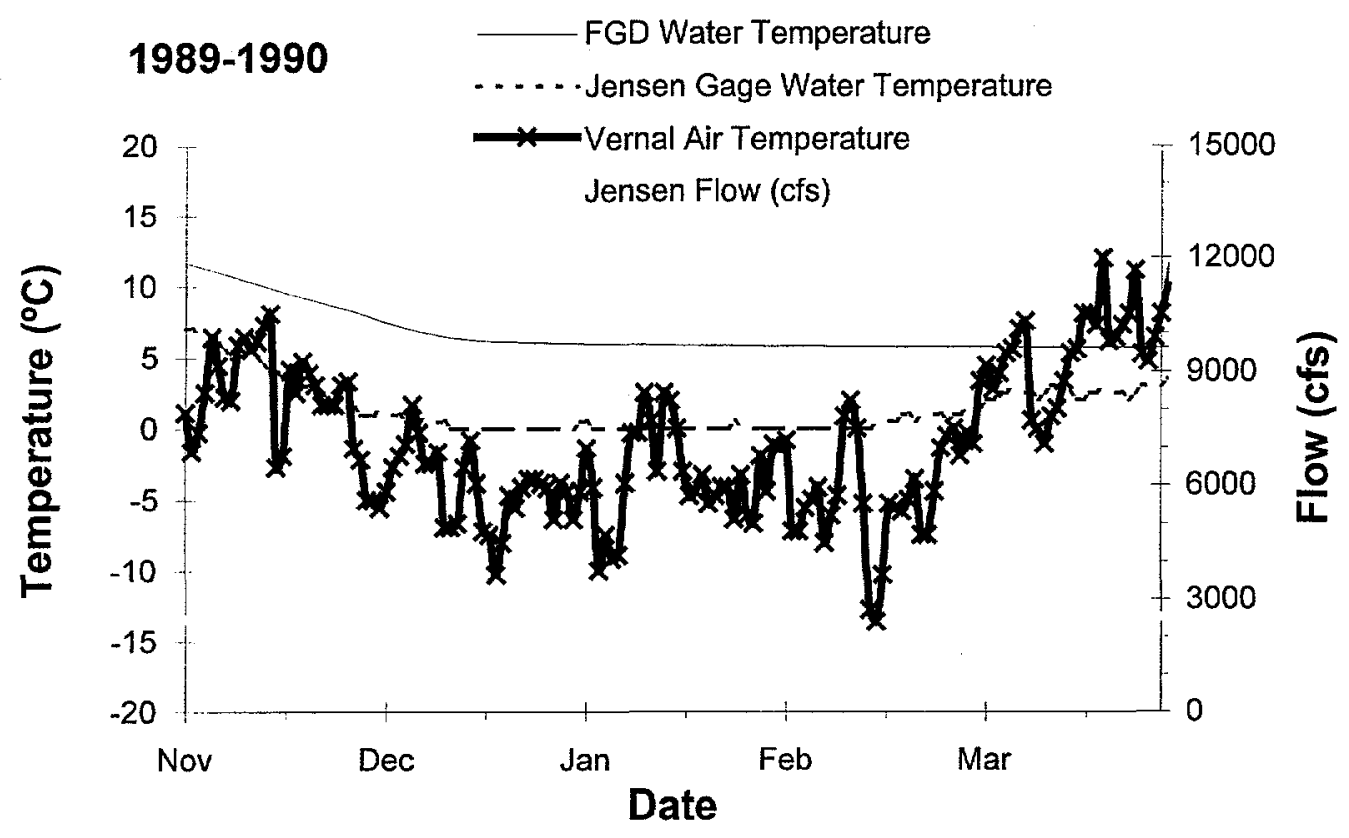

Figure 21. Water temperatures for Flaming Gorge Dam (FGD) releases and the Green River at the Jensen gage, air temperature for Vernal, Utah, and mean daily flow at the Jensen gage during the winter of 1989-1990 


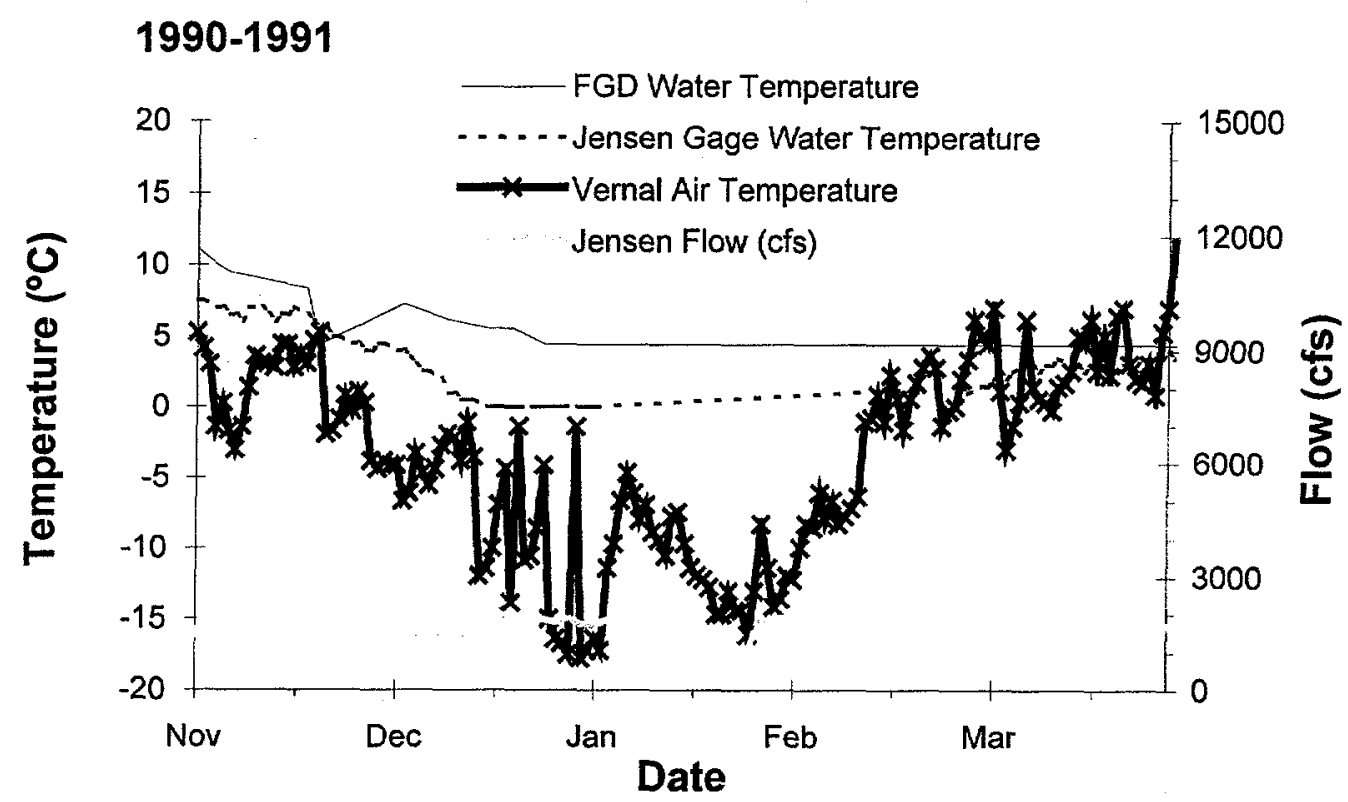

Figure 22. Water temperatures for Flaming Gorge Dam (FGD) releases and the Green River at the Jensen gage, air temperature for Vernal, Utah, and mean daily flow at the Jensen gage during the winter of 1990-1991 


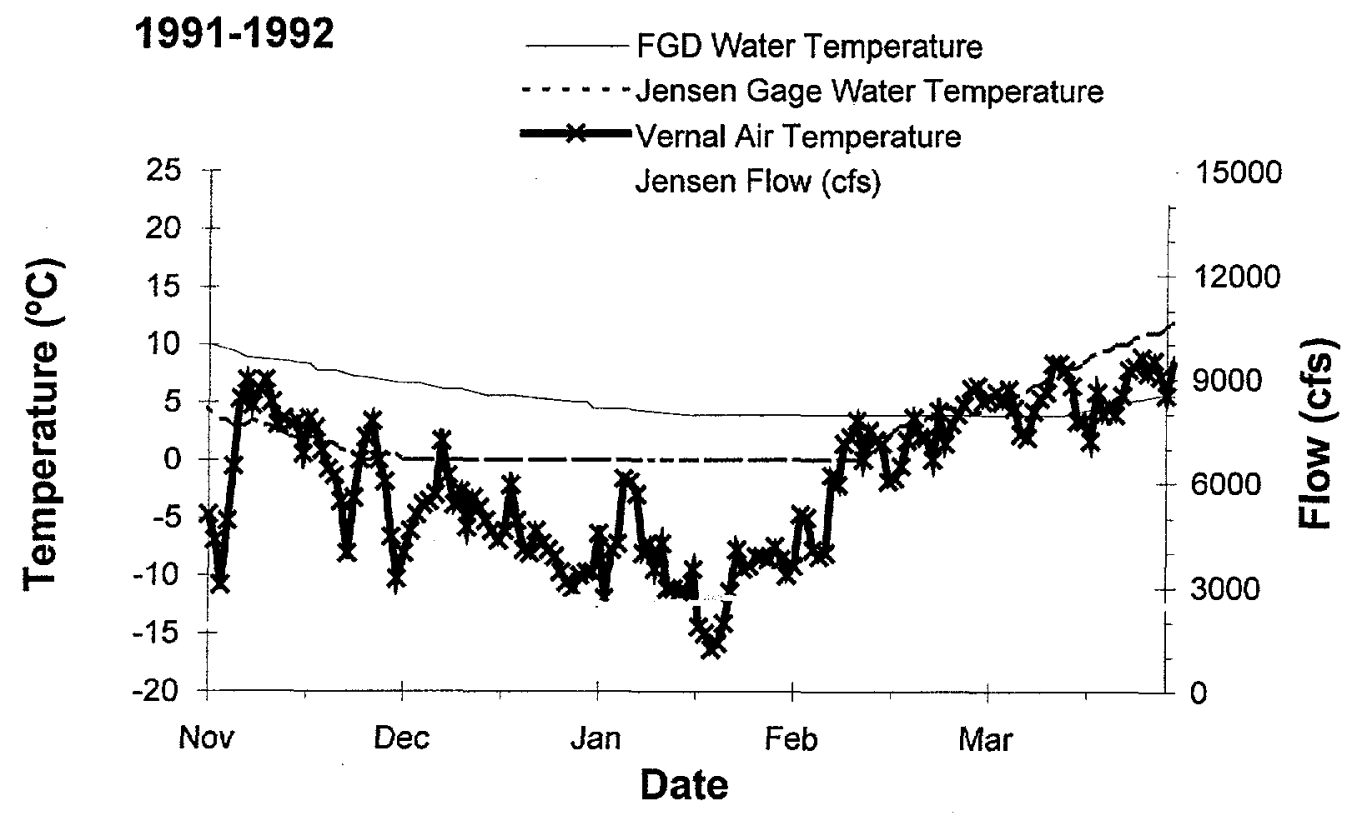

Figure 23. Water temperatures for Flaming Gorge Dam (FGD) releases and the Green River at the Jensen gage, air temperature for Vernal, Utah, and mean daily flow at the Jensen gage during the winter of 1991-1992 


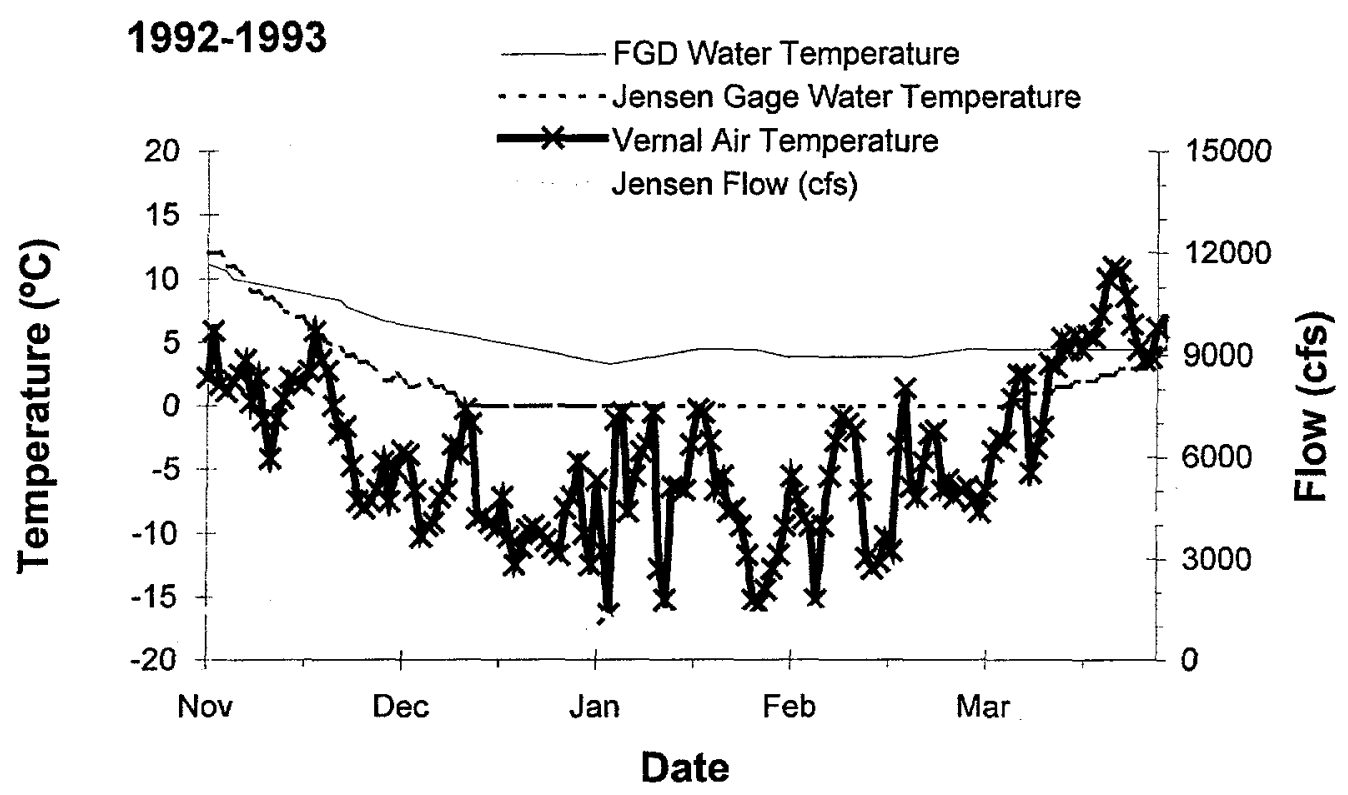

Figure 24. Water temperatures for Flaming Gorge Dam (FGD) releases and the Green River at the Jensen gage, air temperature for Vernal, Utah, and mean daily flow at the Jensen gage during the winter of 1992-1993 


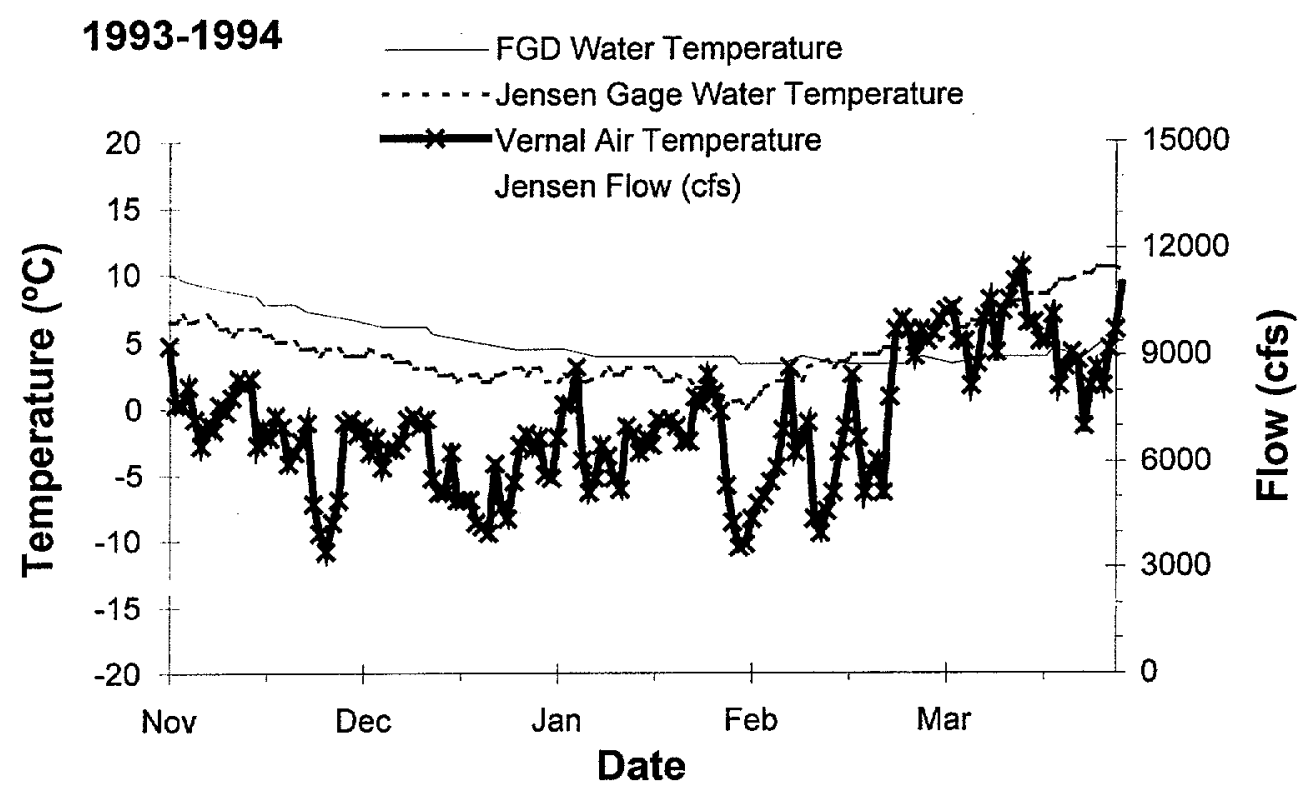

Figure 25. Water temperatures for Flaming Gorge Dam (FGD) releases and the Green River at the Jensen gage, air temperature for Vernal, Utah, and mean daily flow at the Jensen gage during the winter of 1993-1994 


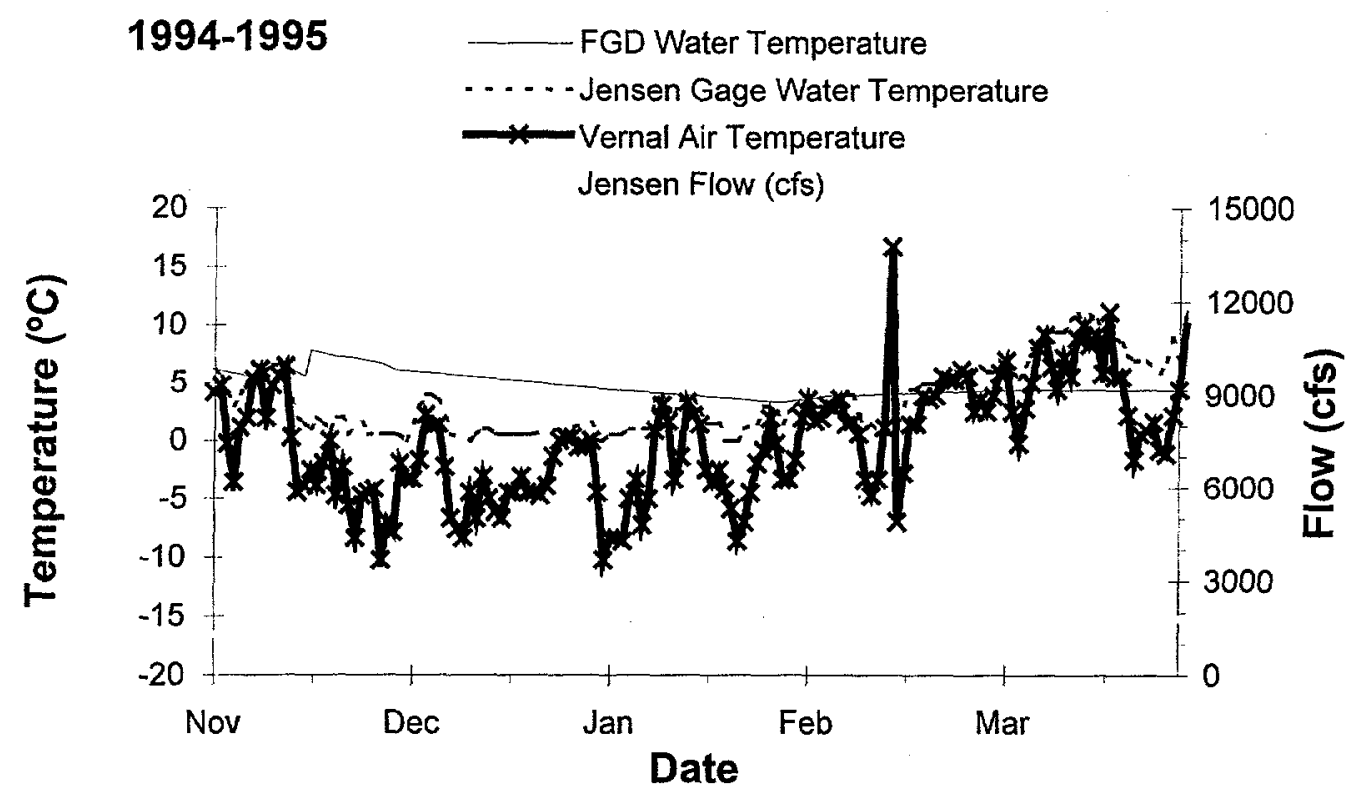

Figure 26. Water temperatures for Flaming Gorge Dam (FGD) releases and the Green River at the Jensen gage, air temperature for Vernal, Utah, and mean daily flow at the Jensen gage during the winter of 1994-1995 


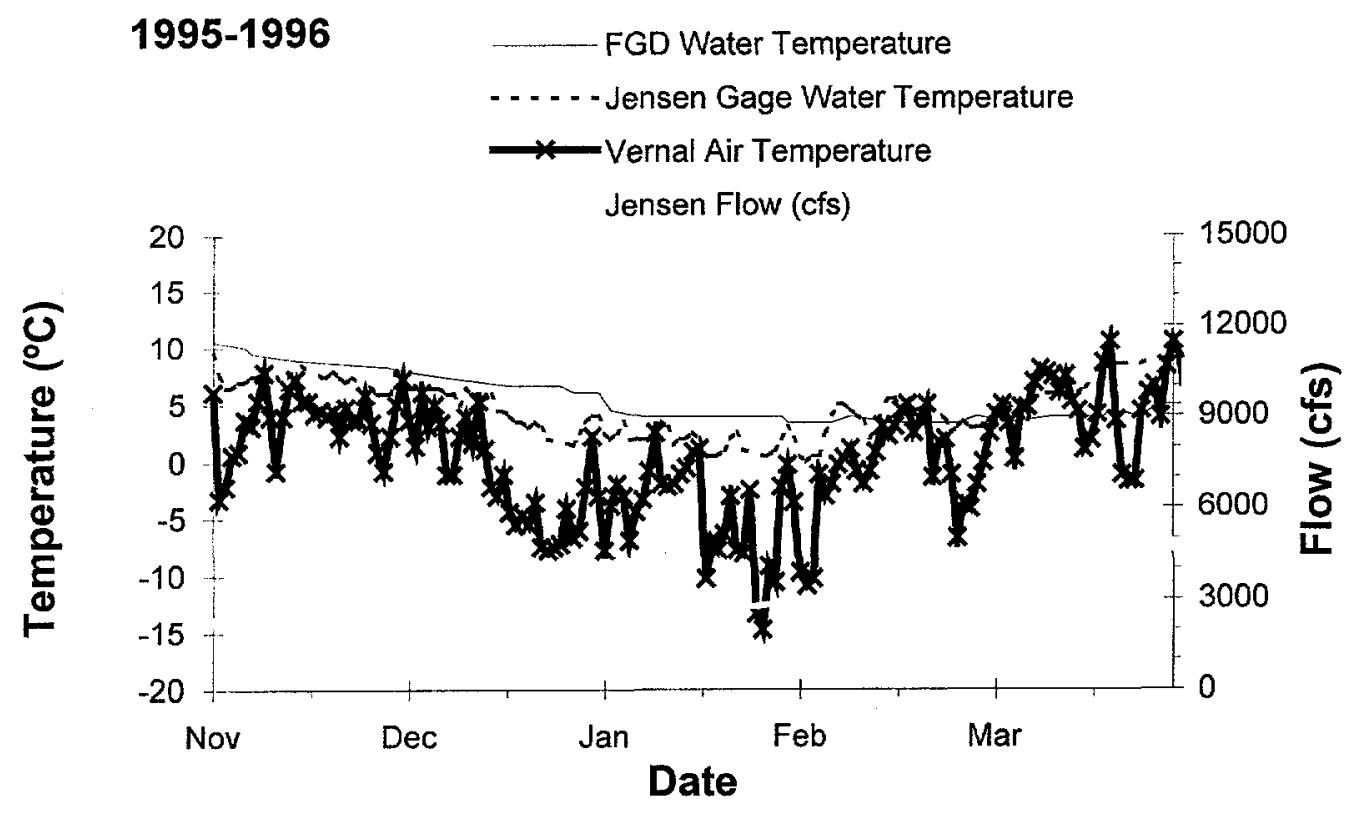

Figure 27. Water temperatures for Flaming Gorge Dam (FGD) releases and the Green River at the Jensen gage, air temperature for Vernal, Utah, and mean daily flow at the Jensen gage during the winter of 1995-1996 


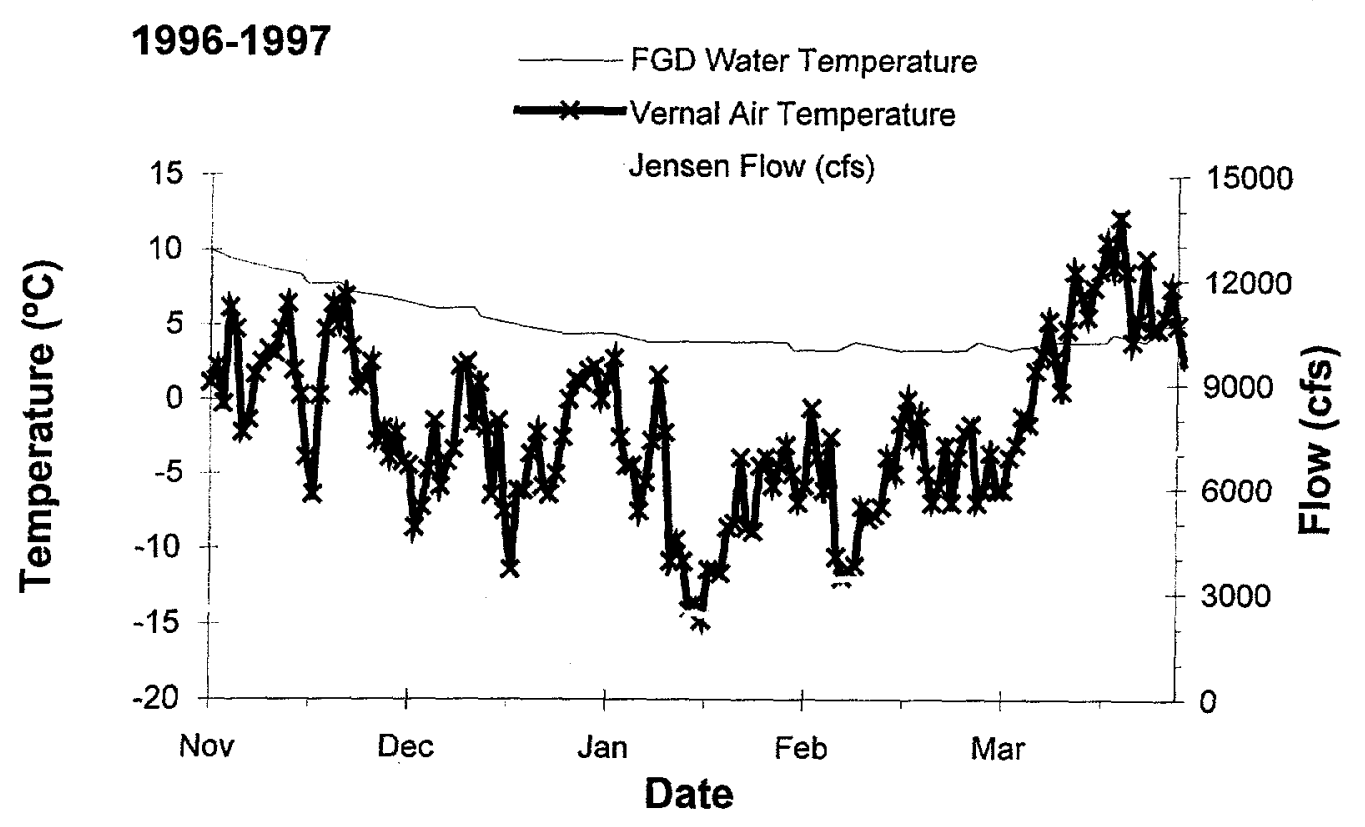

Figure 28. Water temperatures for Flaming Gorge Dam (FGD) releases, air temperature for Vernal, Utah, and mean daily flow at the Jensen gage during the winter of 1996-1997 


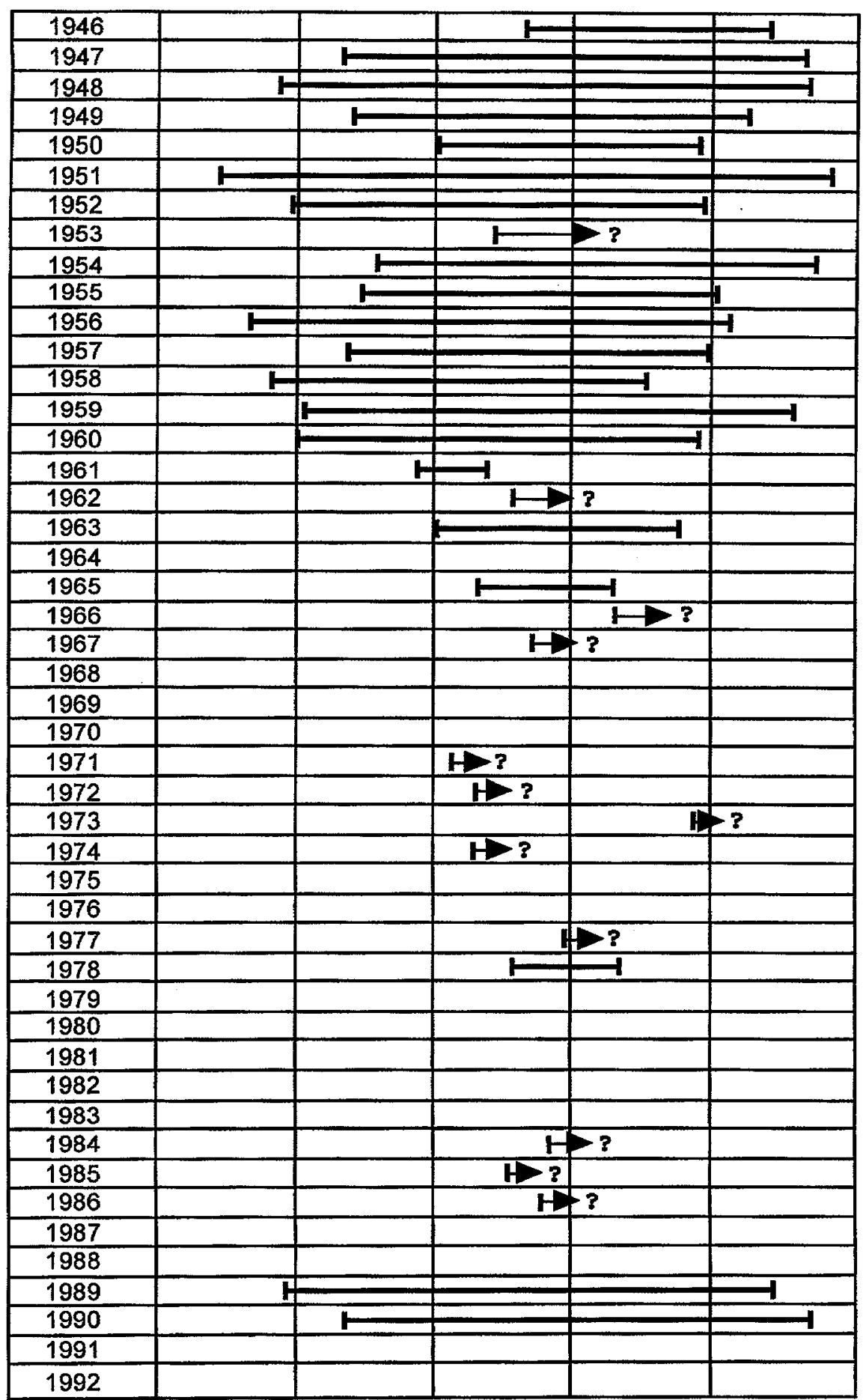

Figure 29. Summary of USGS ice observations. Note that the presented information covers the period from November of the previous year through March of the year indicated. 


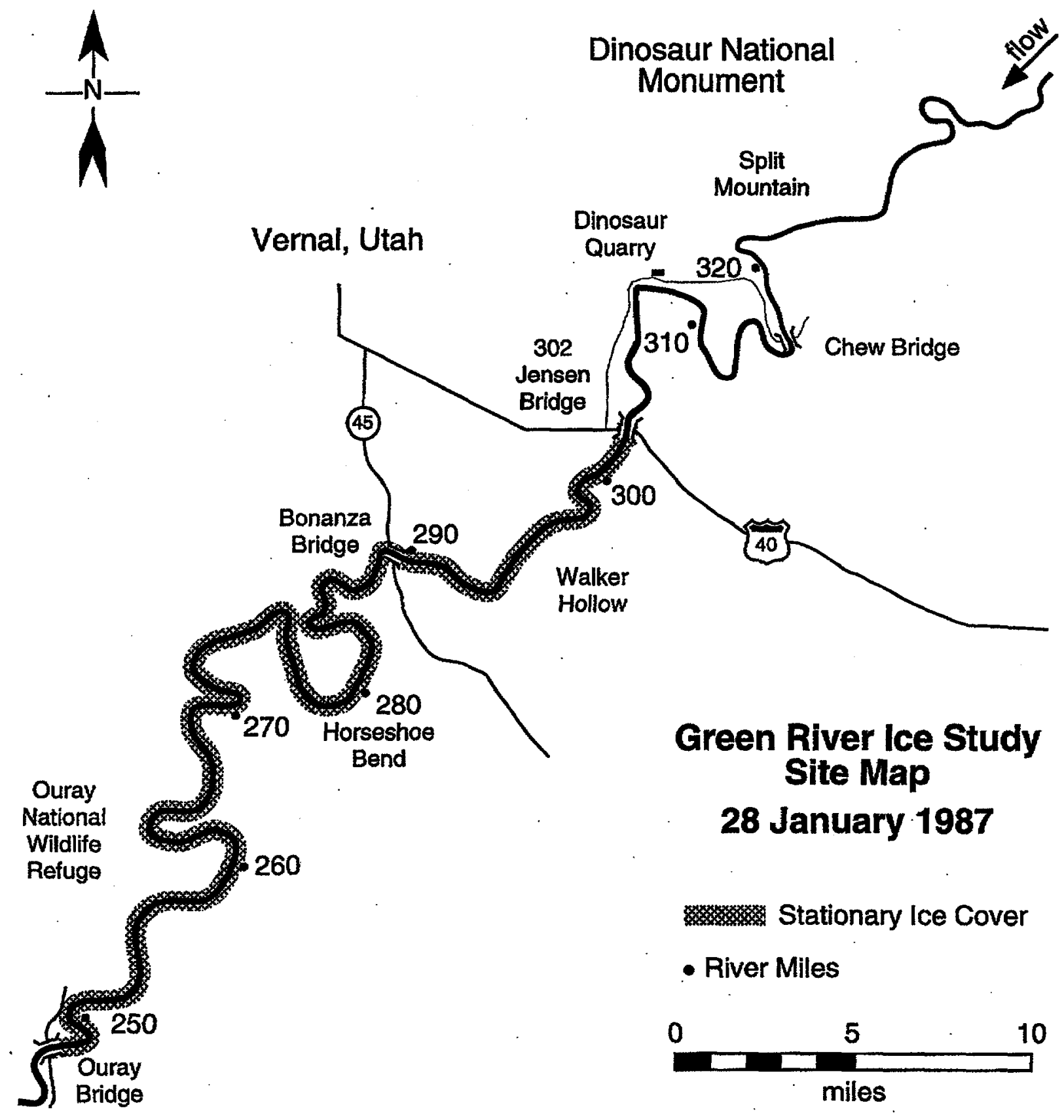

Figure 30. Observed extent of ice on 28 January 1987. (Source: Valdez and Masslich 1989) 


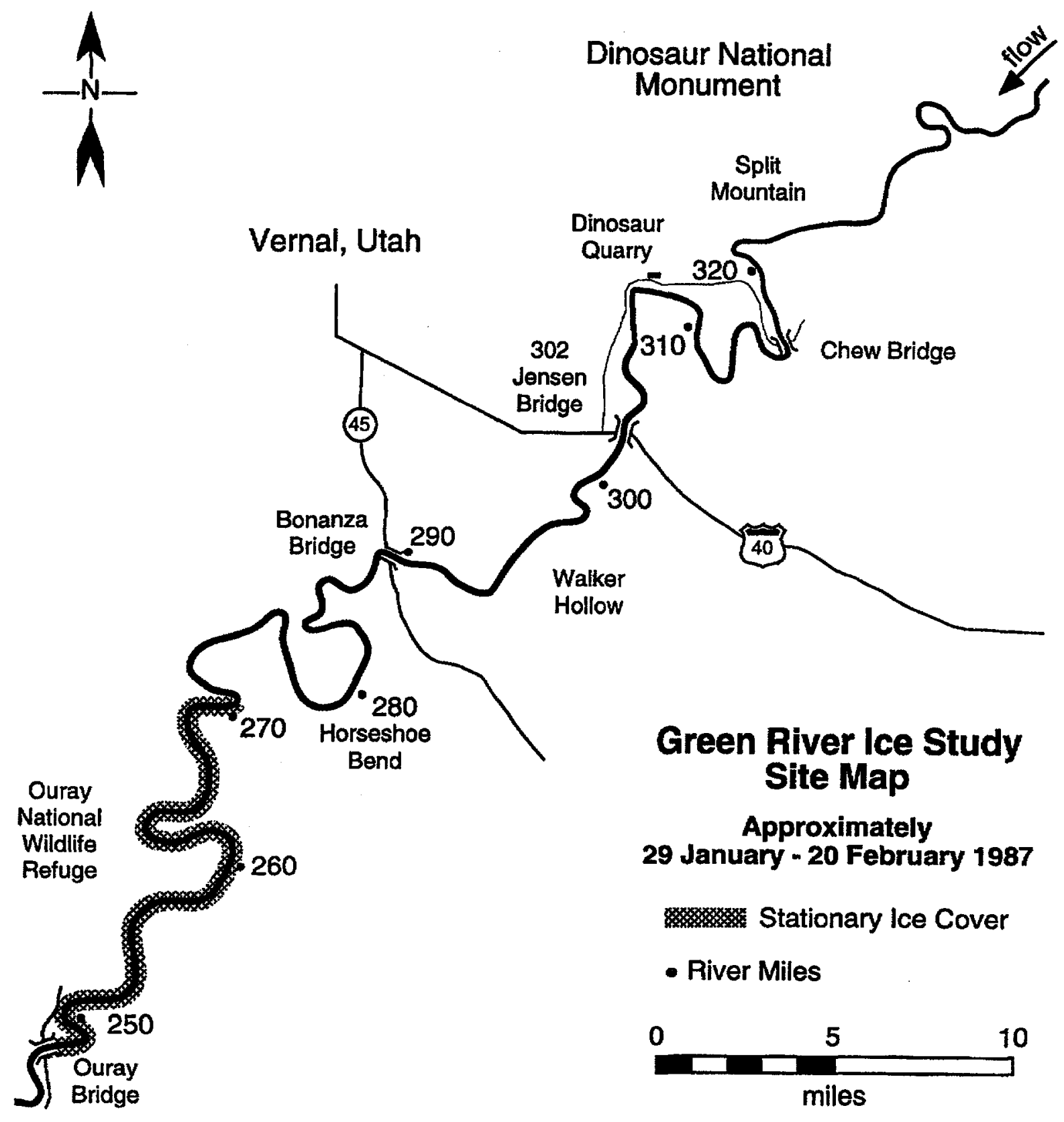

Figure 31. Observed extent of ice on 29 January to 20 February 1987. (Source: Valdez and Masslich 1989) 

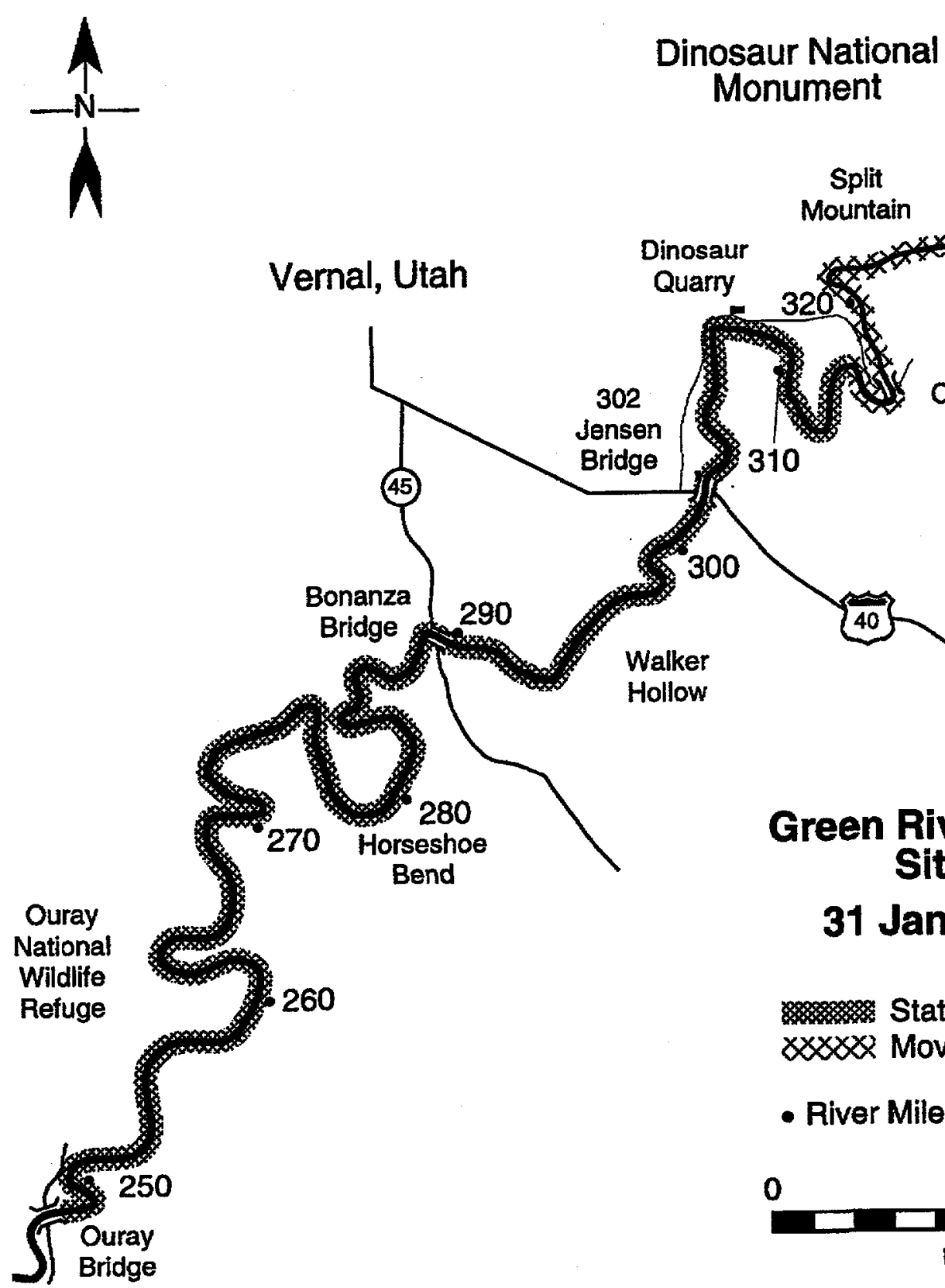

\section{Green River Ice Study Site Map \\ 31 January 1988}

Walker

Hollow

Stationary lce Cover $\triangle X X \times X \times$ Moving lce

- River Miles

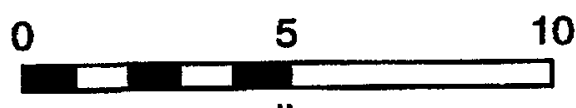

miles

Figure 32. Observed extent of ice on 31 January 1988. (Source: Valdez and Masslich 1989) 

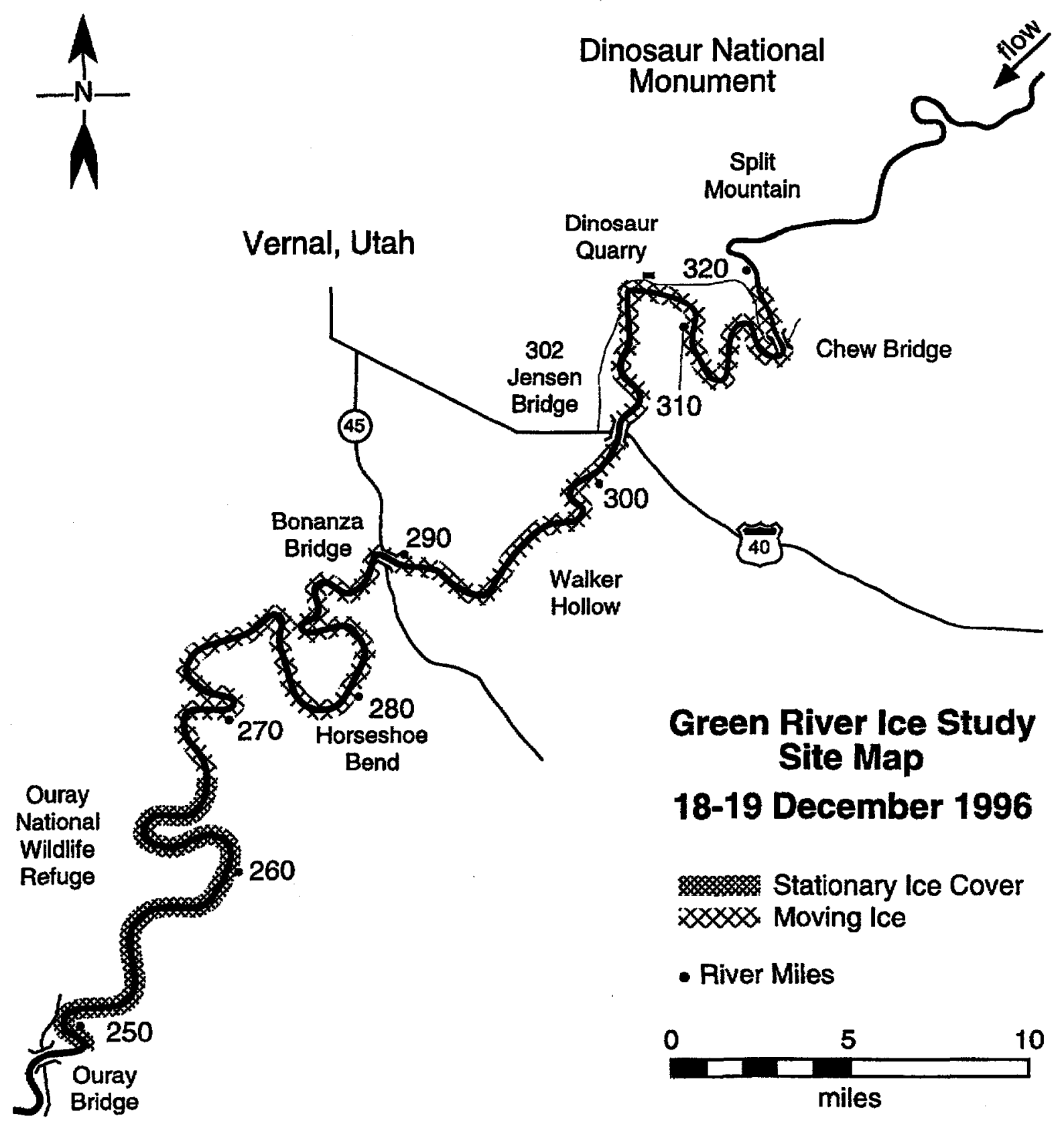
$x \times x \times x$. Moving lce

- River Miles

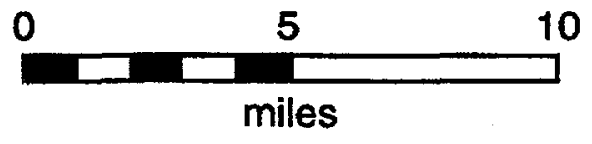

Figure 33. Observed extent of ice on 18 to 19 December 1996. 


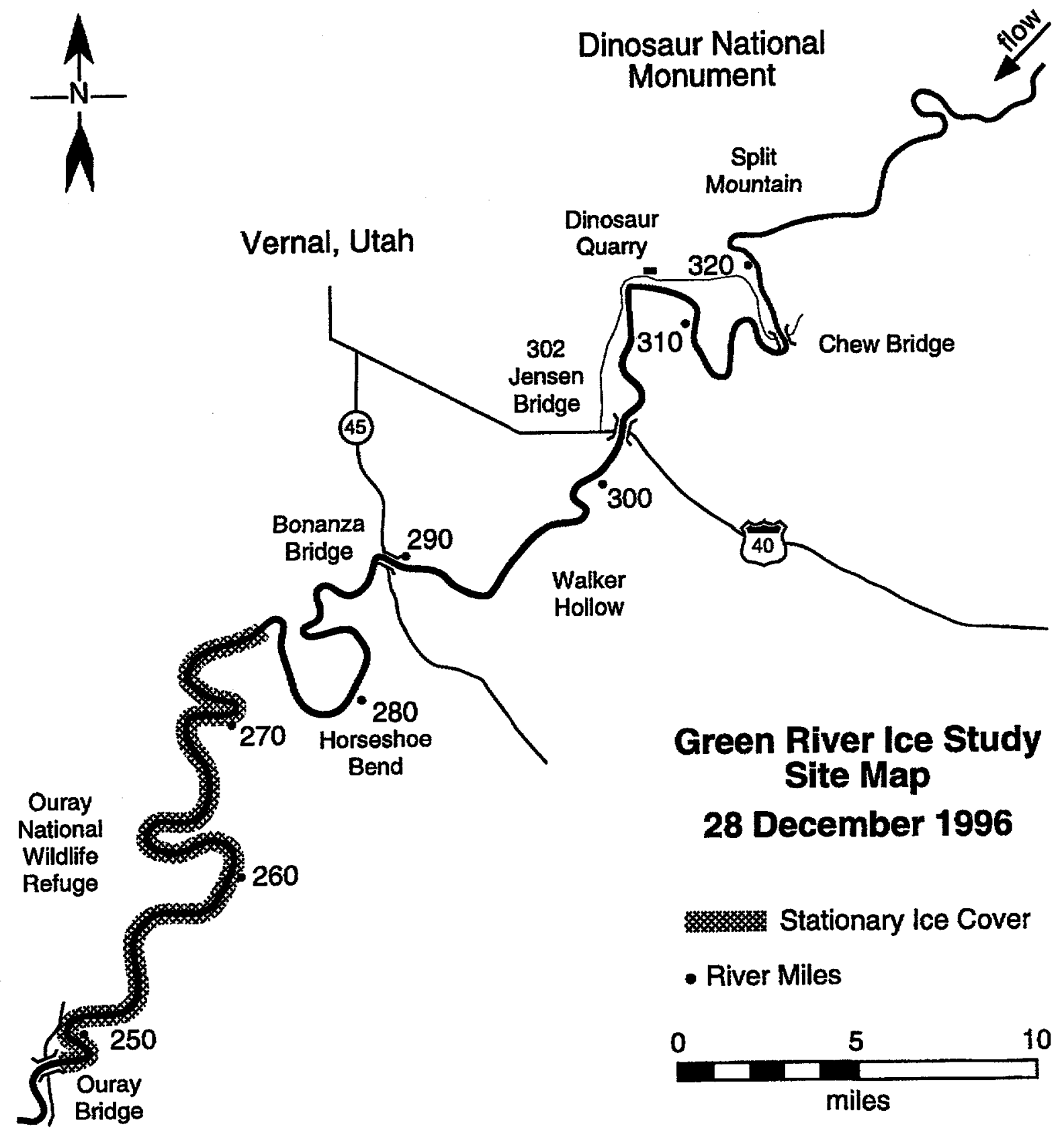

Figure 34. Observed extent of ice on 28 December 1996. 


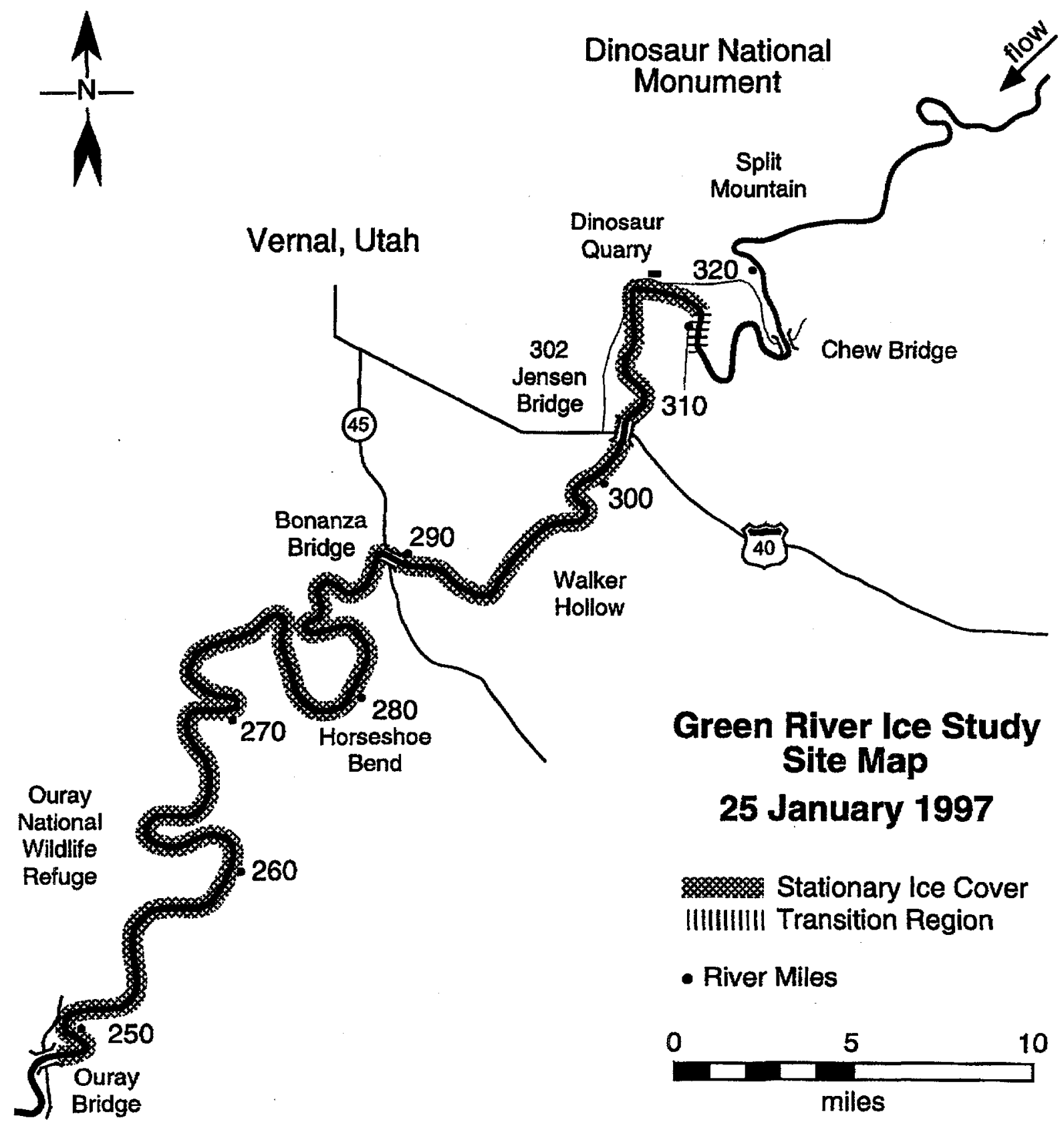

Figure 35. Observed extent of ice on 25 January 1997 


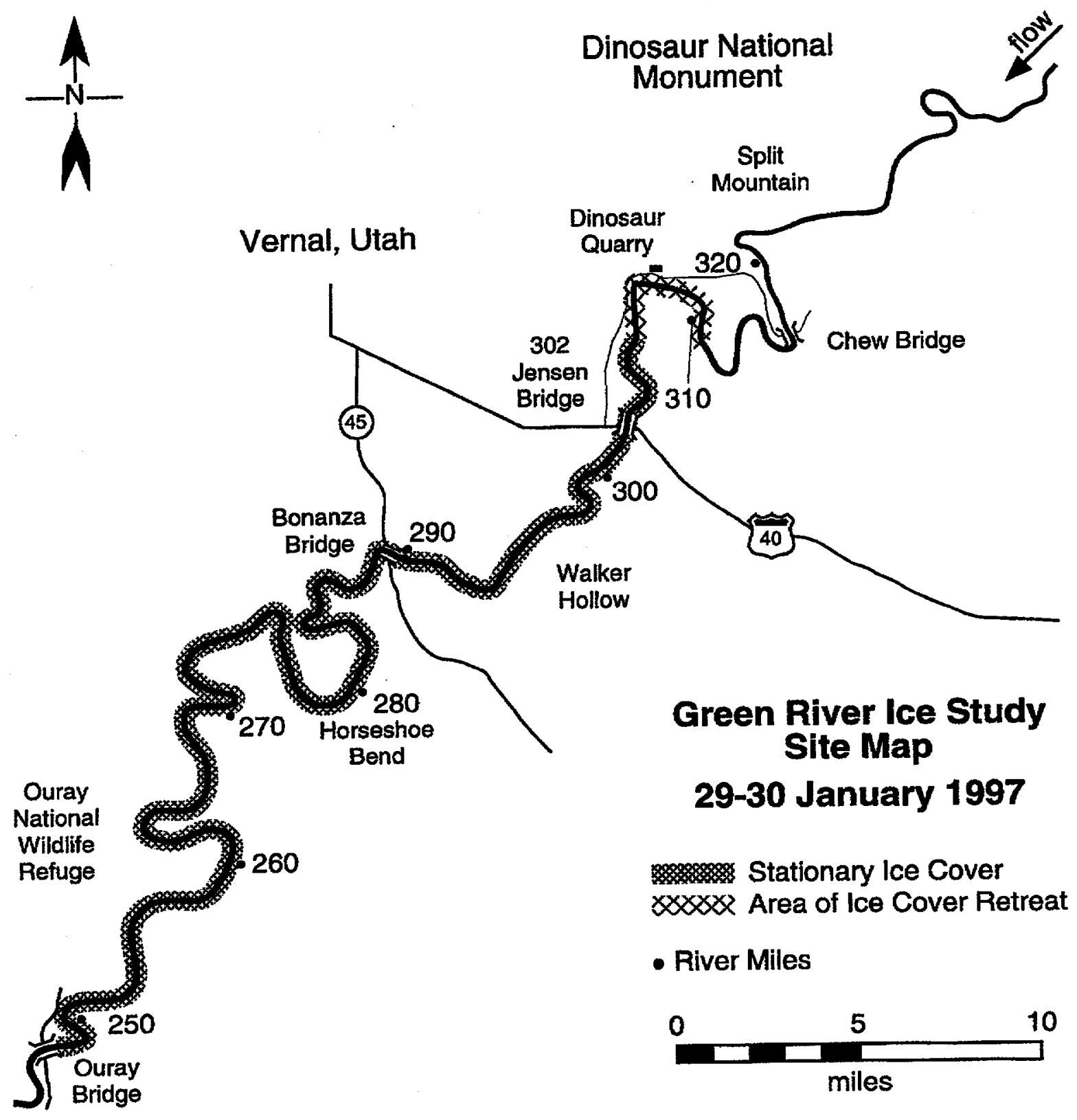

Figure 36. Observed extent of ice on 29-30 January 1997. 


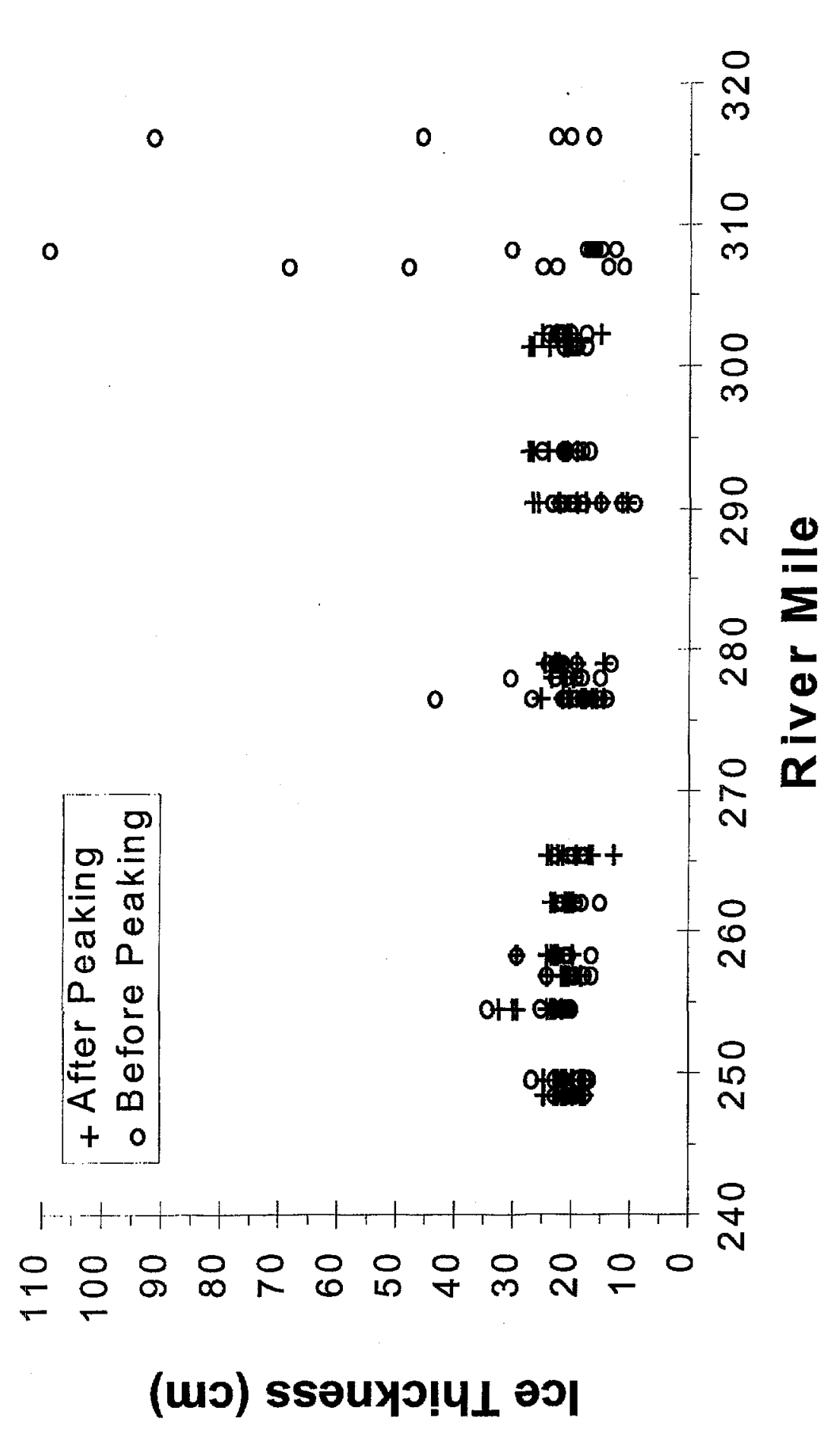

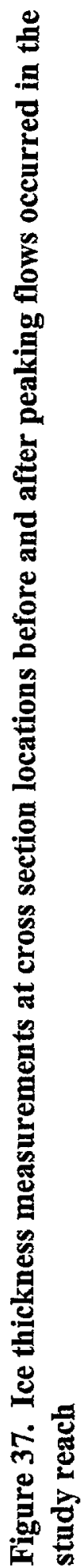


$01 / 2812: 00$

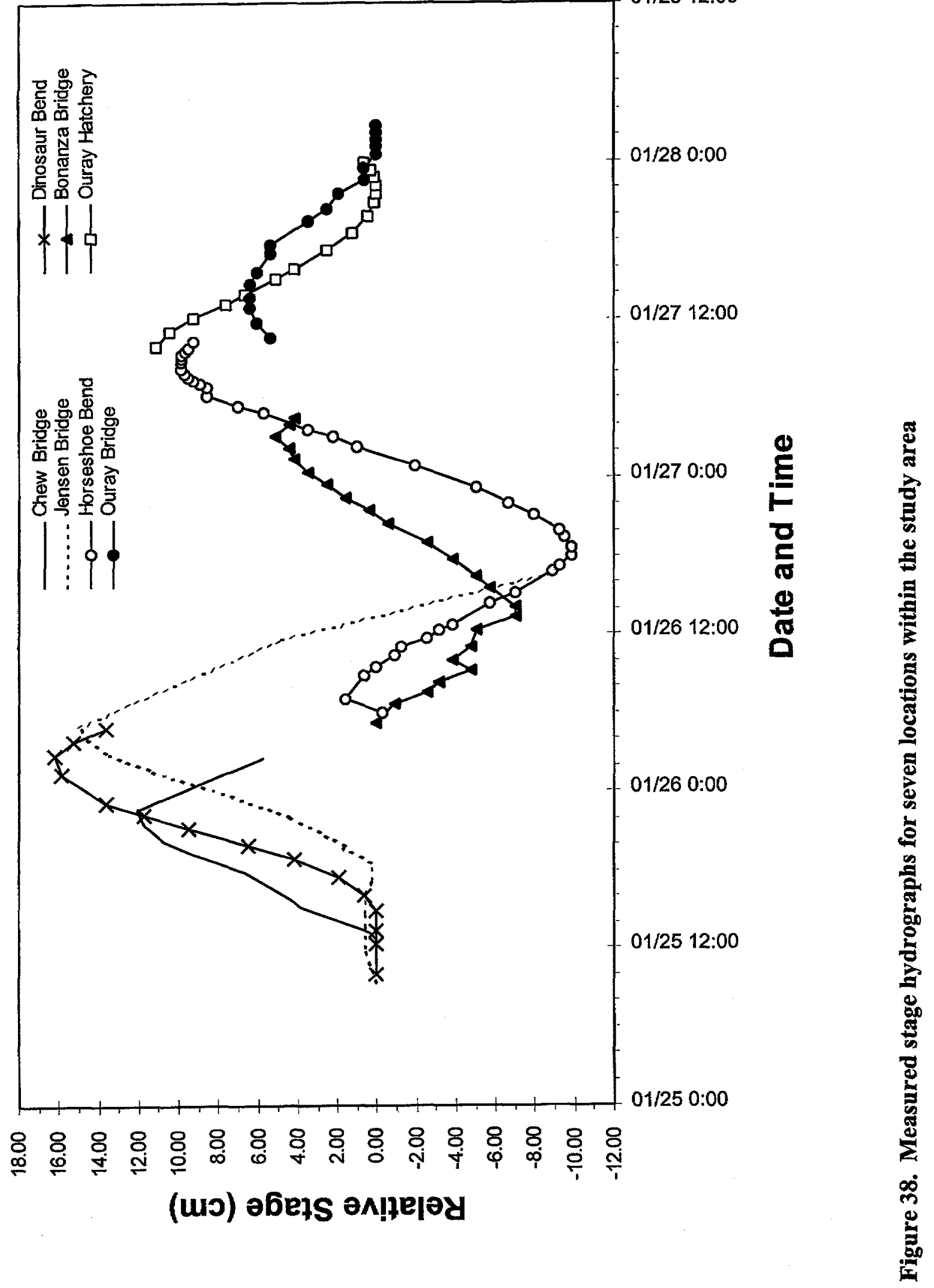




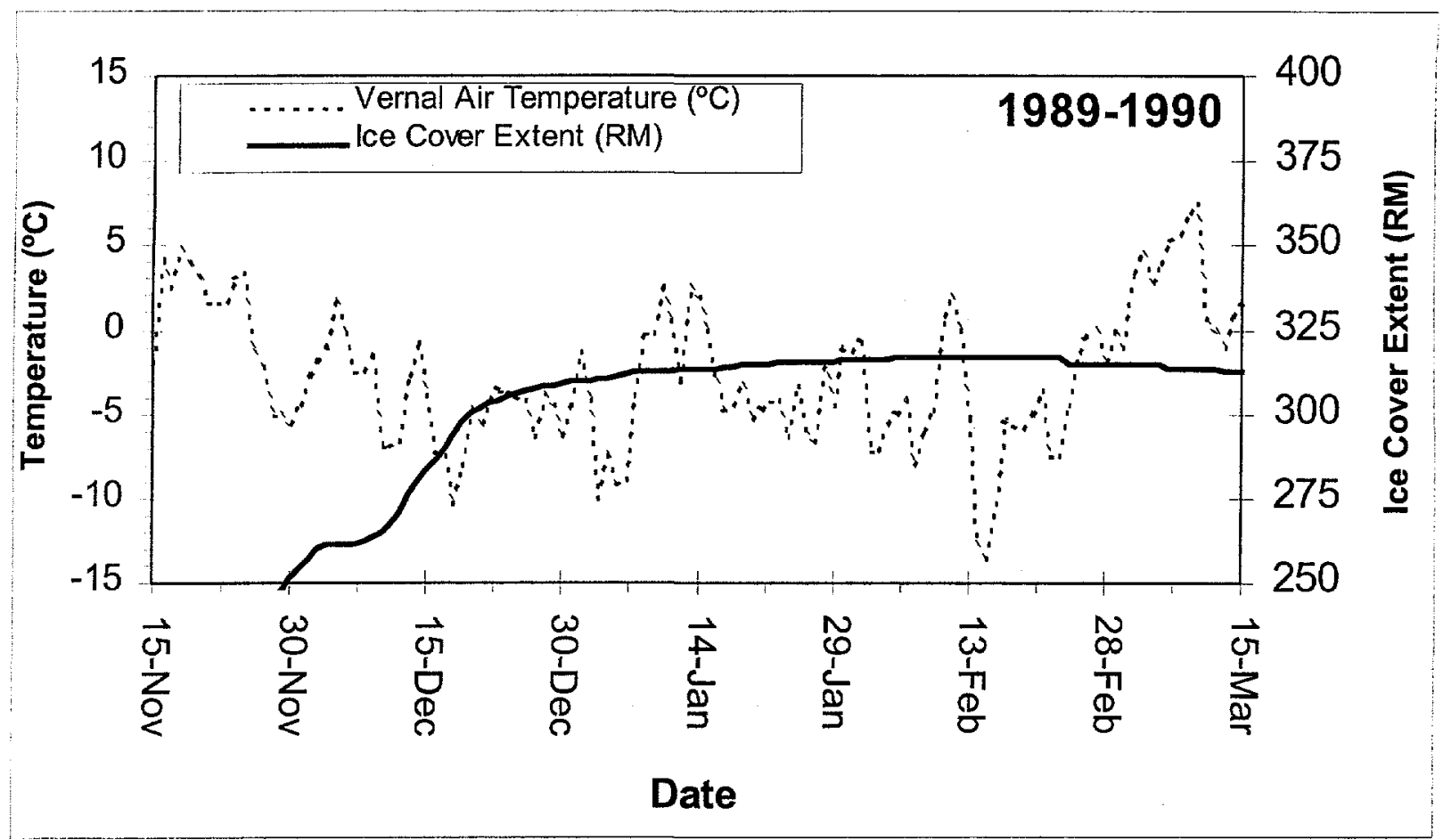

Figure 39. Ice model results for the winter of 1989-1990 


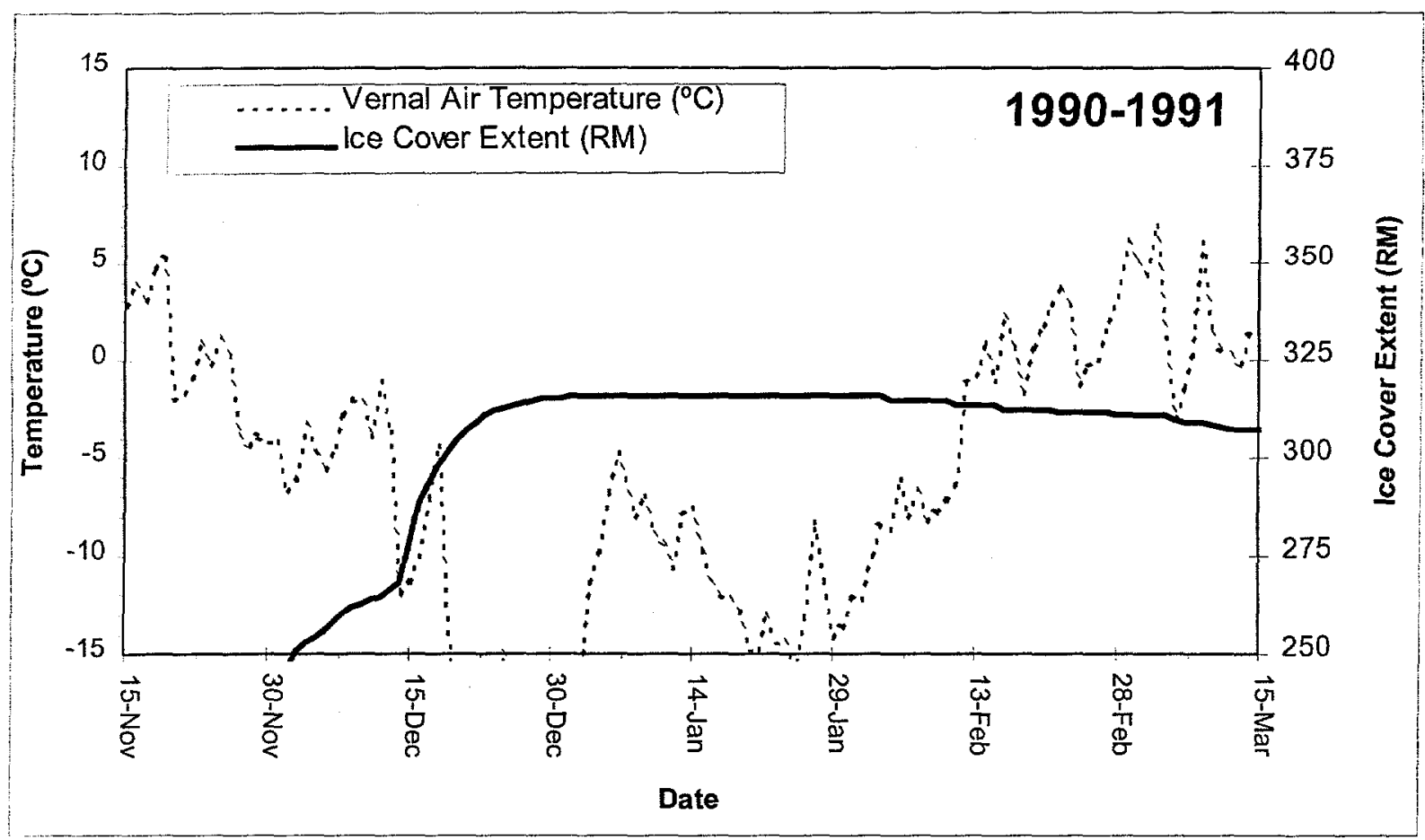

Figure 40. Ice model results for the winter of 1990-1991 


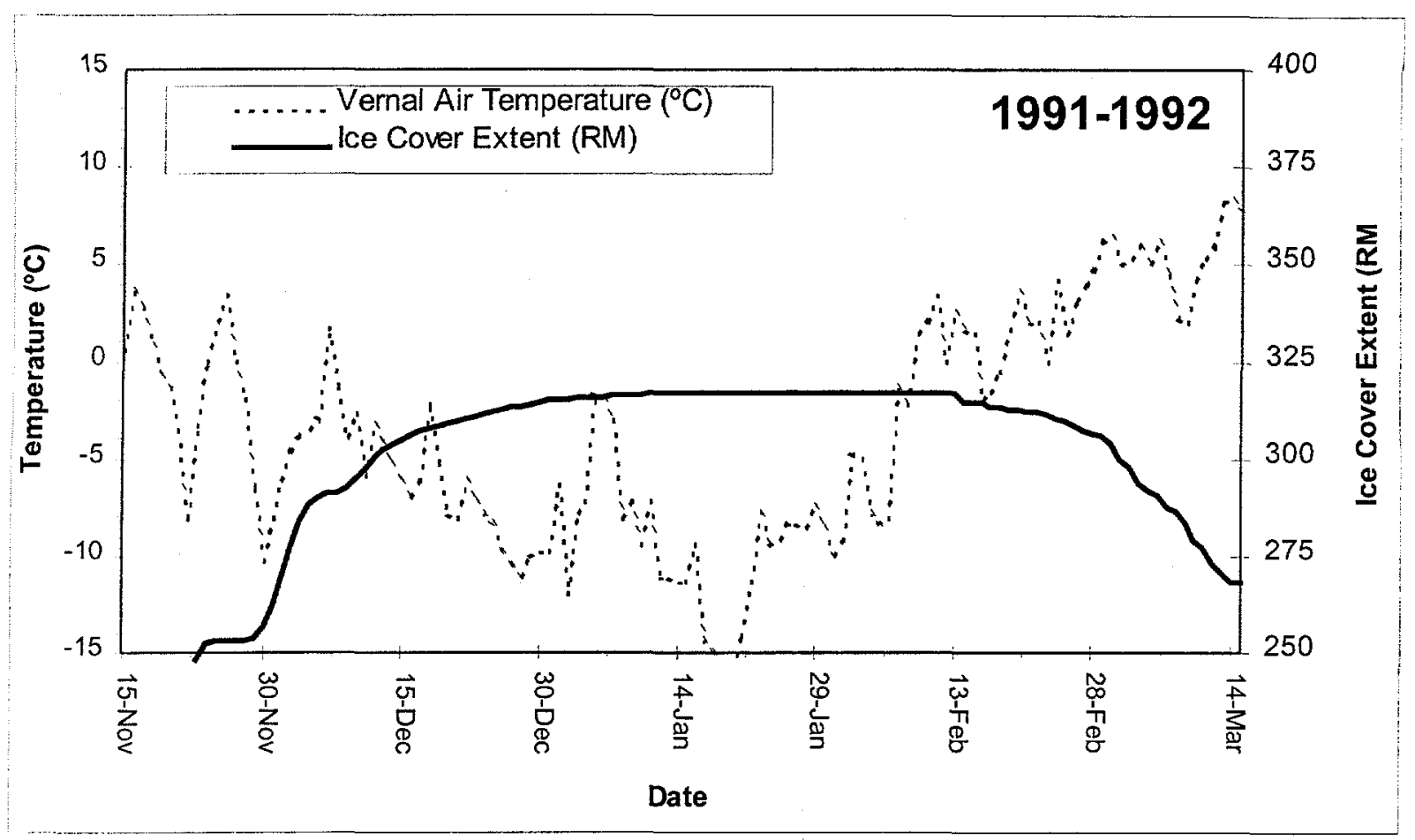

Figure 41. Ice model results for the winter of 1991-1992 


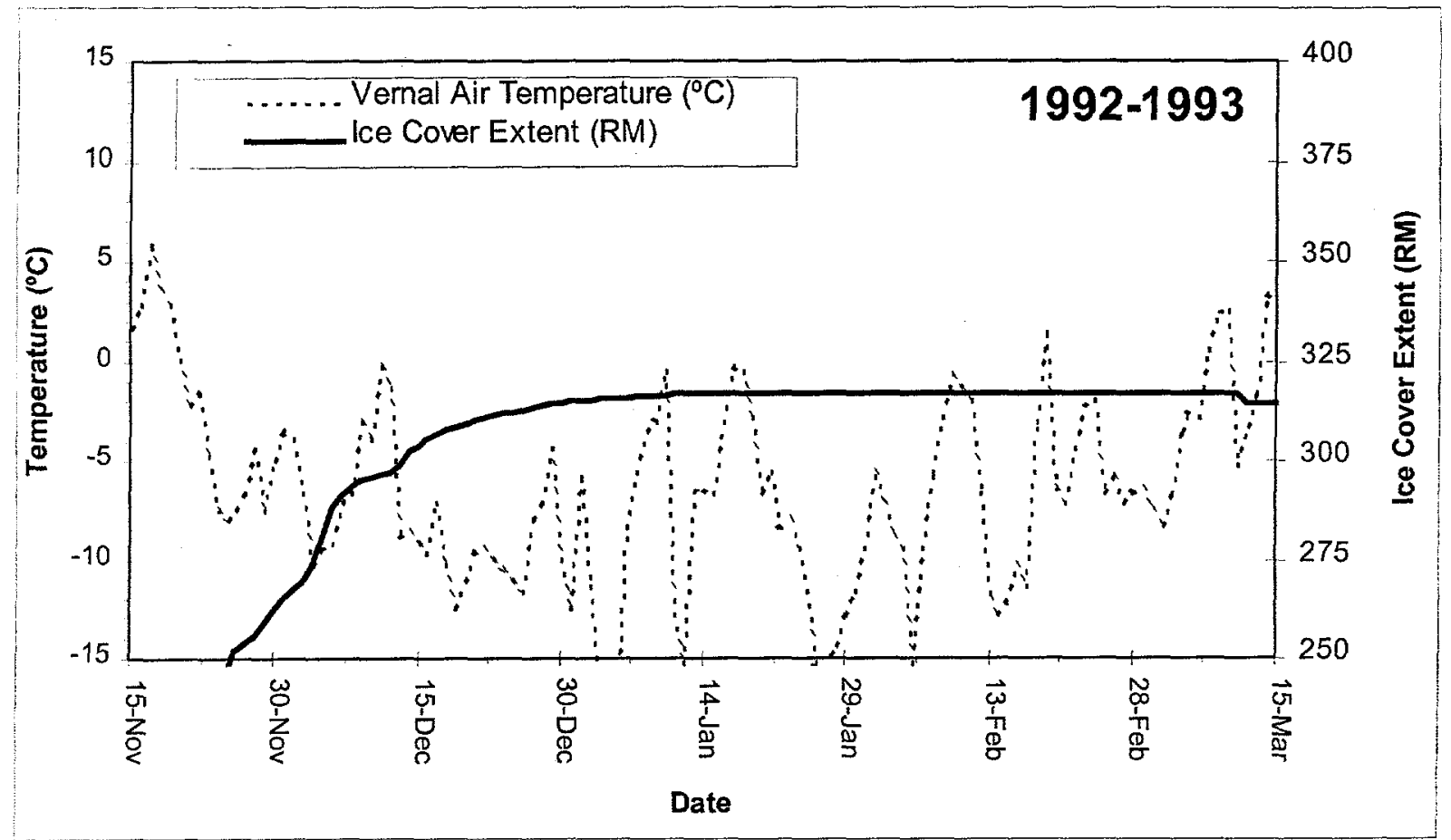

Figure 42. Ice model results for the winter of 1992-1993 


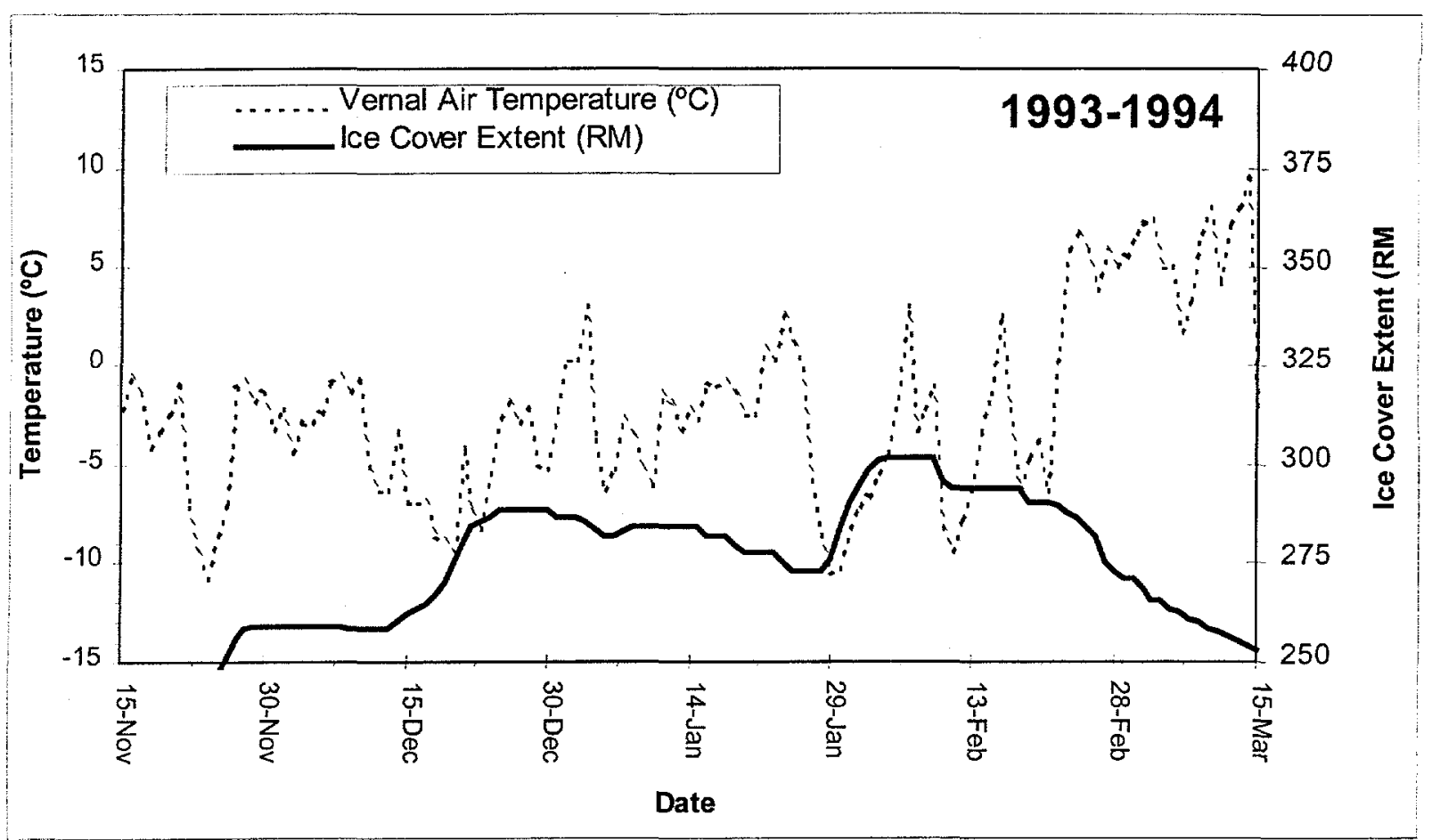

Figure 43. Ice model results for the winter of 1993-1994 


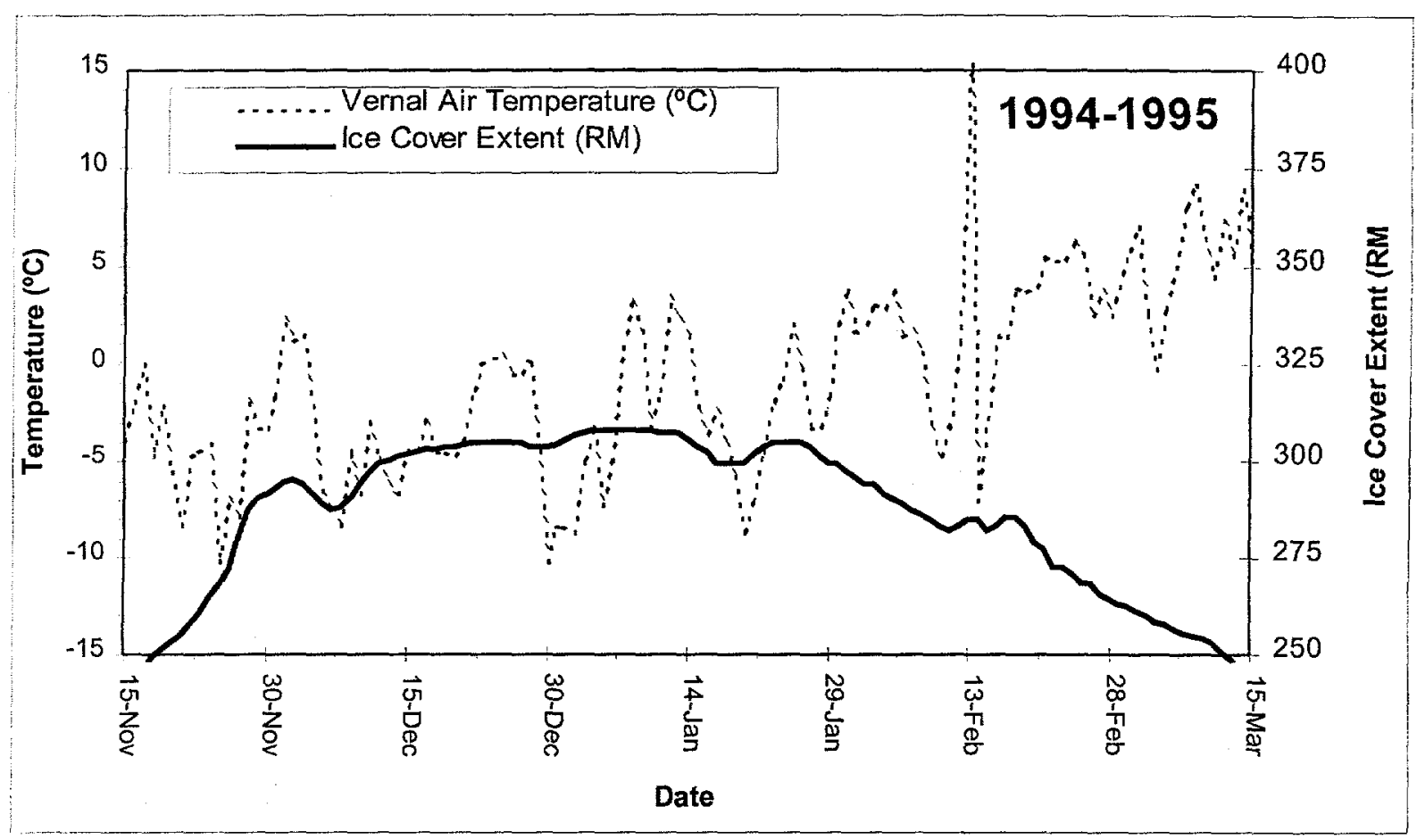

Figure 44. Ice model results for the winter of 1994-1995 


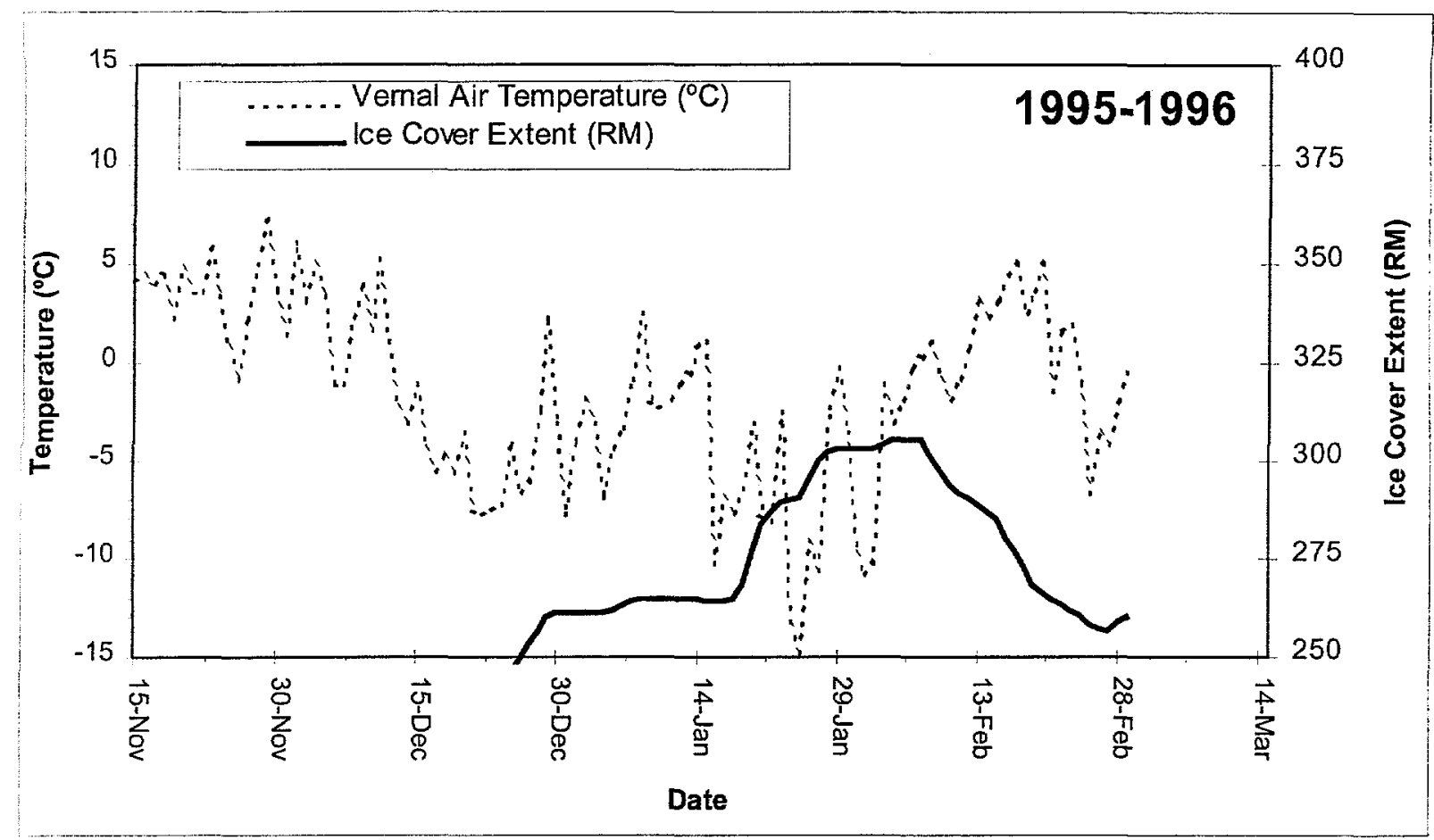

Figure 45. Ice model results for the winter of 1995-1996 


\section{APPENDIX}

Ice Conditions at Cross-section Locations During the 1997 Field Surveys 
Green River Ice Thickness Survey

\section{Location: RM $248.42000 \mathrm{ft}$ upstream of Ouray Bridge}

During Steady Flow Period @ 0845 hr 1/23/97

\begin{tabular}{lccc} 
& $\begin{array}{c}\text { Station } \\
(\mathrm{t})\end{array}$ & $\begin{array}{c}\text { Ice } \\
\text { Thickness } \\
(\mathrm{ft})\end{array}$ & $\begin{array}{c}\text { Riv } \\
\text { De }\end{array}$ \\
\hline Left Bank & 0 & & \\
& 67 & 0.58 & 3 \\
& 121 & 0.63 & 1 \\
& 178 & 0.67 & 3 \\
& 230 & 0.63 & 6 \\
& 300 & 0.58 & 4 \\
& 331 & 0.58 & 5 \\
& 358 & 0.67 & 57 \\
& 377 & 0.75 & 7 \\
& 400 & 0.67 & 1 \\
Right Bank & 425 & 0.65 & 11.7 \\
& 445 & &
\end{tabular}

\begin{tabular}{|c|c|c|c|c|c|}
\hline \multirow[b]{2}{*}{ Iee Type } & \multicolumn{4}{|c|}{ Following Peaking@0915 hr 1/30/97 } & \multirow[b]{2}{*}{ Iee Type } \\
\hline & & $\begin{array}{c}\text { Station } \\
\text { (it) }\end{array}$ & $\begin{array}{c}\text { Ice } \\
\text { Thickness } \\
\text { (f) }\end{array}$ & $\begin{array}{c}\text { River } \\
\text { Depth } \\
\text { (ft) } \\
\end{array}$ & \\
\hline & Left Bank & 0 & & & \\
\hline shoet ice & & 67 & 0.65 & 4.3 & sheet ice \\
\hline$"$ & & 121 & 0.71 & 3.6 & $"$ \\
\hline " & & 178 & 0.73 & 2.3 & " \\
\hline " & & 230 & 0.69 & 1.3 & " \\
\hline sheet \& frazil pans & & 300 & 0.58 & 5.6 & $"$ \\
\hline " & & 331 & 0.75 & 6 & sheet \& frazil pans \\
\hline$"$ & & 358 & 0.60 & 4.6 & 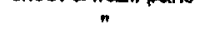 \\
\hline " & & 377 & 0.81 & 5.3 & $n$ \\
\hline " & & 400 & 0.81 & 12 & " \\
\hline " & & 425 & 0.69 & 12.2 & " \\
\hline & Right Bank & 445 & & & \\
\hline & & & 0.70 & 5.7 & \\
\hline
\end{tabular}

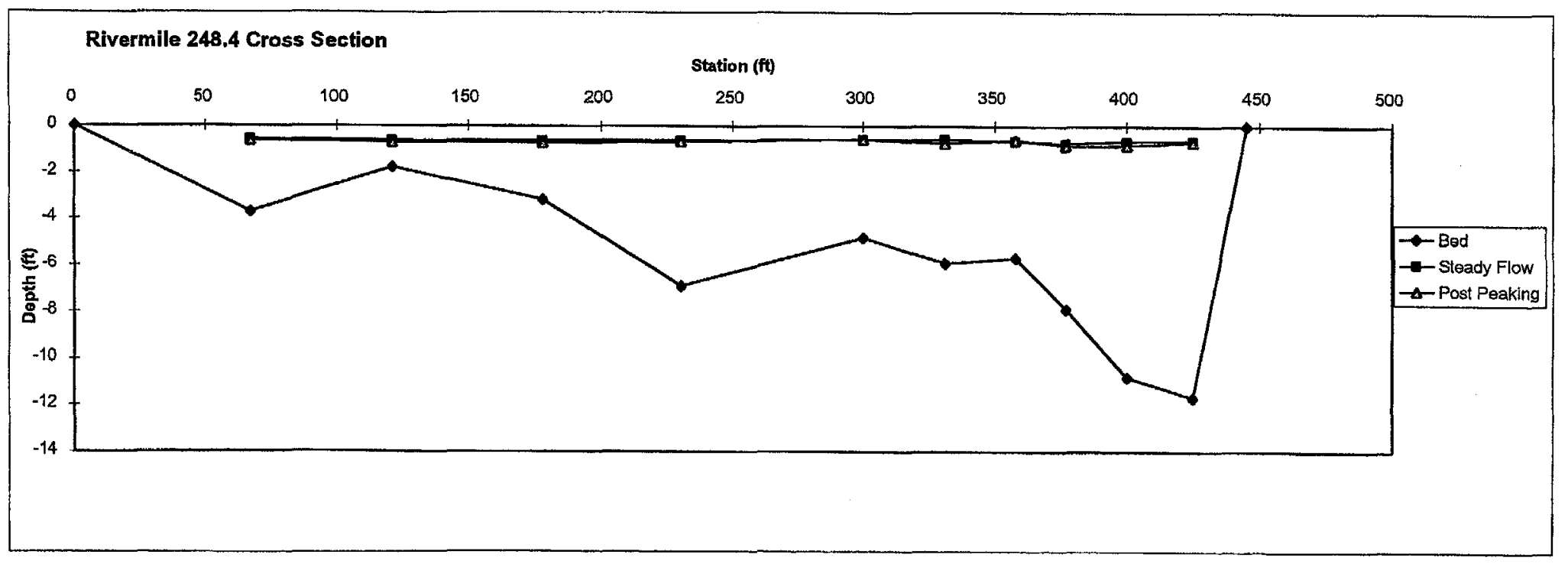


Location: RM 249.5 Abeam island, below Old Charlie Wash During Steady Flow Period @ 0930 hr 1/23/97

\begin{tabular}{|c|c|c|c|c|c|c|c|c|c|}
\hline & $\begin{array}{c}\text { Station } \\
\text { (ft) }\end{array}$ & $\begin{array}{c}\text { Ice } \\
\text { Thickness } \\
\text { (fi) }\end{array}$ & $\begin{array}{c}\text { River } \\
\text { Depth } \\
\text { (ft) } \\
\end{array}$ & Ice Type & & $\begin{array}{c}\text { Station } \\
\text { (II) }\end{array}$ & $\begin{array}{c}\text { Ice } \\
\text { Thickness } \\
\text { (fi) } \\
\end{array}$ & $\begin{array}{c}\text { River } \\
\text { Depth } \\
\text { (f) }\end{array}$ & Ice Type \\
\hline \multirow{9}{*}{ Left Bank } & 0 & & & & Left Bank & 0 & & & \\
\hline & 50 & 0.88 & 1.6 & sheat ice & & 25 & 0.65 & 4.3 & sheet ice \\
\hline & 100 & 0.75 & 1.8 & $"$ & & 50 & 0.71 & 3.6 & $"$ \\
\hline & 127 & 0.75 & 4.7 & $"$ & & 100 & 0.73 & 2.3 & " \\
\hline & 150 & 0.58 & 6.3 & $"$ & & 150 & 0.69 & 1.3 & $"$ \\
\hline & 180 & 0.63 & 4.9 & sheet \& frazil pans & & 200 & 0.58 & 5.6 & sheet \& frazil pans \\
\hline & 200 & 0.61 & 6.8 & $"$ & & 250 & 0.75 & 6 & " \\
\hline & 250 & 0.56 & 6.3 & " & & 300 & 0.60 & 4.6 & " \\
\hline & 300 & 0.70 & 5.3 & " & & 350 & 0.81 & 5.3 & " \\
\hline Right Bank & 350 & & & & Right Bank & 400 & & & \\
\hline Averages & & 0.68 & 4.7 & & & & 0.69 & 4.1 & \\
\hline
\end{tabular}

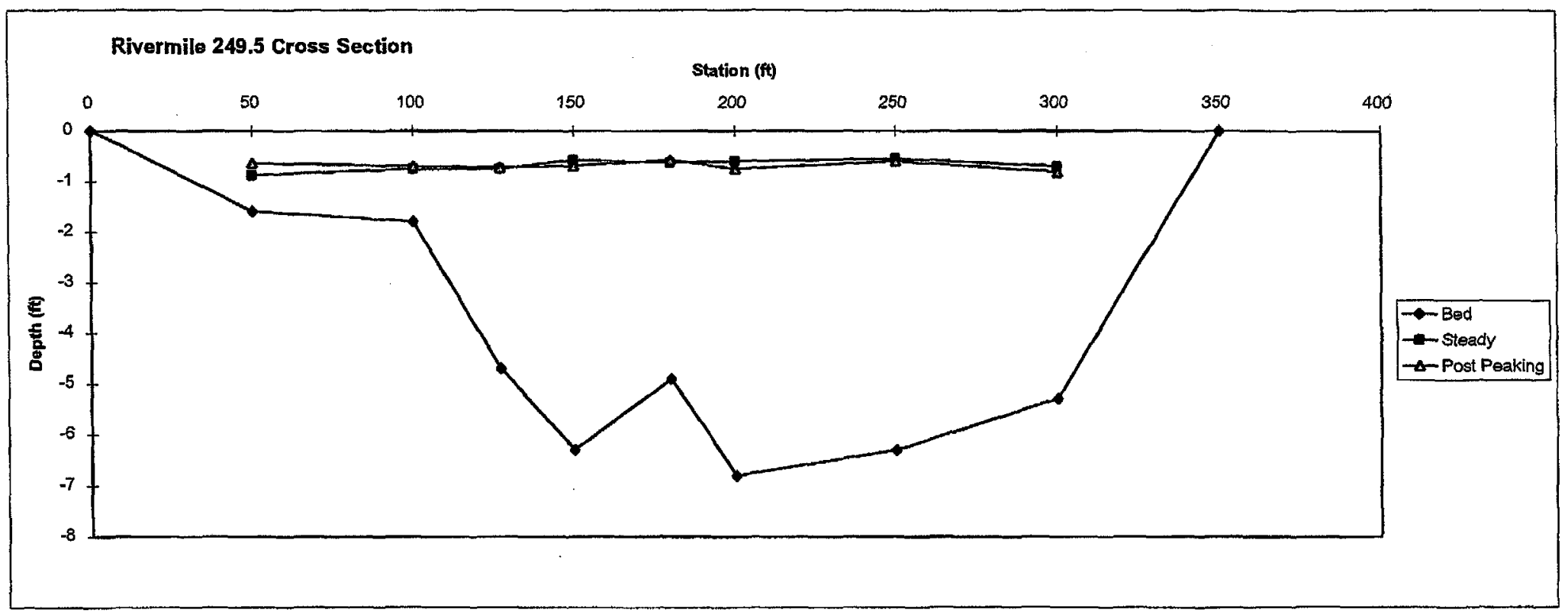


Location: RM 254.5 Downstream of small island, Ouray Wildlife Refuge, 1 mi. east of headquarters, near old hatchery During Steady Flow Period @ 1050 hr 1/23/97

Following Peaking @ 0950 hr 1/30/97

\begin{tabular}{|c|c|c|c|c|c|c|c|c|c|}
\hline & $\begin{array}{c}\text { Station } \\
\text { (ft) }\end{array}$ & $\begin{array}{c}\text { Ice } \\
\text { Thickness } \\
\text { (ft) } \\
\end{array}$ & $\begin{array}{c}\text { River } \\
\text { Depth } \\
\text { (t) }\end{array}$ & Ice Type & & $\begin{array}{c}\text { Station } \\
\text { (ft) }\end{array}$ & $\begin{array}{c}\text { Ice } \\
\text { Thickness } \\
\text { (ft) } \\
\end{array}$ & $\begin{array}{c}\text { River } \\
\text { Depth } \\
\text { (fi) } \\
\end{array}$ & Ice Type \\
\hline \multirow[t]{9}{*}{ Lefl Bank } & 0 & & & & Left Bank & 0 & & & \\
\hline & 60 & 0.67 & 6.7 & juxd. frazil pans & & 33 & 0.98 & 6.2 & sheet ice \\
\hline & 110 & 0.75 & 11.1 & " & & 58 & 0.96 & 4.4 & $"$ \\
\hline & 160 & 0.83 & 5.7 & " & & 108 & 0.79 & 11.6 & sheot ice \& fraz. pans \\
\hline & 210 & 1.13 & 4.4 & " & & 158 & 0.79 & 6.6 & $\pi$ \\
\hline & 260 & 0.67 & 4.5 & " & & 208 & 1.06 & 4.6 & $"$ \\
\hline & 310 & 0.66 & 5.3 & " & & 258 & 0.79 & 4.2 & $"$ \\
\hline & 360 & 0.71 & 4.4 & " & & 308 & 0.75 & 4.1 & " \\
\hline & 410 & 0.69 & 5 & " & & 358 & 0.71 & 4.6 & " \\
\hline \multirow[t]{3}{*}{ Right Bank } & 460 & & & & & 408 & 0.77 & 4.4 & " \\
\hline & & & & & & 433 & 0.75 & 5 & juxt. frazil pans \\
\hline & & & & & Right Bank & 458 & & & \\
\hline Averages & & 0.7 & & & & & 0.84 & 5.6 & \\
\hline
\end{tabular}

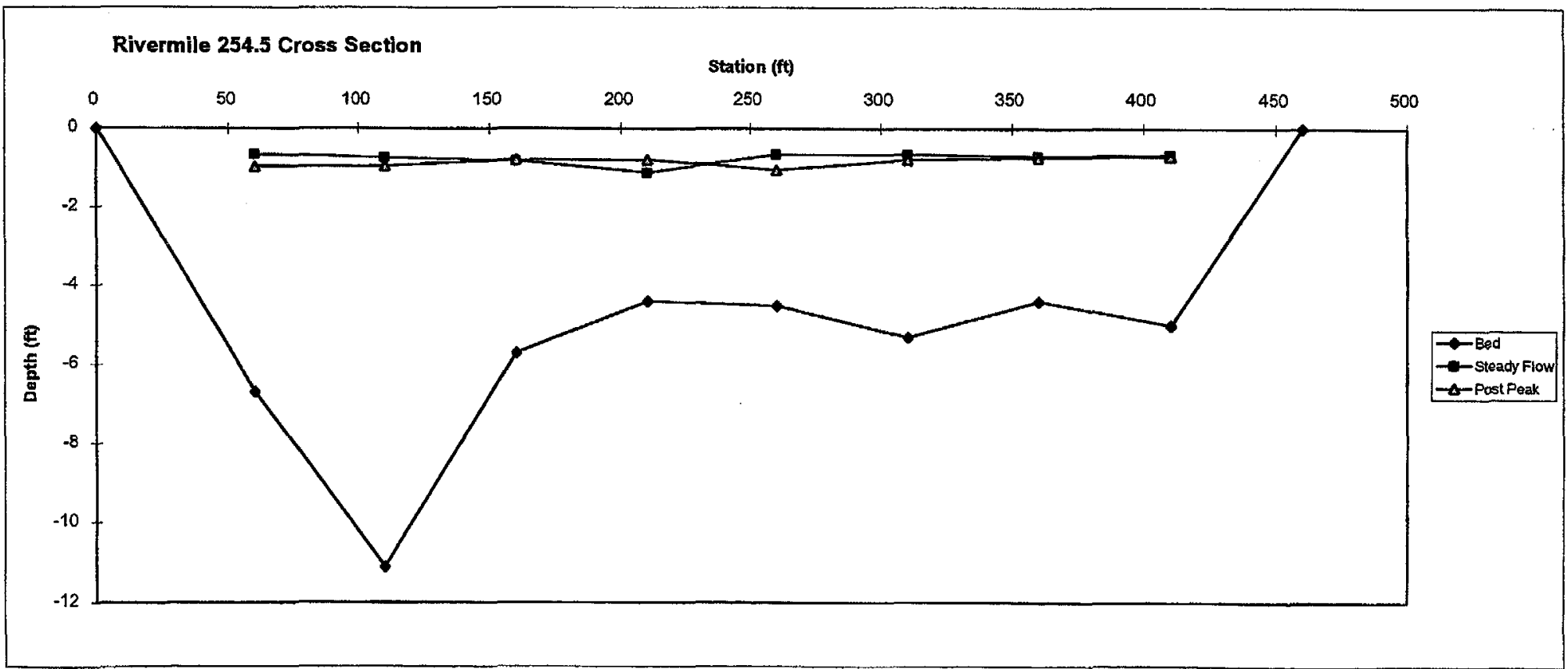


Location: RM 256.8 Ouray Wildlife Refuge

During Steady Flow Period @ 1145 hr 1/23/97

\begin{tabular}{|c|c|c|c|c|c|c|c|c|c|}
\hline & $\begin{array}{c}\text { Station } \\
\text { (fi) }\end{array}$ & $\begin{array}{c}\text { lce } \\
\text { Thickness } \\
\text { (ft) } \\
\end{array}$ & $\begin{array}{c}\text { River } \\
\text { Depth } \\
\text { (fi) }\end{array}$ & lee Type & & $\begin{array}{c}\text { Station } \\
\text { (fi) }\end{array}$ & $\begin{array}{c}\text { Ice } \\
\text { Thickness } \\
\text { (fi) }\end{array}$ & $\begin{array}{l}\text { River } \\
\text { Depth } \\
\text { (ft) }\end{array}$ & Ice Type \\
\hline \multirow{11}{*}{ Left Bank } & 0 & & & & Lefit Bank & $\begin{array}{r}0 \\
458\end{array}$ & & & \\
\hline & 50 & 0.54 & 1.8 & sheet ice & & $\begin{array}{r}458 \\
60\end{array}$ & 0.60 & & shetich \\
\hline & 100 & 0.54 & 2.2 & " & & 110 & 0.71 & $\begin{array}{l}1.8 \\
2.4\end{array}$ & sheerice \\
\hline & 150 & 0.63 & 3.4 & $"$ & & 160 & 0.67 & 2.8 & " \\
\hline & 200 & 0.63 & 3.2 & juxt. frazil pans & & 260 & 0.69 & 2.5 & " \\
\hline & 250 & 0.65 & 3.1 & $"$ & & 360 & 0.69 & 9.5 & sheet $\&$ pans \\
\hline & 300 & 0.65 & 3.6 & $"$ & & 460 & 0.79 & 7.8 & juxt. frazil pans \\
\hline & 350 & 0.67 & 9.2 & " & Right Bank & 510 & 0.67 & 8.8 & " \\
\hline & 400 & 0.67 & 6.6 & " & & 560 & & & \\
\hline & 450 & 0.79 & 7.8 & " & & & & & \\
\hline & 500 & 0.58 & 9.2 & $"$ & & & & & \\
\hline Right Bank & 550 & & & & & & & & \\
\hline Averages & & 0.63 & 5.0 & & & & 0.69 & 5.1 & \\
\hline
\end{tabular}

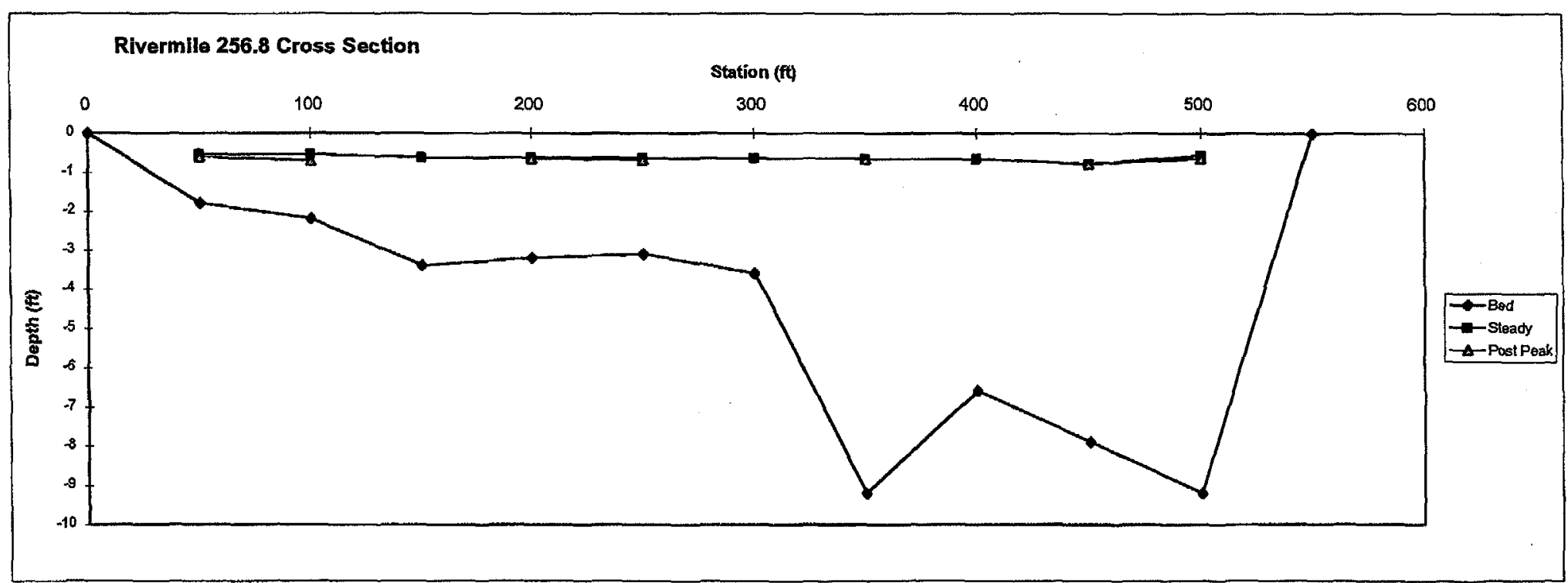


Location: RM 258.3 Ouray Wildlife Refuge

During Steady Flow Period @ 1145 hr 1/23/97

Following Peaking @ 0915 hr 1/30/97

\begin{tabular}{|c|c|c|c|c|c|c|c|c|c|}
\hline & $\begin{array}{c}\text { Station } \\
\text { (fi) }\end{array}$ & $\begin{array}{c}\text { lee } \\
\text { Thickness } \\
\text { (fi) } \\
\end{array}$ & $\begin{array}{c}\text { River } \\
\text { Depth } \\
\text { (ft) } \\
\end{array}$ & Ice Type & & $\begin{array}{c}\text { Station } \\
\text { (A) }\end{array}$ & $\begin{array}{c}\text { Ice } \\
\text { Thickness } \\
\text { (ft) }\end{array}$ & $\begin{array}{l}\text { River } \\
\text { Depth } \\
\text { (ft) }\end{array}$ & Ice Type \\
\hline \multirow[t]{9}{*}{ Left Bank } & 0 & & & & Left Bank & 0 & & & \\
\hline & 43 & 0.67 & 2.7 & sheet ice & & 75 & 0.73 & 2.0 & sheet ice \\
\hline & 143 & 0.96 & 1.3 & " & & 125 & 0.96 & 1.1 & $"$ \\
\hline & 243 & 0.75 & 1.6 & $"$ & & 225 & 0.79 & 1.1 & " \\
\hline & 343 & 0.54 & 4.3 & " & & 325 & 0.65 & 3.8 & $n$ \\
\hline & 443 & 0.69 & 3.4 & $"$ & & 425 & 0.73 & 3.1 & shoet \& pans \\
\hline & 543 & 0.67 & 3.5 & sheet \& fraz. pans & & 525 & 0.75 & 3.3 & " \\
\hline & 643 & 0.73 & 5.4 & $\omega$ & & 625 & 0.77 & 5.3 & n \\
\hline & 693 & 0.67 & 12.3 & juxt. frazil pans & & 675 & 0.75 & 7.1 & $"$ \\
\hline Right Bank & 743 & & & & Right Bank & 725 & & & \\
\hline Averages & & 0.71 & 4.3 & & & & 0.77 & 3.4 & \\
\hline
\end{tabular}

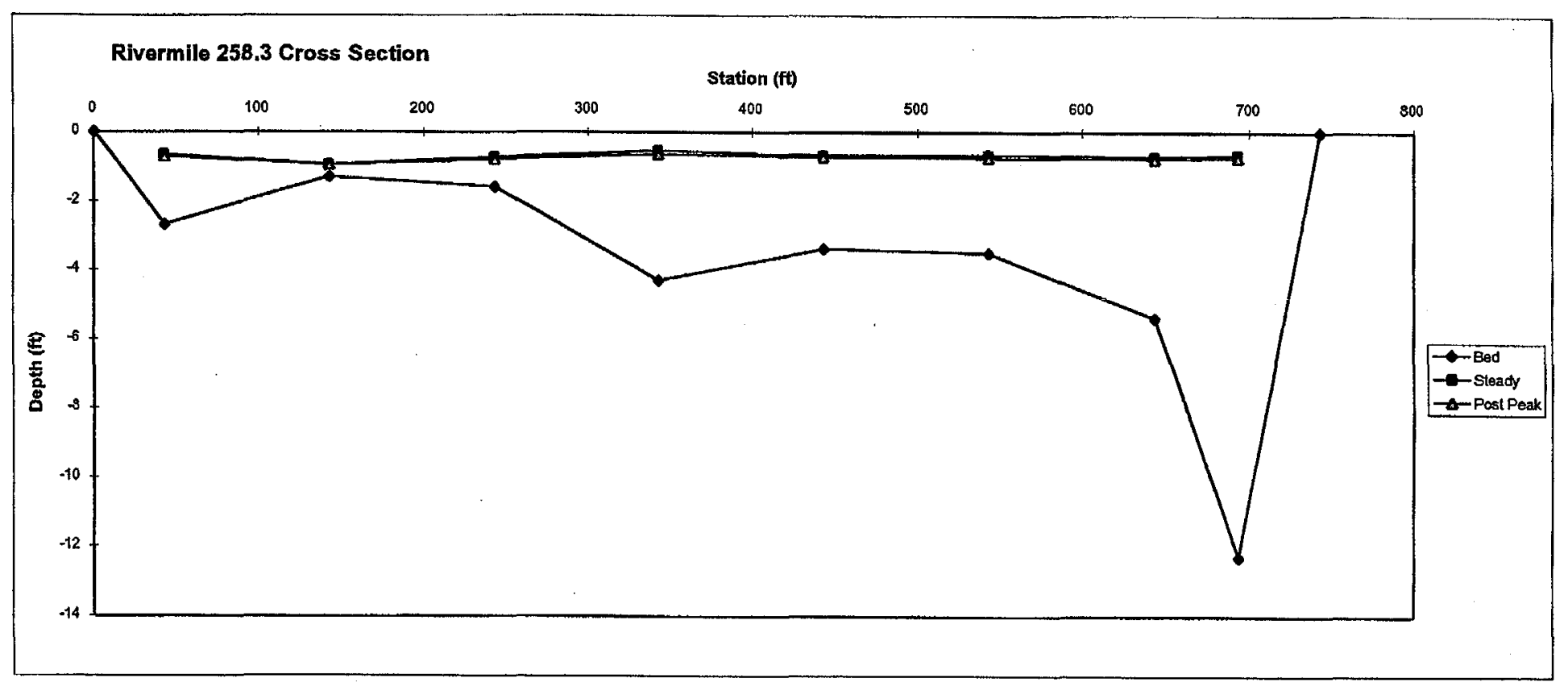


Location: RM 262 Ouray Wildlife Refuge, $100 \mathrm{ft}$ upstream of intakes to new hatchery. During Steady Flow Period @ 1330 hr 1/23/97

Following Peaking @ 1010 hr 1/30/97

\begin{tabular}{|c|c|c|c|c|c|c|c|c|c|}
\hline & $\begin{array}{c}\text { Station } \\
\text { (fi) }\end{array}$ & $\begin{array}{c}\text { lee } \\
\text { Thickness } \\
\text { (ft) }\end{array}$ & $\begin{array}{c}\text { River } \\
\text { Depth } \\
\text { (ft) } \\
\end{array}$ & Ice Type & & $\begin{array}{c}\text { Station } \\
\text { (fi) }\end{array}$ & $\begin{array}{c}\text { Ice } \\
\text { Thickness } \\
\text { (ft) }\end{array}$ & $\begin{array}{l}\text { River } \\
\text { Depth } \\
\text { (ft) }\end{array}$ & Ice Type \\
\hline Edge of Bar & 0 & & & & Left Bank & 0 & & & \\
\hline & 30 & 0.71 & 1.5 & sheet ice & & 30 & 0.75 & 1.2 & sheet ics \\
\hline & 80 & 0.50 & 1.4 & " & & 80 & 0.69 & 1.2 & 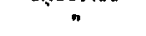 \\
\hline & 130 & 0.63 & 4.5 & " & & 130 & 0.65 & 4.5 & $"$ \\
\hline & 180 & 0.73 & 5,0 & edge of sheet & & 180 & 0.67 & 4.7 & sheet \& pans \\
\hline & 230 & 0.73 & 10.4 & frazil pans & & 260 & 0.77 & 8.5 & frazil pans \\
\hline & 280 & 0.60 & 6.6 & $"$ & & 280 & 0.67 & 7.8 & $"$ \\
\hline Right Bank & 330 & & & & Right Bank & 330 & & & \\
\hline Averages & & 0.65 & 4.9 & & & & 0.70 & 4.7 & \\
\hline
\end{tabular}

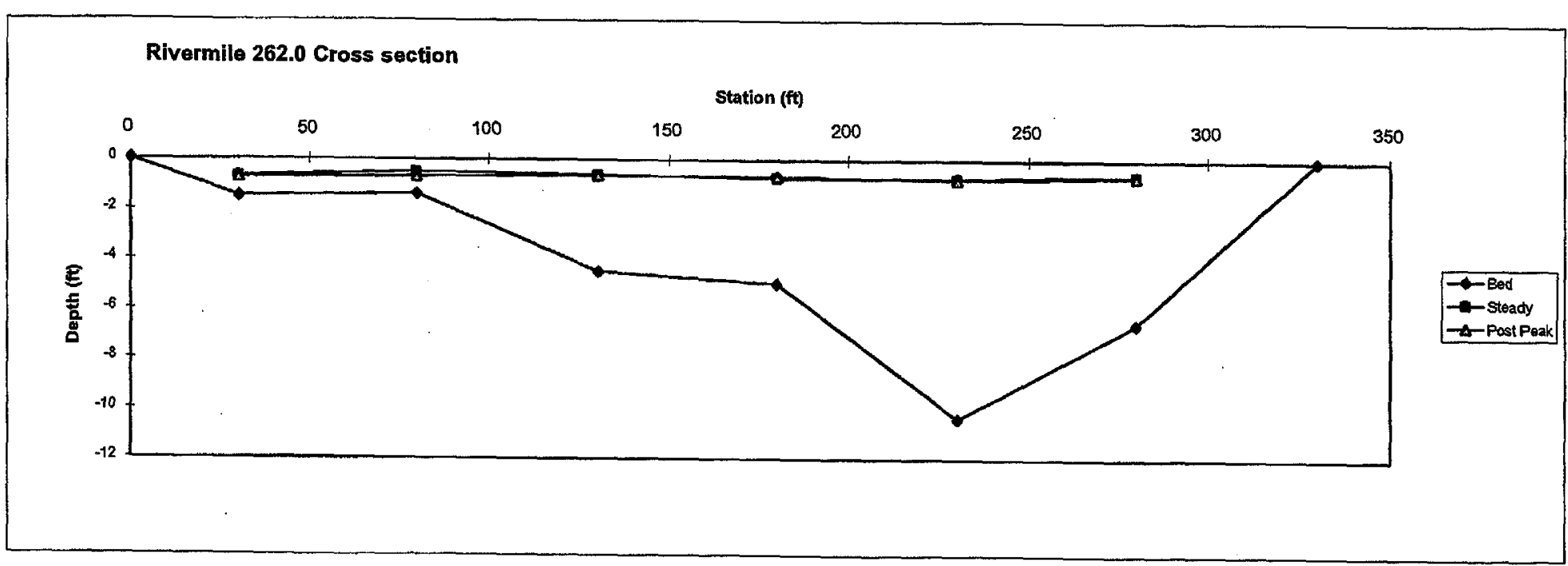


Location: RM 265.4 Brennan Bottom

During Steady Flow Period @ 1450 hr 1/23/97

Following Peaking @ 1600 hr 1/29/97

\begin{tabular}{|c|c|c|c|c|c|c|c|c|c|}
\hline & $\begin{array}{c}\text { Station } \\
(\mathrm{ft})\end{array}$ & $\begin{array}{c}\text { Ice } \\
\text { Thickness } \\
\text { (ft) } \\
\end{array}$ & $\begin{array}{l}\text { River } \\
\text { Depth } \\
\text { (ft) } \\
\end{array}$ & Ice Type & & $\begin{array}{l}\text { Station } \\
\text { (ft) }\end{array}$ & $\begin{array}{c}\text { lee } \\
\text { Thiekness } \\
\text { (ft) } \\
\end{array}$ & $\begin{array}{c}\text { River } \\
\text { Depth } \\
\text { (ft) }\end{array}$ & Ice Type \\
\hline \multirow[t]{6}{*}{ Left Bank } & 0 & & & & Left Bank & 0 & & & \\
\hline & 70 & 0.75 & 2.9 & frazil pans & & 25 & 0.71 & 3.2 & sheet ice \\
\hline & 170 & 0.65 & 7.7 & " & & 75 & 0.79 & 3.2 & " \\
\hline & 270 & 0.67 & 5.1 & $"$ & & 175 & 0.77 & 7.7 & sheet \& pans \\
\hline & 370 & 0.60 & 1.9 & $"$ & & 275 & 0.77 & 4.8 & $"$ \\
\hline & 460 & 0.58 & 2.2 & sheet ice & & 375 & 0.73 & 1.6 & sheet ice \\
\hline \multirow{3}{*}{$\begin{array}{l}\text { R. Edge Bar } \\
\text { L. Edge Bar }\end{array}$} & 475 & & & Bar & & 425 & 0.56 & 2.6 & $"$ \\
\hline & 581 & & & Bar & & 475 & & & Bar \\
\hline & 670 & 0.67 & 3.2 & Sheet ice & & 580 & & & Bar \\
\hline \multirow[t]{5}{*}{ Right Bank } & 770 & & & & & 614 & 0.54 & 2.0 & sheet ice \\
\hline & & & & & & 664 & 0.63 & 4 & 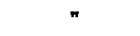 \\
\hline & & & & & & 714 & 0.42 & 2.6 & $n$ \\
\hline & & & & & Right Bank & 764 & & & \\
\hline & Averages & 0.65 & 3.8 & & & & 0.66 & 3.5 & \\
\hline
\end{tabular}

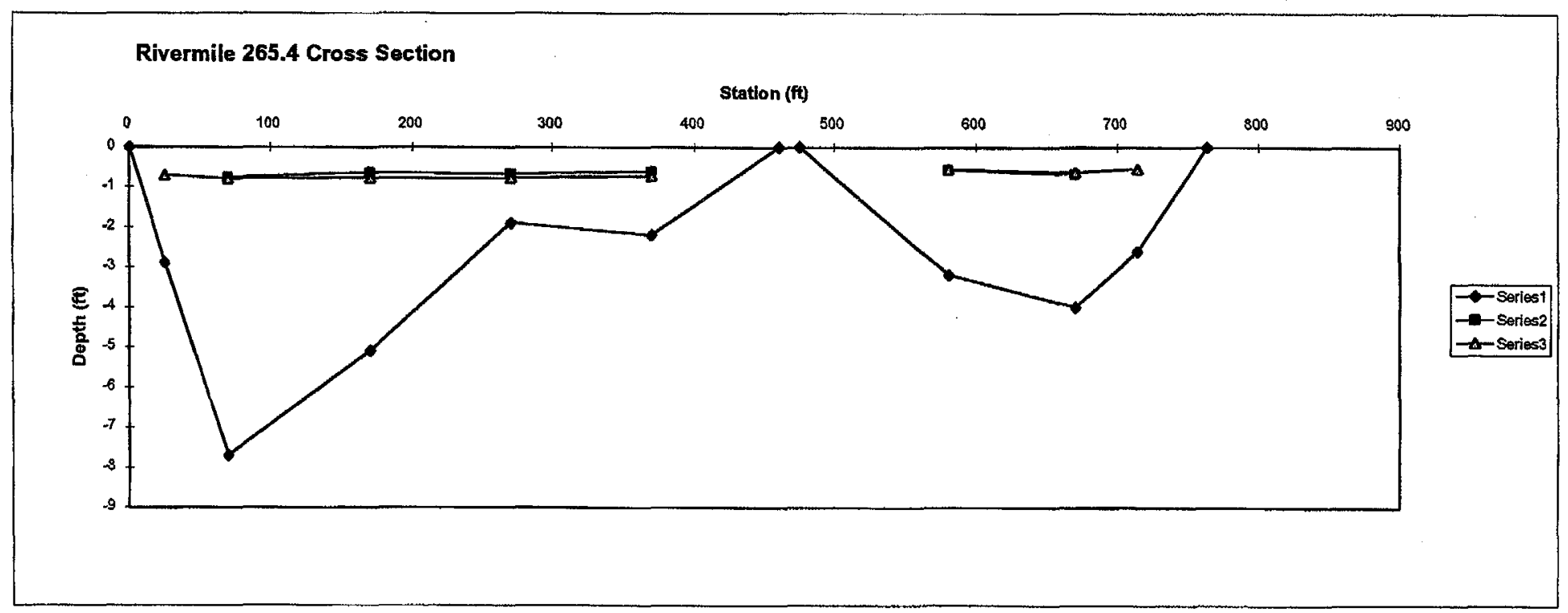


Location: RM 276.5 Downstream end of Horseshoe Bend

During Steady Flow Period @ 1000 hr 1/24/97

Following Peaking @ 1320 hr 1/29/97

\begin{tabular}{|c|c|c|c|c|c|c|c|c|c|}
\hline & $\begin{array}{c}\text { Station } \\
\text { (fi) }\end{array}$ & $\begin{array}{c}\text { Ife } \\
\text { Thickness } \\
\text { (ii) } \\
\end{array}$ & $\begin{array}{c}\text { River } \\
\text { Depth } \\
\text { (ft) }\end{array}$ & lee Type & & $\begin{array}{c}\text { Station } \\
\text { (ft) }\end{array}$ & $\begin{array}{c}\text { 1ce } \\
\text { Thickness } \\
\text { (ft) } \\
\end{array}$ & $\begin{array}{c}\text { River } \\
\text { Depth } \\
\text { (ft) }\end{array}$ & Ice Type \\
\hline \multirow{15}{*}{ Left Bank } & 0 & & & & Left Bank & 0 & & & \\
\hline & 50 & 0.71 & 5.6 & frazil pans & & 20 & 0.58 & 6.5 & frazil pans \\
\hline & 100 & 0.63 & 4.3 & " & & 70 & 0.48 & 5.9 & " \\
\hline & 150 & 0.46 & 2.5 & $"$ & & 170 & 0.60 & 3.4 & $"$ \\
\hline & 200 & 0.58 & 3.4 & $"$ & & 270 & 0.54 & 2.5 & sheet \& fraz pans \\
\hline & 250 & 0.88 & 4.5 & $"$ & & 370 & 0.71 & 3.8 & $"$ \\
\hline & 300 & 0.69 & 3.8 & " & & 470 & 0.67 & 3.9 & juxt. frazil pans \\
\hline & 350 & 1.42 & 2.2 & " & & 570 & 0.52 & 3.9 & " \\
\hline & 400 & 0.50 & 4.5 & n & & 670 & 0.71 & 4 & " \\
\hline & 450 & 0.54 & 4.1 & $"$ & & 720 & 0.83 & 12.3 & " \\
\hline & 500 & 0.69 & 4.9 & " & Right Bank & 770 & & & \\
\hline & 550 & 0.50 & 4.4 & $"$ & & & & & \\
\hline & 600 & 0.60 & 4.4 & " & & & & & \\
\hline & 650 & 0.65 & 4.1 & " & & & & & \\
\hline & 700 & 0.63 & 11.5 & & & & & & \\
\hline Right Bank & 750 & & & & & & & & \\
\hline Averages & & 0.68 & 4.05 & & & & 0.63 & 5.13 & \\
\hline
\end{tabular}

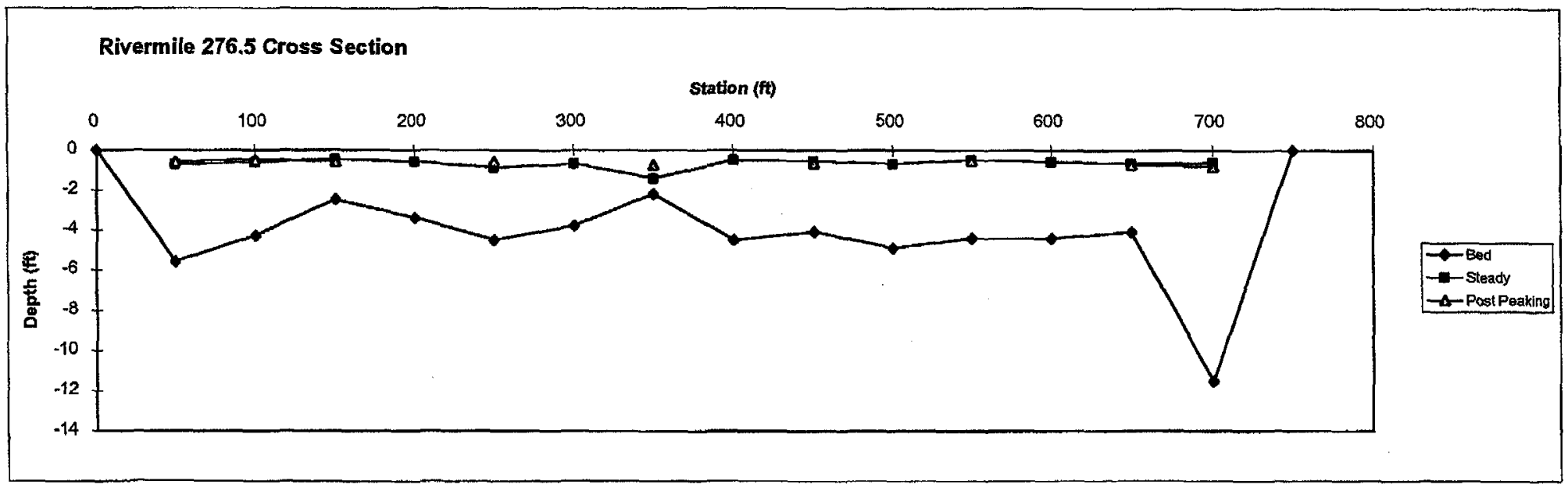


Location: RM 278 South Part of Horseshoe Bend

During Steady Flow Period @ 1130 hr 1/24/97

Following Peaking @ 1320 hr 1/29/97

\begin{tabular}{|c|c|c|c|c|c|c|c|c|c|}
\hline & $\begin{array}{c}\text { Station } \\
\text { (f) }\end{array}$ & $\begin{array}{c}\text { Ice } \\
\text { Thickness } \\
\text { (ft) } \\
\end{array}$ & $\begin{array}{c}\text { River } \\
\text { Depth } \\
\text { (ft) } \\
\end{array}$ & Ice Type & & $\begin{array}{c}\text { Station } \\
\text { (ft) }\end{array}$ & $\begin{array}{c}\text { Ice } \\
\text { Thickness } \\
\text { (f) }\end{array}$ & $\begin{array}{l}\text { River } \\
\text { Depth } \\
\text { (tt) }\end{array}$ & Ice Type \\
\hline \multirow[t]{10}{*}{ Left Bank } & 0 & & & & Left Bank & 0 & & & \\
\hline & 50 & 0.50 & 7.8 & frazil pans & & 65 & 0.71 & 7.5 & frazil pans \\
\hline & 100 & 0.63 & 5.1 & $"$ & & 165 & 0.65 & 5.4 & $n$ \\
\hline & 150 & 0.69 & 5.4 & " & & 265 & 0.77 & 4.7 & sheet \& fraz. pans \\
\hline & 200 & 1.00 & 6 & frazil pans \& sheet & & 305 & 0.69 & 3.5 & " \\
\hline & 250 & 0.69 & 4.9 & " & & 365 & & & " \\
\hline & 300 & 0.63 & 3.8 & frazil pans & & 610 & & & " \\
\hline & 400 & 0.00 & 0 & " & & 645 & 0.77 & 2.7 & sheet ice \\
\hline & 685 & 0.75 & 3.2 & shoot ice & & 695 & 0.65 & 3.4 & " \\
\hline & 735 & 0.60 & 2.1 & " & Right Bank & 745 & & & \\
\hline Right Bank & 785 & & & " & & & & & \\
\hline Averages & & 0.61 & 4.26 & & & & 0.70 & 4.53 & \\
\hline
\end{tabular}

官

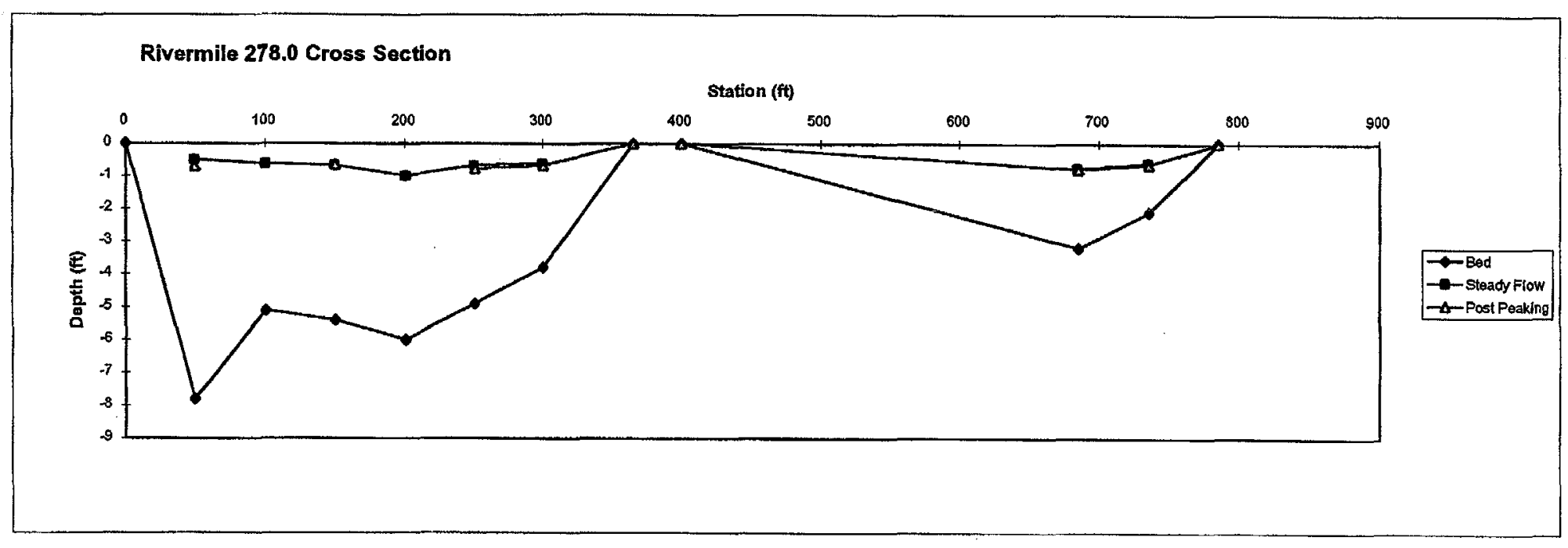


Location: RM 279 Mid-Horseshoe Bend

During Steady Flow Period @ 1245 hr 1/24/97

Following Peaking @ 1320 hr 1/29/97

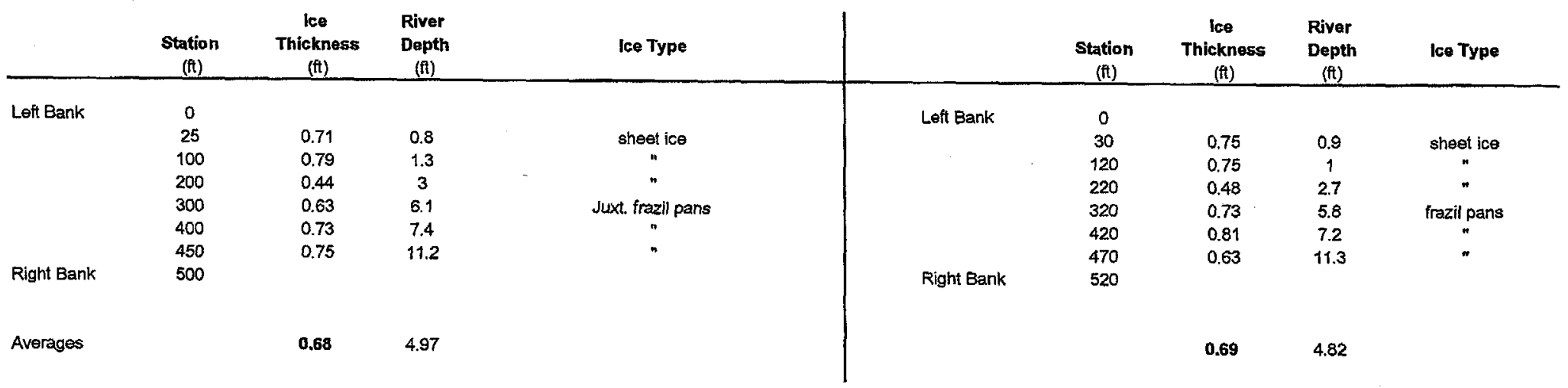

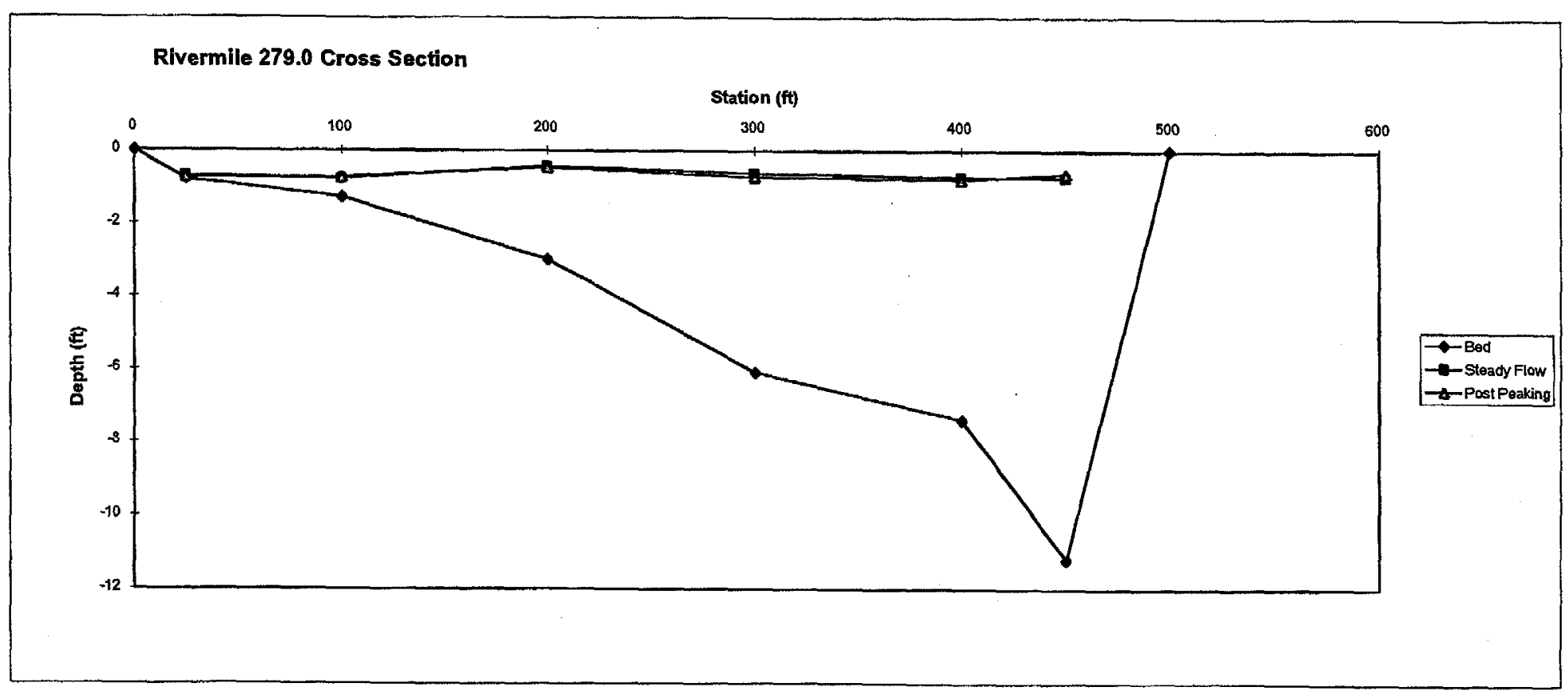


Location: RM 290.40 .5 miles upstream of Bonanza Bridge

During Steady Flow Period @ 1400 hr 1/24/97

Following Peaking@1015 hr 1/29/97

\begin{tabular}{|c|c|c|c|c|c|c|c|c|c|}
\hline & $\begin{array}{c}\text { Station } \\
\text { (fi) }\end{array}$ & $\begin{array}{c}\text { Ice } \\
\text { Thickness } \\
\text { (f) }\end{array}$ & $\begin{array}{c}\text { River } \\
\text { Depth } \\
\text { (fi) }\end{array}$ & Ice Type & & $\begin{array}{c}\text { Station } \\
\text { (ft) }\end{array}$ & $\begin{array}{c}\begin{array}{c}\text { lce } \\
\text { Thickness } \\
\text { (ft). }\end{array} \\
\end{array}$ & $\begin{array}{l}\text { River } \\
\text { Depth } \\
\text { (fi) }\end{array}$ & Ice Type \\
\hline \multirow[t]{13}{*}{ Left Bank } & 0 & & & & Left Bank & 0 & & & \\
\hline & 50 & 0.38 & 3.6 & sheet ice & & 50 & 0.38 & 3.6 & sheet ice \\
\hline & 100 & 0.31 & 3.1 & " & & 100 & 0.35 & 3.2 & " \\
\hline & 150 & 0.50 & 1.5 & " & & 150 & 0.58 & 1.8 & $"$ \\
\hline & 200 & & 0 & " & & 175 & & & " \\
\hline & 465 & & 0 & " & & 355 & & & $"$ \\
\hline & 515 & 0.60 & 2.5 & $n$ & & 405 & 0.63 & 2.8 &. \\
\hline & 565 & 0.67 & 2.5 & " & & 455 & 0.50 & 2.5 & frazil pans \\
\hline & 615 & 0.65 & 2.9 & $"$ & & 555 & 0.73 & 4.3 & " \\
\hline & 665 & 0.73 & 3.2 & pans \& sheet & & 655 & 0.85 & 8.7 & pans \& sheo \\
\hline & 715 & 0.71 & 4.6 & 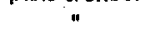 & & 705 & 0.88 & 9.8 & shet ice \\
\hline & 765 & 0.77 & 8.1 & $"$ & Right Bank & 870 & & & \\
\hline & 815 & 0.71 & 9.5 & " & & & & & \\
\hline Right Bank & 870 & & & & & & & & \\
\hline Averages & & 0.57 & 2.1 & & & & 0.61 & 4.6 & \\
\hline
\end{tabular}

官

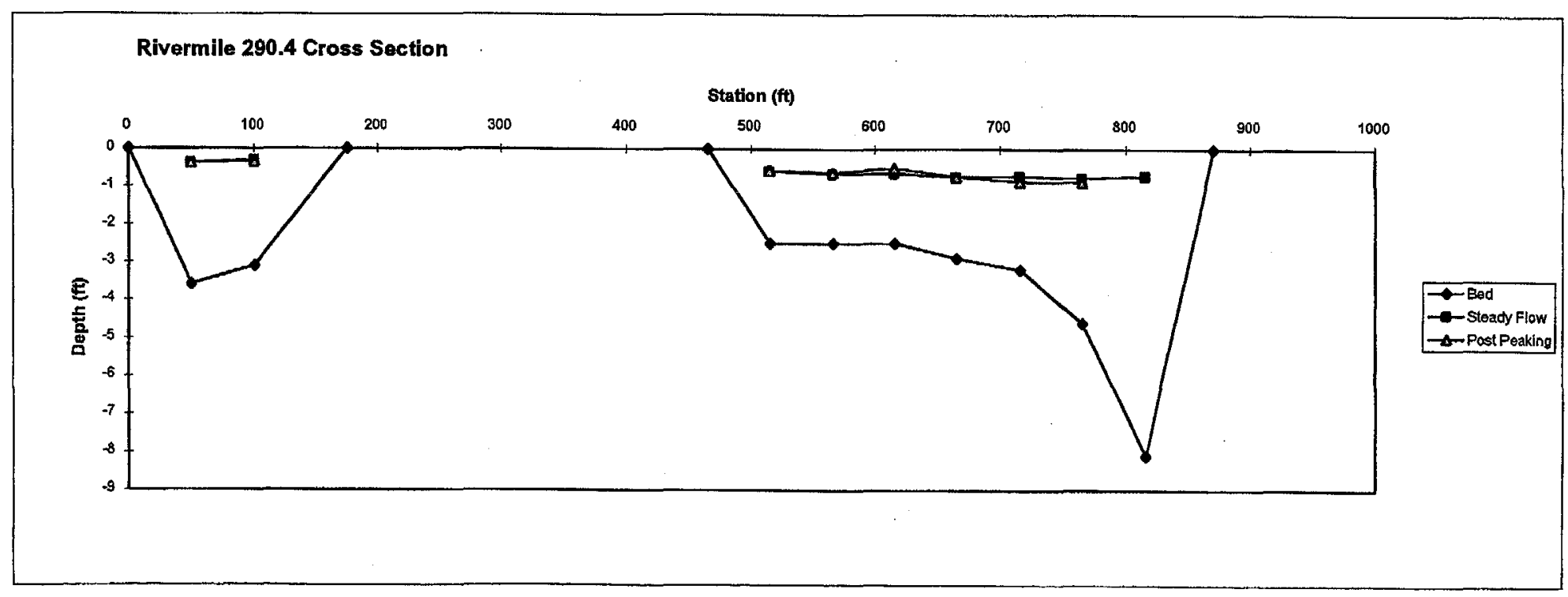


Location: RM 294 Walker Hollow

During Steady Flow Period @ 1500 hr 1/24/97

Following Peaking @ 1400 hr 1/29/97

\begin{tabular}{|c|c|c|c|c|c|c|c|c|c|}
\hline & $\begin{array}{l}\text { Station } \\
\text { (it) }\end{array}$ & $\begin{array}{c}\text { Ice } \\
\text { Thickness } \\
\text { (ft) } \\
\end{array}$ & $\begin{array}{c}\text { River } \\
\text { Depth } \\
\text { (ft) }\end{array}$ & Ice Type & & $\begin{array}{c}\text { Station } \\
\text { (it) }\end{array}$ & $\begin{array}{c}\text { lee } \\
\text { Thickness } \\
\text { (ft) } \\
\end{array}$ & $\begin{array}{c}\text { River } \\
\text { Depth } \\
\text { (ft) }\end{array}$ & Ice Type \\
\hline \multirow[t]{9}{*}{ Left Bank } & 0 & & & & Left Bank & 0 & & & \\
\hline & 50 & 0.60 & 2.8 & sheet ice & & 25 & 0.79 & 3.9 & sheet ice \\
\hline & 100 & 0.56 & 1.4 & $"$ & & 50 & 0.71 & 3.2 & $"$ \\
\hline & 200 & 0.63 & 5.5 & sheet \& frazil pans & & 100 & 0.71 & 1.6 & juxt. frazil pans \\
\hline & 300 & 0.71 & 5.0 & $"$ & & 200 & 0.71 & 5.4 & $"$ \\
\hline & 400 & 0.60 & 5.0 & " & & 300 & 0.90 & 5.7 & sheet \& frazil pans \\
\hline & 500 & 0.83 & 5.7 & " & & 400 & 0.79 & 4.9 & juxt. frazil pans \\
\hline & 600 & 0.69 & 3.7 & sheet ice & & 500 & 0.88 & 6.3 & W/ frazil slush beneath \\
\hline & 650 & 0.56 & 4.7 & $n$ & & 600 & 0.69 & 3.6 & sheet ice \\
\hline \multirow[t]{3}{*}{ Right Bank } & 712 & & & & & 675 & 0.63 & 3.8 & " \\
\hline & & & & & & 700 & 0.71 & 1.0 & \\
\hline & & & & & Right Bank & 715 & & & \\
\hline Averages & & 0.65 & 4.2 & & & & 0.75 & 3.9 & \\
\hline
\end{tabular}

$\stackrel{\dot{\omega}}{\dot{\psi}}$

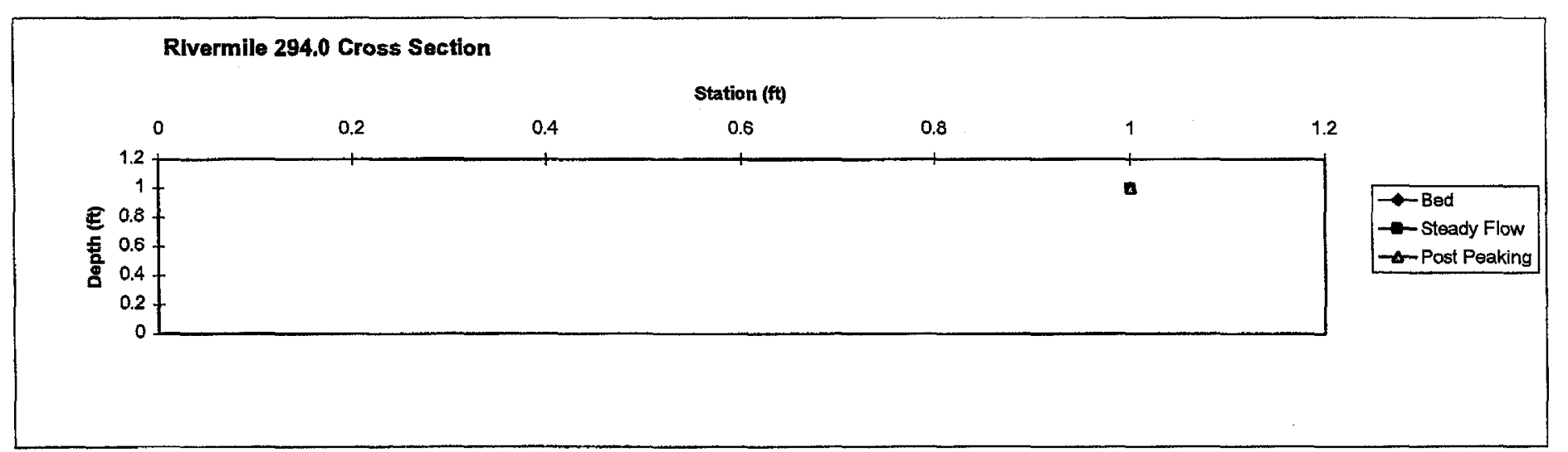


Location: RM $301.34000 \mathrm{ft}$ downstream of Jensen Bridge

During Steady Flow Period @ 1600 hr 1/24/97

\begin{tabular}{|c|c|c|c|c|c|c|c|c|c|}
\hline & $\begin{array}{c}\text { Station } \\
\text { (fi) }\end{array}$ & $\begin{array}{c}\text { Ice } \\
\text { Thickness } \\
\text { (fi) }\end{array}$ & $\begin{array}{c}\text { River } \\
\text { Depth } \\
\text { (ft) } \\
\end{array}$ & Ice Type & & $\begin{array}{c}\text { Station } \\
\text { (it) }\end{array}$ & $\begin{array}{c}\text { Ice } \\
\text { Thickness } \\
\text { (t) }\end{array}$ & $\begin{array}{c}\text { River } \\
\text { Depth } \\
\text { (ft) }\end{array}$ & Ice Type \\
\hline \multicolumn{8}{|l|}{ Left Bank } & & \\
\hline & 25 & 0.63 & 9.0 & Juxt. frazil pans & & 25 & 0.79 & 39 & Juxt frazil pans \\
\hline & 50 & 0.58 & 7.7 & " & & 50 & 0.71 & 3.2 & " \\
\hline & 75 & 0.67 & 7.1 & " & & 100 & 0.71 & 1.6 & " \\
\hline & 100 & 0.67 & 6.3 & " & & 150 & 0.71 & 5.4 & " \\
\hline & 200 & 0.67 & 3.7 & " & & 200 & 0.90 & 5.7 & " \\
\hline & 300 & 0.65 & 8.5 & $"$ & & 250 & 0.79 & 4.9 & n \\
\hline & 325 & 0.71 & 7.0 & " & & 300 & 0.88 & 6.3 & n \\
\hline \multirow[t]{2}{*}{ Right Bank } & 357 & & & & & 350 & 0.69 & 3.6 & \\
\hline & & & & & Right Bank & 368 & & & \\
\hline \multicolumn{10}{|l|}{ Averages } \\
\hline & & 0.65 & 7.0 & & & & 0.77 & 4.3 & \\
\hline
\end{tabular}

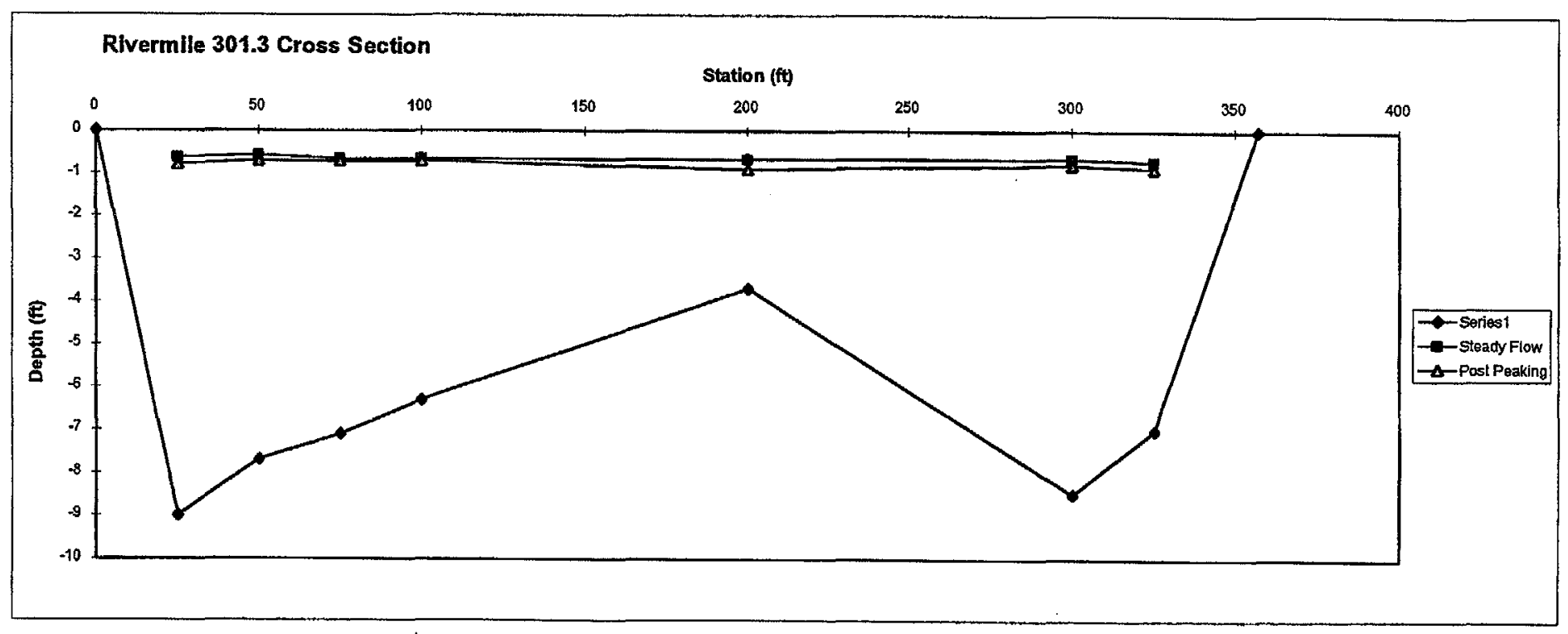


Location: RM $302.22000 \mathrm{ft}$ upstream of Jensen Bridge During Steady Flow Period @ $1430 \mathrm{hr}$ 1/24/97

Following Peaking @ 1230 hr 1/29/97

\begin{tabular}{|c|c|c|c|c|c|c|c|c|c|}
\hline & $\begin{array}{c}\text { Station } \\
\text { (it) }\end{array}$ & $\begin{array}{c}\text { Ire } \\
\text { Thickness } \\
\text { (ft) }\end{array}$ & $\begin{array}{l}\text { River } \\
\text { Depth } \\
\text { (ft) }\end{array}$ & Ice Type & & $\begin{array}{c}\text { Station } \\
\text { (f) }\end{array}$ & $\begin{array}{c}\text { Ice } \\
\text { Thickness } \\
\text { (fi) }\end{array}$ & $\begin{array}{l}\text { River } \\
\text { Depth } \\
\text { (ft) }\end{array}$ & lee Type \\
\hline \multirow{7}{*}{ Left Bank } & 0 & & & & Left Bank & 0 & & & \\
\hline & 25 & 0.58 & 2.5 & Juxt. frazil pans & & 25 & 0.83 & 2.6 & Juxt. frazil pans \\
\hline & 50 & 0.67 & 4.0 & " & & 50 & 0.50 & 4.8 & 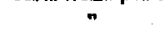 \\
\hline & 75 & 0.79 & 6.2 & * & & 100 & 0.67 & 7.2 & $"$ \\
\hline & 100 & 0.75 & 8.8 & sheet ice & & 150 & 0.75 & 12.2 & sheet ice \\
\hline & 150 & 0.73 & 10.2 & $n$ & & 200 & 0.69 & 9.2 & n \\
\hline & 200 & 0.71 & 12.0 & " & Rlight Bank & 233 & & & \\
\hline \multirow[t]{3}{*}{ Right Bank } & 233 & & & & & & & & \\
\hline & & & & & & & & & \\
\hline & & 0.71 & 7.3 & & & & 0.69 & 7.2 & \\
\hline
\end{tabular}

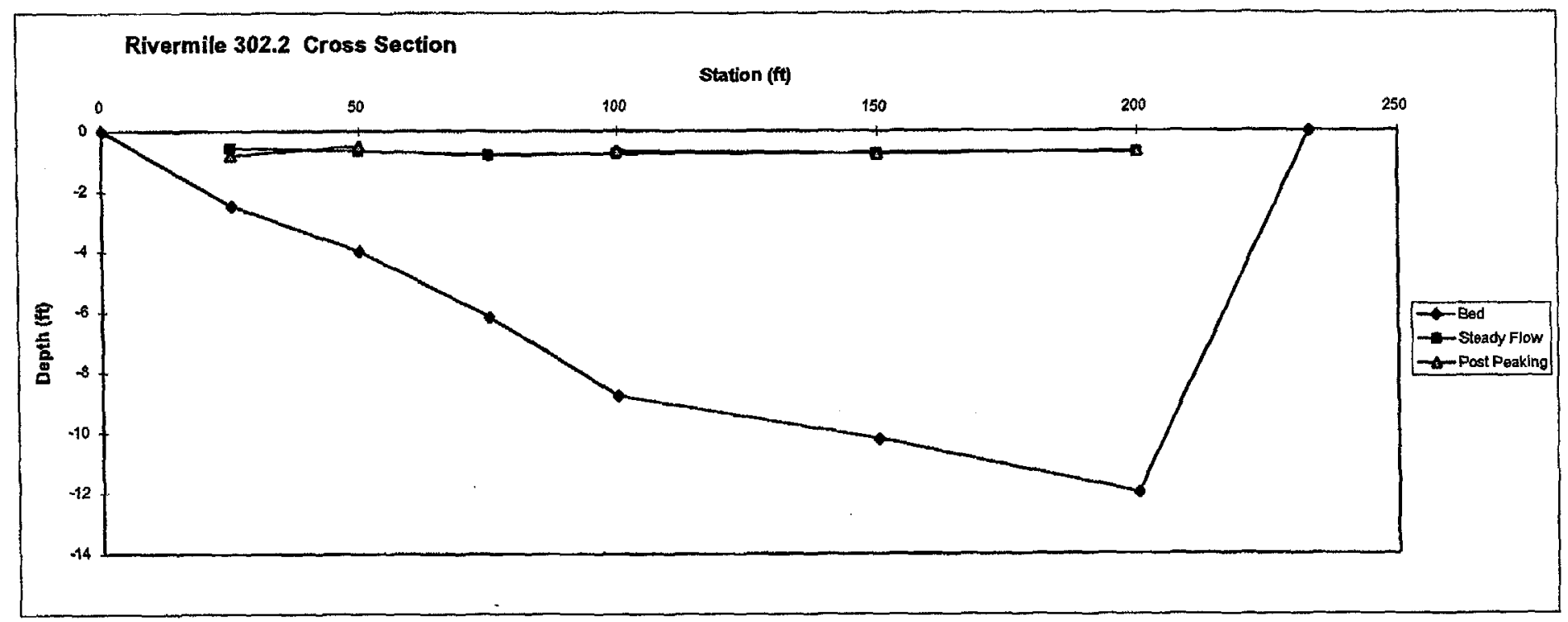


Location: RM 307 Downstream end of bend 1/4 mile upstream of Monument boundary

During Steady Flow Period @ 1220 hr 1/24/97

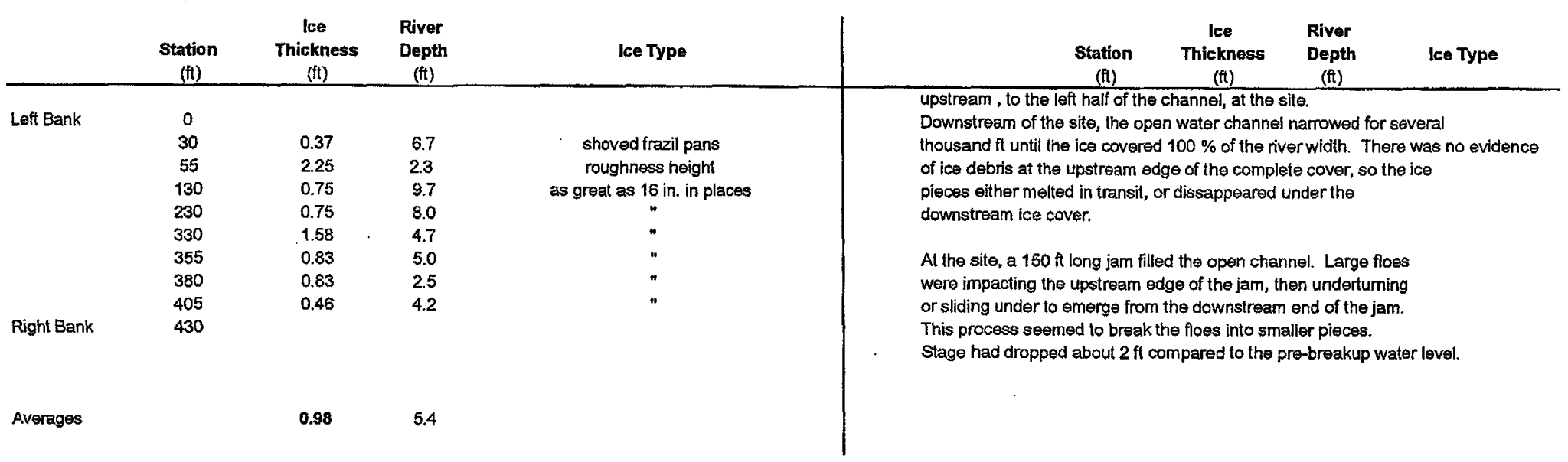

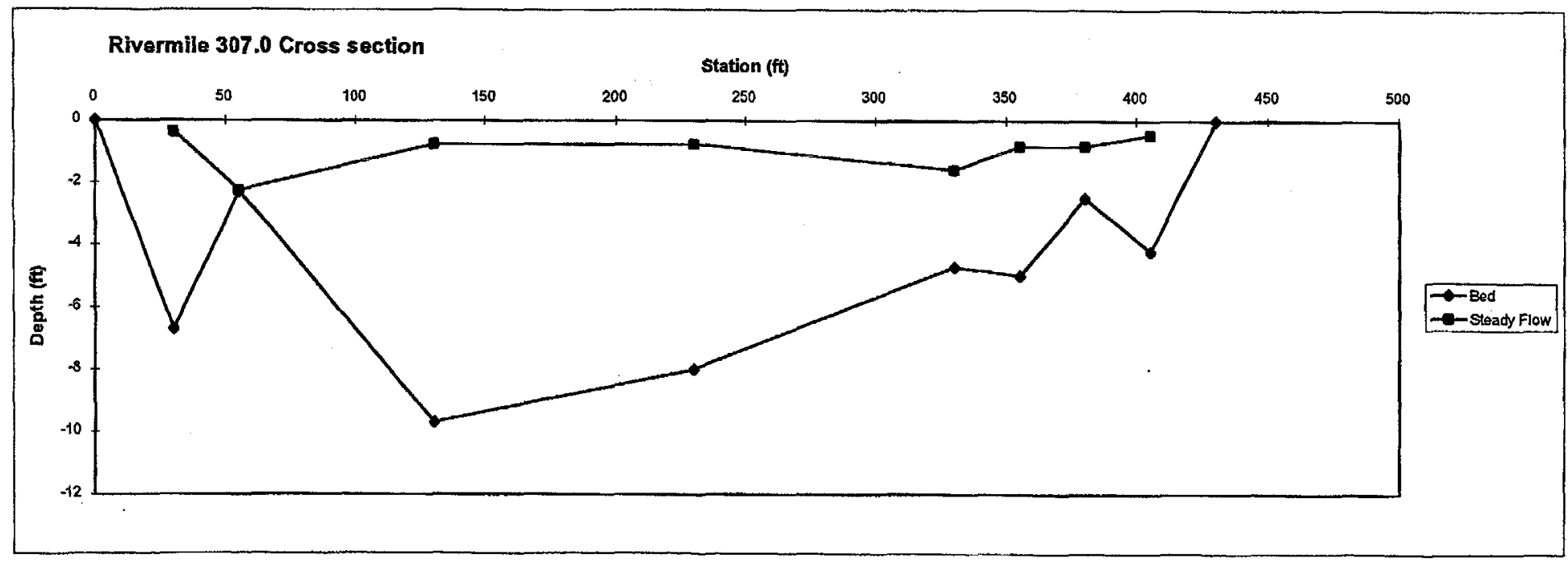


Location: RM 308.2 At poleline across river, opposite Dinosaur Monument employee housing.

During Steady Flow Period @ 1125 hr 1/24/97

Following Peaking @ 1100 hr 1/29/97

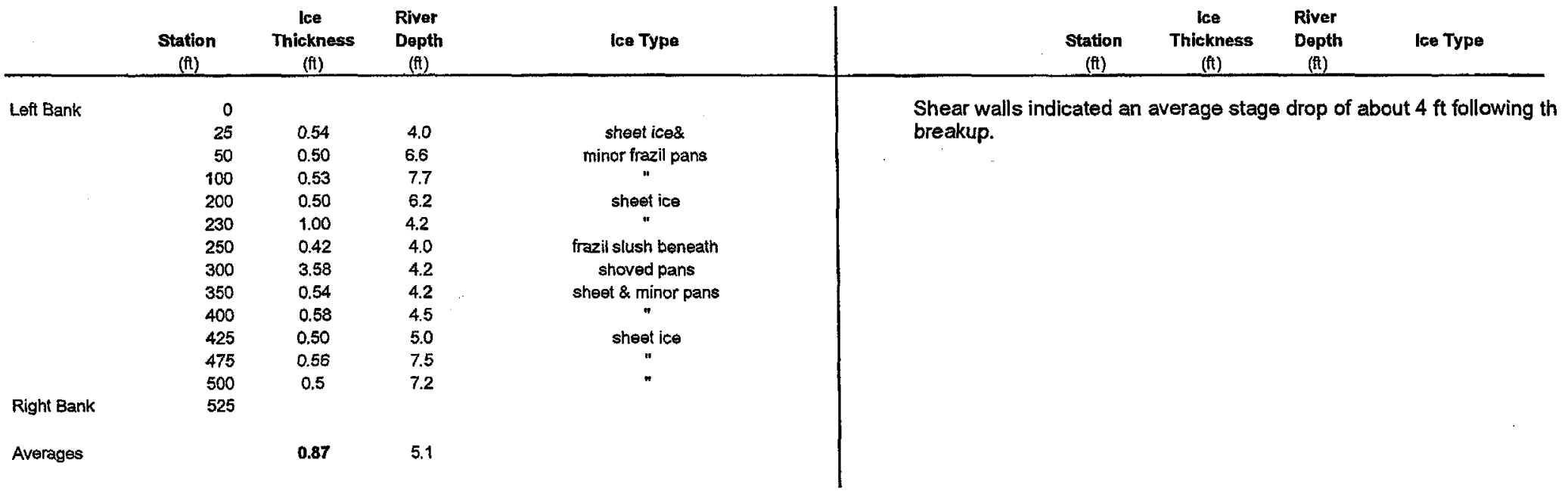

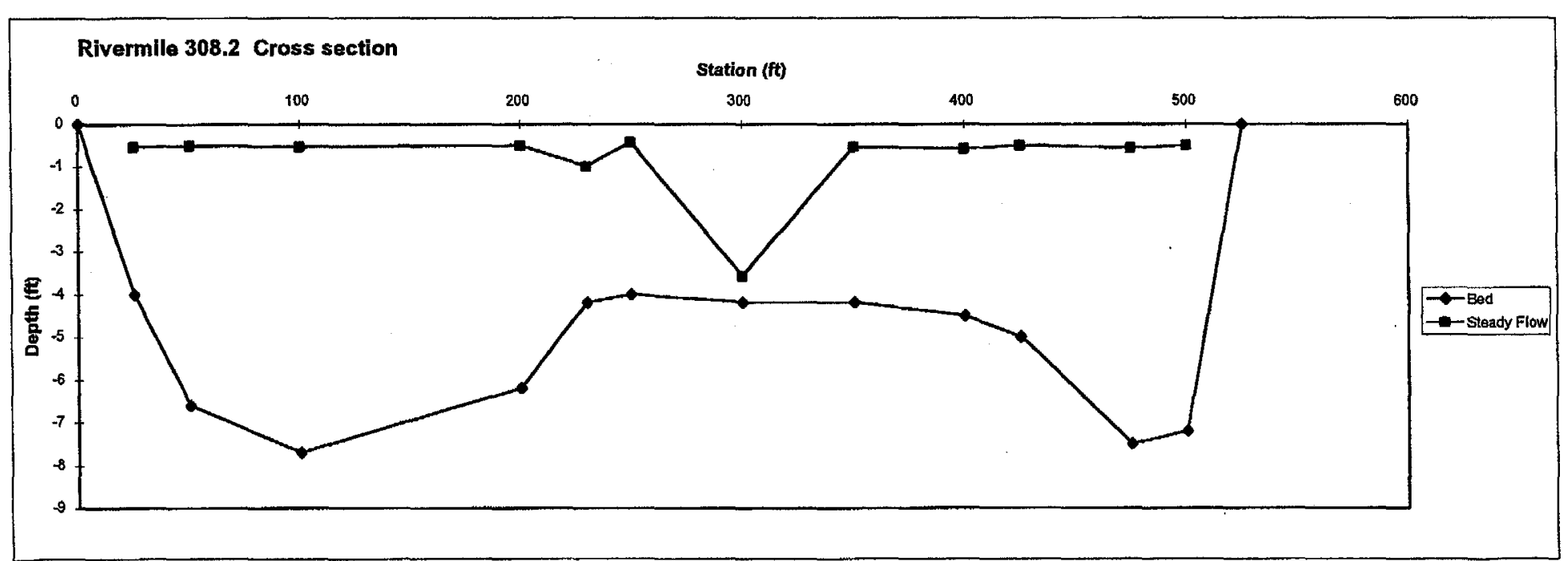



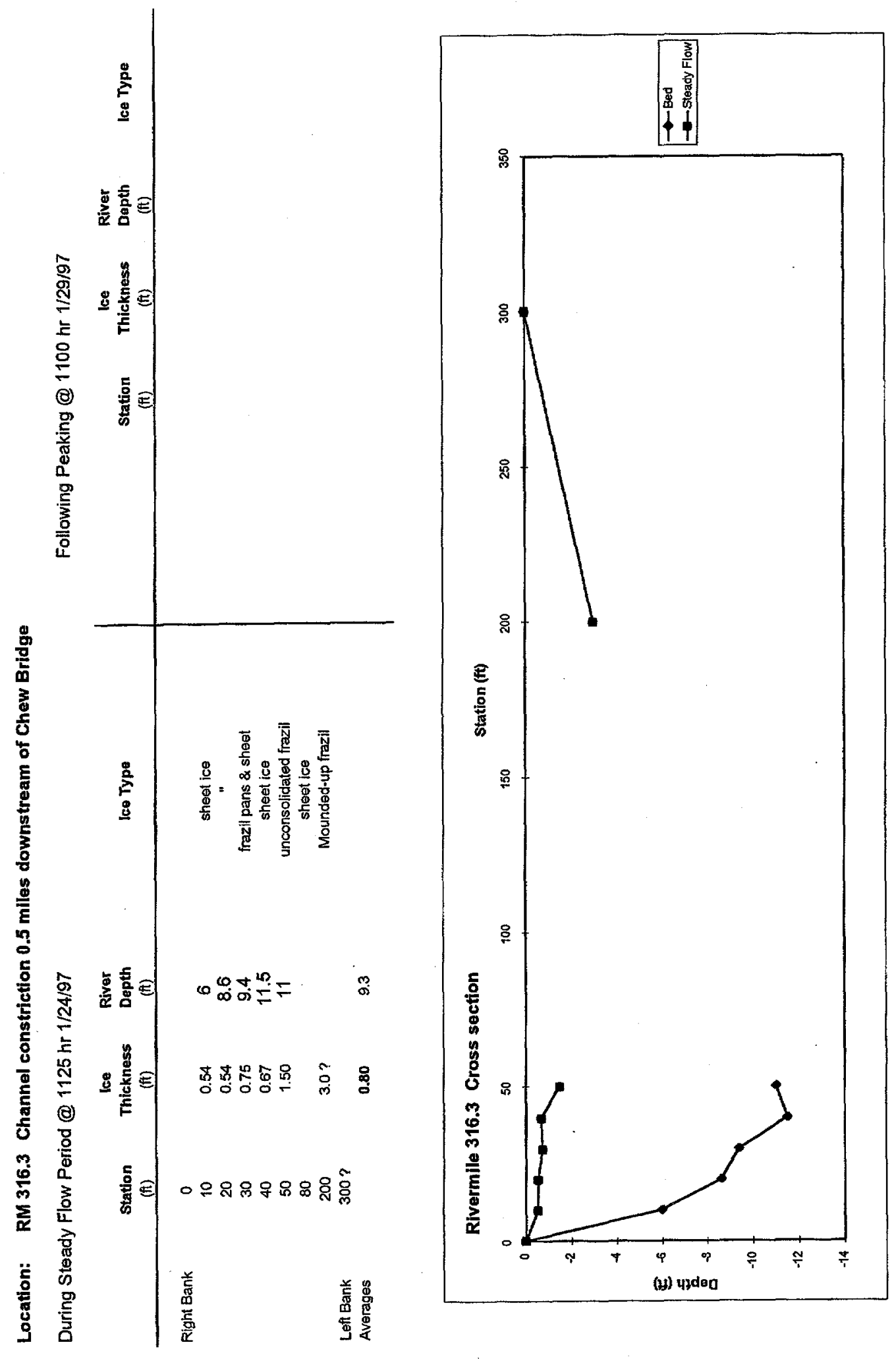